\title{
Zentrum
}

für Biodiversität und nachhaltige Landnutzung

Sektion

Biodiversität, Ökologie und Naturschutz

- CENTRE OF BIODIVERSITY AND SUSTAINABLE LAND USE -

SECTION: BIODIVERSITY, ECOLOGY AND NATURE CONSERVATION

\section{The impact of drought and climate warming on Central European broad-leaved mixed forests}

\author{
Dissertation zur Erlangung des Doktorgrades \\ der mathematisch-naturwissenschaftlichen Fakultäten \\ der Georg-August-Universität Göttingen
}

vorgelegt von

Jorma Zimmermann

aus Kirchheimbolanden 

Betreuungsausschuss

Prof. Dr. Christoph Leuschner, Abteilung Pflanzenökologie und Ökosystemforschung, Universität Göttingen

Prof. Dr. Markus Hauck, Abteilung Pflanzenökologie und Ökosystemforschung, Universität Göttingen

Dr. Choimaa Dulamsuren, Abteilung Pflanzenökologie und Ökosystemforschung, Universität Göttingen

Mitglieder der Prüfungskommission

Referent: Prof. Dr. Christoph Leuschner, Abteilung Pflanzenökologie und

Ökosystemforschung, Universität Göttingen

Korreferent: Prof. Dr. Markus Hauck, Abteilung Pflanzenökologie und Ökosystemforschung, Universität Göttingen

Weitere Mitglieder der Prüfungskommission

Prof. Dr. Hermann Behling, Abteilung Palynologie und Klimadynamik, Universität Göttingen

Prof. Dr. Erwin Bergmeier, Abteilung Vegetationsanalyse und Phytodiversität, Universität Göttingen

Prof. Dr. Dirk Hölscher, Abteilung Waldbau und Waldökologie der Tropen, Universität Göttingen

Prof. Dr. Holger Kreft, Biodiversity, Macroecology and Conservation Biogeography Group, Universität Göttingen

Tag der mündlichen Prüfung: 09.09.2015 



\section{CHAPTER 1}

$\begin{array}{lr}\text { General Introduction } & 9\end{array}$

Forests in the course of climate warming $r$

Dendrochronology and climate change study 12

$\begin{array}{lr}\text { Study objectives and area } & 13\end{array}$

$\begin{array}{lr}\text { References } & 17\end{array}$

\section{CHAPTER 2}

Climate warming-related growth decline affects Fagus sylvatica, but not other broad-leaved tree species in Central European mixed forests $\quad 19$

\begin{tabular}{lr} 
Abstract & 21 \\
\hline
\end{tabular}

$\begin{array}{lr}\text { Introduction } & 22\end{array}$

$\begin{array}{lr}\text { Material and methods } & 23\end{array}$

$\begin{array}{lr}\text { Results } & 28\end{array}$

$\begin{array}{lr}\text { Discussion } & 31\end{array}$

$\begin{array}{lr}\text { References } & 40\end{array}$

\section{CHAPTER 3}

60-yr record of stem xylem anatomy and related hydraulic modification under reduced precipitation in ringand diffuse-porous temperate broad-leaved tree species

Summary

Introduction

$\begin{array}{lr}\text { Material and methods } & 51\end{array}$

$\begin{array}{lr}\text { Results } & 55\end{array}$

$\begin{array}{lr}\text { Discussion } & 63\end{array}$

$\begin{array}{lr}\text { Conclusions } & 67\end{array}$

$\begin{array}{lr}\text { Supplementary material } & 69\end{array}$

$\begin{array}{lr}\text { References } & 71\end{array}$

\section{CHAPTER 4}

Drought alters the competitive hierarchy within tree populations and among different species in temperate broad-leaved mixed forests $\quad 77$

$\begin{array}{lr}\text { Abstract } & 79\end{array}$

$\begin{array}{lr}\text { Introduction } & 80\end{array}$

$\begin{array}{lr}\text { Material and methods } & 82\end{array}$

$\begin{array}{lr}\text { Results } & 85\end{array}$

$\begin{array}{lr}\text { Discussion } & 91\end{array}$

$\begin{array}{lr}\text { Conclusions } & 95\end{array}$

$\begin{array}{lr}\text { References } & 96\end{array}$

\section{CHAPTER 5}

$\begin{array}{lr}\text { Synthesis } & 101\end{array}$

The impact of drought and climate warming on Central European mixed forests 103

Predicting the future development of Central European mixed forest stands 106

$\begin{array}{lr}\text { References } & 110\end{array}$ 



\section{List of abbreviations}

$\begin{array}{ll}\text { A }_{\text {lumen }} & \text { Lumen area } \\ \text { BAI } & \text { Basal area increment } \\ D & \text { Vessel diameter } \\ D_{\mathrm{h}} & \text { Hydraulically weighted vessel diameter } \\ \text { DBH } & \text { Diameter at breast height } \\ \text { EPS } & \text { Expressed population signal } \\ \text { GL } & \text { Gleichläufigkeit } \\ \text { IPCC } & \text { Intergovernmental Panel on Climate Change } \\ K_{\mathrm{h}}^{\text {theo }} & \text { Theoretical hydraulic conductivity } \\ K_{\text {ann }} & \text { Annual conductivity } \\ K_{\mathrm{p}} & \text { Potential conductivity } \\ \text { PET } & \text { Potential evapotranspiration } \\ \text { Rs } & \text { Resilience } \\ \text { SEA } & \text { Superposed epoch analysis } \\ \text { SPEI } & \text { Tree-ring width } \\ \text { VDW } & \text { Vessel density }\end{array}$



Chapter 1

General Introduction 



\section{Forests in the course of climate warming}

Forests provide a wide margin of substantial ecological and economic services, including climate regulation, water and soil conservation, timber and food production as well as being a key component of biodiversity. Less tangible but equally important are the aesthetic and sociocultural services to societies across the world. Those services need a well-functioning ecosystem to be provided reliably and while disturbances are certainly an important part of forest dynamics, they can also lead to a breakdown of a forest ecosystem and a loss of the provided services.

An increasing number of studies from all around the world report cases of tree mortality and die-offs triggered by drought and increasing temperatures (Allen et al. 2010). At the same time climate projections of the Intergovernmental Panel on Climate Change (IPCC 2013) predict a further increase in temperatures combined with an increasing frequency and severity of extreme droughts in some regions. Thus, one of the grand challenges for ecologists will be to examine how forest ecosystems are affected by and response to drought, to predict the consequences of the expected climatic changes on forests (Bonan 2008).

While Europe is among the best documented areas in the world regarding the impact of drought and increasing temperatures on forest ecosystems (Allen et al. 2010), there are still a wide range of uncertainties. It exists little knowledge on species specific response to drought and heat (regulation of water potentials, carbohydrate storage, changes in phenology), leading to an ongoing discussion to which extent climate warming will affect individual species and forest ecosystem in general. A prominent example in this context is Fagus sylvatica, the naturally most abundant species in Central Europe (Ellenberg and Leuschner 2010). Regularly found drought and temperature sensitive (Jump et al. 2006; Piovesan et al. 2008; Köcher et al. 2009; Scharnweber et al. 2011), it is often thought to suffer strongly from the expected changes in climate, whereas others expect it to be relatively weak affected, due to high plasticity and adaptability (Rennenberg et al. 2004; Ammer et al. 2005; Bréda et al. 2006; Geßler et al. 2007; Kölling et al. 2007). Through its outstanding role it is of crucial importance to understand how F. sylvatica is affected by drought and increasing temperatures in comparison to co-occurring species (e.g. Acer and Quercus species, Fraxinus excelsior) to predict the future development of Central European forest ecosystems and develop according strategies for silvicultural practice. Increasing drought exposure could alter the competitive hierarchy between F. sylvatica and other more drought tolerant tree species resulting in shifts in tree species composition in the natural forest vegetation. Modeling and observational studies indicate that the composition of temperate mixed forests may indeed shift after 
relatively small change in precipitation and/or after severe drought events (Bugmann et al. 1997; Lindner et al. 2010; Cavin et al. 2013). The identification and comparison of species specific response to drought and how tree and ecosystem characteristics control individual thresholds to drought provide an important basis for the prediction of forest ecosystem development under a changing climate.

\section{Dendrochronology and climate change study}

Dendrochronology, the study of tree-ring variation, was founded by the astronomer Andrew Ellicott Douglass in the early $20^{\text {th }}$ century, who made the observation that tree-rings of various trees had the same temporal variation pattern. Interested in solar output variation, he speculated that the study of tree-ring variation might yield useful information about past climate and solar variation (Sheppard et al. 2002). Since then many researchers developed and improved the method and tools of dendrochronology to reconstruct climate. In return, climate is used as explanation for changes in tree-ring formation and as a predictor of future tree-ring growth. By now dendrochronology has become an important part of climatology and results are commonly cited by the IPCC (Hughes 2002).

There are several reasons that make dendrochronology an excellent tool to investigate how different species are affected by climatic changes and to predict how those changes may affect forest ecosystems. During their whole life - that can be several centuries long - trees record ecological and climatic relevant data in their tree-rings. Such long records are essential for the study of changes in climate and climates impact on the formation of wood and are needed to evaluate possible scenarios for forest ecosystems in the course of climate warming (Fonti et al. 2010). Furthermore increment is an important factor controlling the dominance of an individual, determining intra- and interspecific competiveness, what allows estimating current and future dominance of different tree species and predicting possible shifts in species composition of forest ecosystems.

Closely related to dendrochronology is the anatomical structure of wood that plays an important part in the trees water transport system. A well-functioning water transport system is crucial for a trees productivity and vitality, and has to be efficient under conditions of ample water supply to enable high photosynthetic rates, while being resistant to failure in periods of drought (Hacke and Sperry 2001). The investigation of the stems xylem anatomy allows identifying how a tree species adapt this part of the water transport system to drought, a further important indicator for tree species plasticity and thus, possible shifts in species composition in the course of climate warming. 


\section{Study objectives and area}

The focus of this study should be to identify and compare the drought sensitivity of cooccurring broad-leaved tree species and how changes in climate may affect the future development of Central European mixed forests. Five broadleaved tree species were investigated: the three diffuse-porous species Fagus sylvatica L. (European beech), Acer pseudoplatanus L. (sycamore maple) and Acer platanoides L. (Norway maple) and the two ring-porous species Quercus petraea Matt. Liebl. (sessile oak) and Fraxinus excelsior L. (European ash). These species were selected because all are moderately or highly important for forestry and may represent different drought response strategies.

As already mentioned, F. sylvatica is the naturally most abundant and one of the economic most important tree species in Central Europe. It achieves its dominance through a very high shade tolerance, combined with high photosynthetic and water use efficiency (Roloff and Schütt 2006). This dominance is kept over a wide amplitude of climatic and edaphic growing conditions and is only lost at extreme sites. One of the limiting factors are, however, extended drought periods that have been found to cause growth decline and die-offs in this species (Jump et al. 2006; Piovesan et al. 2008).

A. pseudoplatanus is a common secondary tree species in Central European forests that is usually dominated by F. sylvatica and would naturally only occur at specific sites, but is often promoted by foresters because its wood is one of the most valuable in Central Europe (Roloff and Schütt 2006). It has very high growth rates in its youth that are slowed drastically under shade conditions and can even stop for several years ("Oskar-Syndrom”), but can quickly be restored to fill opening gaps. Like F. sylvatica, A. pseudoplatanus requires good water supply and in addition high base saturation for satisfactory growth.

A. platanoides is the less demanding of the two Acer species and possesses a relatively high drought resistance, but has a need for warmth and is thus found rather under continental climate conditions (Roloff and Schütt 2006). Its limited height increment and high light demand makes it a weak competitor that is rarely found in Central European forests. It is the economic least important species of the ones investigated in this study and also the one with least data available about it. This species was primarily included to get a picture of the different characteristics and reactions between a drought resistant continental species and a rather water demanding Atlantic species (A. pseudoplatanus) of the same genera.

Q. petraea is one of the two widespread Quercus species in Central Europe, with Q. robur being the second. Both species cannot compete with F. sylvatica except for dry (Q. petraea) or (periodically) wet (Q. robur) sites. Yet, they are often promoted by foresters, being 
amongst the economic most important tree species (Roloff and Schütt 2006). In the course of climate warming Q.petraea is thought to be one of the benefiting species, as increased drought may increase its competiveness towards F. sylvatica (Leuzinger et al. 2005; Friedrichs et al. 2009; Scharnweber et al. 2013).

F. excelsior has a wide amplitude regarding water supply and grows on periodically wet as well as shallow dry sites (Roloff and Schütt 2006). Its high shade tolerance and height increment in the youth is quickly lost with increasing age where it becomes light demanding, a fact that makes this species also unable to compete with $F$. sylvatica. While it does transpire high amounts of water if available, it is insensitive to drought (Köcher et al. 2009; Scherrer et al. 2011). However, its future existence is threatened due to the recently appearing dieback across Europe (Pautasso et al. 2013).

The study was carried out in three broad-leaved mixed forests in the Triassic uplands of south-western Saxony-Anhalt and northern Thuringia in central Germany. This area is situated in the transition zone between a sub-oceanic climate in the west and a more subcontinental climate in the east in the rain shadow of Harz Mountains. F. sylvatica comes close to its drought-induced limit in this region (Ellenberg and Leuschner, 2010) and the species often co-occurs with broad-leaved trees of the genera Quercus, Acer, Tilia, Fraxinus and Carpinus, which are thought to be more drought-tolerant than Fagus (Köcher et al., 2009; Scherrer et al., 2011). The three stands are located between the villages of Keula and Wettelrode along a 50 km-long line in West-East direction (Figure 1.1).

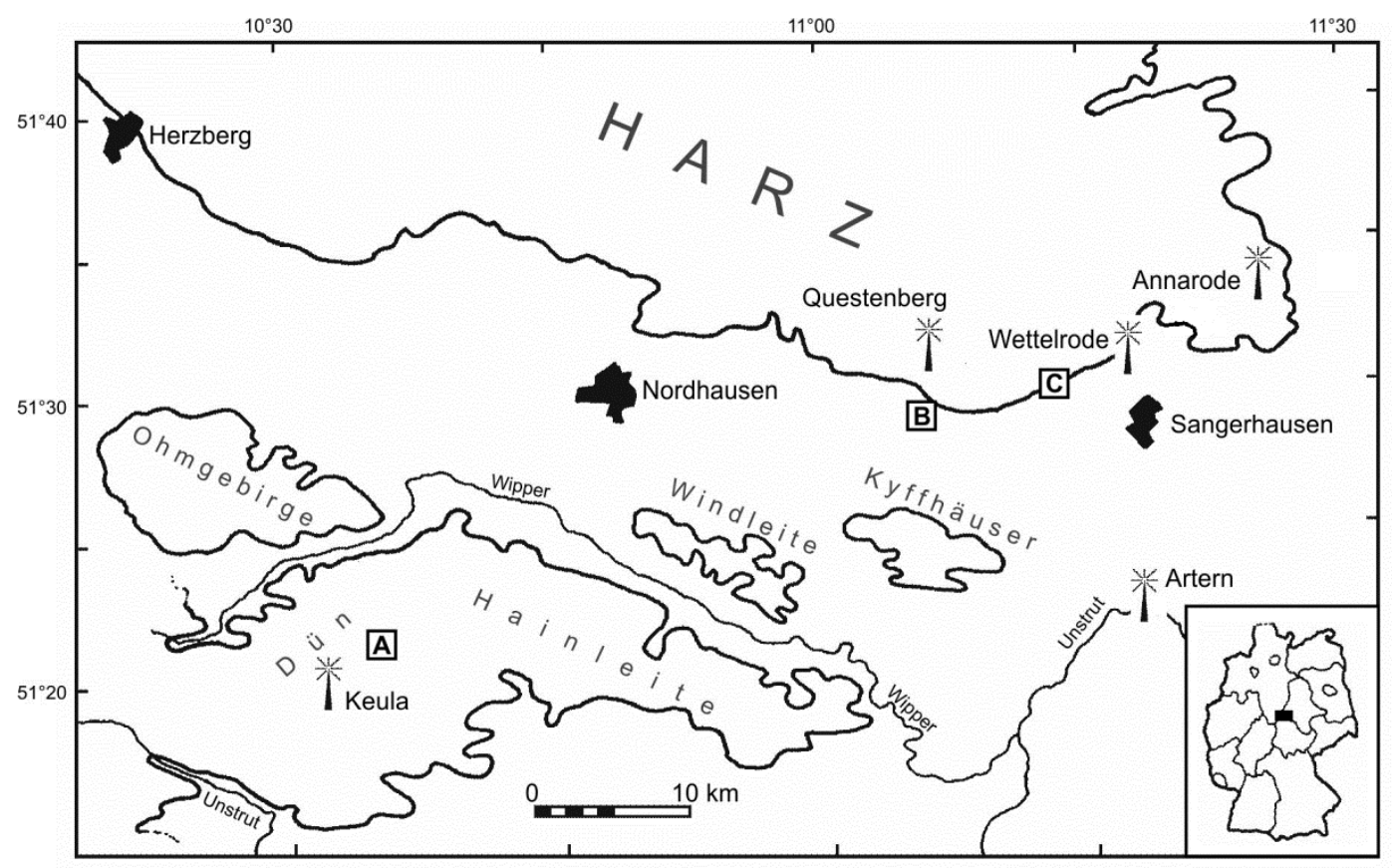

Figure 1.1: Study region with location of the three investigated forests (stand A: Hainleite; stand B: Roßla; stand C: Großleinungen) and position of weather stations (tower symbols with names). 
Table 1.1: Physiographic characteristics of the three forests studied in Central Germany.

\begin{tabular}{lccc}
\hline & Stand A & Stand B & Stand C \\
\hline Location & Hainleite & Roßla & Großleinungen \\
Coordinates & $51^{\circ} 23^{\prime} \mathrm{N}$ & $51^{\circ} 29^{\prime} \mathrm{N}$ & $51^{\circ} 30^{\prime} \mathrm{N}$ \\
Elevation (m a.s.l.) & $10^{\circ} 44^{`} \mathrm{E}$ & $11^{\circ} 04^{`} \mathrm{E}$ & $11^{\circ} 13^{\prime} \mathrm{E}$ \\
Aspect & $400-450$ & $300-350$ & $250-300$ \\
Inclination ( ${ }^{\circ}$ ) & North & North & North \\
Bedrock type & $5-10$ & $5-10$ & $20-30$ \\
Soil texture & Limestone & Pelite rock & Limestone/ \\
Soil type & & & Igneous rock \\
Soil depth (cm) & Silty clayey loam & Silty clay & Silty clayey loam/ \\
Weather station & Cambisol & Vertic Cambisol & Cambisol \\
\multicolumn{1}{c}{ Elevation (m a.s.l.) } & 90 & $>100$ & $80 />100$ \\
\multicolumn{1}{c}{ Recorded since } & Keula & Questenberg & Wettelrode \\
$\quad$ Precipitation (mm y ${ }^{-1}$ ) & 430 & 290 & 295 \\
\hline & 1951 & 1952 & 1969 \\
\hline
\end{tabular}

The uplands show a small-scale heterogeneity in climate and geology with two stands on Triassic limestone and one on pellite rock (VFS, 2005). Located at $250-450 \mathrm{~m}$ elevation, the stands receive 685 to $590 \mathrm{~mm} \mathrm{y}^{-1}$ of precipitation (Deutscher Wetterdienst, Offenbach, Germany), covering the transition from a sub-oceanic climate (stand A) to a summer-drier sub-continental climate (stand C). The stands had tree ages of 100 years or older and were exposed to northern direction. Despite the differences in bedrock, the three stands stocked on similar soils which were all classified as Cambisols in a broader sense and had a silty to clayey soil texture (table 1.1).

For each species up to 20 trees per stand were sampled at breast height $(1.3 \mathrm{~m})$ with an increment borer of $5.15 \mathrm{~mm}$ inner diameter (Hagloef, Sweden). In addition the neighborhood of every target tree was recorded, including species identity, diameter at breast height (DBH) and tree height of every surrounding tree. The collected data was used to analyze (1) the response of tree-ring width to drought and changes in climate (2) how the xylem anatomy is adjusted to reduced water availability and (3) to investigate how the climate sensitivity of tree species is affected by tree characteristics and neighborhood diversity and identity. 
General study aims were to:

- compare the drought sensitivity and the adaption potential to changes in climate of the investigated species and to define species specific thresholds to drought more precisely,

- estimate possible shifts in the species composition of Central Europena mixed forest stands in the course of climate warming through changes in the competitive hierarchy,

- identify the role of neighbourhood diversity for the drought resistance of a tree species and if certain species complement each other exceptionally well in regard to drought resistance.

The results should be a valuable contribution to predict the development of Central European forests under a warmer and drier climate as well as suggestions how silvicultural practice may enhance the drought resistance of forest ecosystems. 


\section{References}

Allen CD, Macalady AK, Chenchouni H, Bachelet D, McDowell N, Vennetier M Kitzberger T, Rigling A, Breshears DD, Hogg EH, Gonzalez P,Fensham R, Zhang Z, Castro J, Demidova N, Lim JH, Allard G, Running SW, Semerci A, Cobb N. 2010. A global overview of drought and heat-induced tree mortality reveals emerging climate change risks for forests. Forest Ecology and Management 259: 660-684.

Ammer C, Albrecht L, Borchert H, Brosinger F, Dittmar C, Elling W, Ewald J, Felbermeier B, von Gilsa H, Huss J, Kenk G, Kolling C, Kohnle U, Meyer P, Mosandl R, Moosmayer HU, Palmer S, Reif A, Rehfuess KE, Stimm B. 2005. Future suitability of beech (Fagus sylvatica L.) in Central Europe: Critical remarks concerning a paper of Rennenberg et al. (2004). Allgemeine Forst und Jagdzeitung 176: 60-67.

Bréda N, Huc R, Granier A, Dreyer E. 2006. Temperate forest trees and stands under severe drought : a review of ecophysiological responses, adaptation processes and long-term consequences. Annals of Forest Science 63: 625-644.

Bonan BG. 2008. Forests and Climate Change: Forcings, Feedbacks, and the Climate Benefits of Forests. Science 320: 1444-1449.

Bugmann H. 1997. Sensitivity of forests in the European Alps to future climatic change. Climate Research 8: 35-44.

Cavin L, Mountford EP, Peterken, GF, Jump AS, Whitehead D. 2013. Extreme drought alters competitive dominance within and between tree species in a mixed forest stand. Functional Ecology 27: 1424-1435.

Ellenberg H, Leuschner C. 2010. Vegetation Mitteleuropas mit den Alpen in ökologischer, dynamischer und historischer Sicht. 6th ed. Stuttgart: Ulmer.

Fonti P, Arx G, García-González I, Eilmann B, Sass-Klaassen U, Gärtner H, Eckstein D. 2010. Studying global change through investigation of the plastic responses of xylem anatomy in tree rings. New Phytologyst 185: 42-53.

Friedrichs DA, Trouet V, Büntgen, Frank DC, Esper J, Neuwirth B, Löffler J. 2009. Speciesspecific climate sensitivity of tree growth in Central-West Germany. Trees 23: 729-739.

Geßler A, Keitel C, Kreuzwieser J, Matyssek R, Seiler W, Rennenberg H. 2007. Potential risks for European beech (Fagus sylvatica L.) in a changing climate. Trees - Structure and Function 21: 1-11.

Hacke UG, Sperry JS. 2001. Functional and ecological xylem anatomy. Perspectives in Plant Ecology 4: 97-115.

Hughes MK. 2002. Dendrochronology in climatology - the state of the art. Dendrochronologia 20: 95-116. 
IPCC. 2013. Summary for Policymakers. In: Climate Change 2013: The Physical Science Basis. Contribution of Working Group I to the Fifth Assessment Report of the Intergovernmental Panel on Climate Change. Stocker TF, Qin D, Plattner GK, Tignor M, Allen SK, Boschung J, Nauels A, Xia Y, Bex V, Midgley PM, editors.

Jump AS, Hunt JM, Penuelas J. 2006. Rapid climate change-related growth decline at the southern range edge of Fagus sylvatica. Global Change Biology: 2163-2174.

Köcher P, Gebauer T, Horna V. 2009. Leaf water status and stem xylem flux in relation to soil drought in five temperate broad-leaved tree species with contrasting water use strategies. Annals of Forest Science 66: 101.

Kölling C, Zimmermann L, Walentowski H. 2007. Klimawandel: Was geschieht mit Buche und Fichte? AFZ/Der Wald 62: 584-588.

Leuzinger S, Zotz G, Asshoff R, Körner C. 2005. Response of decidious forest trees to severe drought in Central Europe. Tree Physiology 25: 641-650.

Lindner M, Maroschek M, Netherer S, Kremer a, Barbati a, Garcia-Gonzalo J, Seidl R, Delzon S, Corona P, Kolstrom M, Lexer M, Marchetti M. 2010. Climate change impacts, adaptive capacity, and vulnerability of European forest ecosystems. Forest Ecology and Management 259: 698-709.

Pautasso M, Aas G, Queloz V, Holdenrieder O. 2013. European ash (Fraxinus excelsior) dieback - A conservation biology challenge. Biological Conservation 158: 37-49.

Piovesan G, Biondi F, Di Fillipo A, Maugeri M. 2008. Drought-driven growth reduction in old beech (Fagus sylvatica L.) forests of the central Apennines, Italy. Global Change Biology 14: 1265-1281.

Rennenberg H, Seiler W, Matyssek R, Gessler A, Kreuzwieser J. 2004. European beech (Fagus sylvatica L.)-a forest tree without future in the south of Central Europe? Allgemeine Forst und Jagdzeitung 175: 210-224.

Roloff A, Schütt P. 2006. Enzyklopädie der Holzgewächse, Handbuch und Atlas der Dendrologie. Ecomed Biowissenschaften, Einbändige Sonderausgabe ersch. U.d.T.: Enzyklopädie der Sträucher Edn. Landsberg am Lech.

Sheppard PR, Comrie AC, Packin GD, Angersbach K. Hughes MK. 2002. The climate of the US Southwest. Climate Research 21: 219-238.

Scharnweber T, Manthey M, Criegee C, Bauwe A, Schröder A, Wilmking M. 2011. Drought matters - Declining precipitation influences growth of Fagus sylvatica L. and Quercus robur L. in north-eastern Germany. Forest Ecology and Management 262: 947-961.

Scherrer D, Bader KFB, Körner C. 2011. Drought-sensitivity ranking of deciduous tree species based on thermal imaging of forest canopies. Agriculture and Forest Meteorology 151: 1632-1640.

VFS. 2005. Waldökologische Naturräume Deutschlands. Mitteilungen des Vereins für Forstliche Standortskunde und Forstpflanzenzüchtung 43. 


\section{Chapter 2}

\section{Climate warming-related growth decline affects Fagus sylvatica, but not other broad-leaved tree species in Central European mixed forests}

Jorma Zimmermann • Markus Hauck • Choimaa Dulamsuren • Christoph Leuschner

Published in

ECOSYSTEMS 2015, 18:560-572

DOI: 10.1007/s10021-015-9849-x 



\begin{abstract}
Climate warming is predicted to extend the duration and enhance the severity of summer droughts in Central Europe, what may pose a serious risk to forest productivity and forest health. Fagus sylvatica (European beech), the most abundant tree species of Central Europe's natural forest vegetation and one of the key species in forestry, is thought to be particularly vulnerable to drought.

Here, we present a dendrochronological analysis in three mixed temperate broad-leaved forests along a precipitation gradient with the aim of comparing the climatic response of radial growth of F. sylvatica with the performance of four co-existing species (Acer pseudoplatanus, A. platanoides, Quercus petraea, Fraxinus excelsior). We hypothesized that Fagus is the most drought-sensitive of the five species, which implies that it could lose its competitive advantage at drier sites in the course of climate warming. In support of this hypothesis, we found for F. sylvatica in all stands exhibited an increase in the number of negative pointer years and a decrease in radial increment in the driest stand since $\sim 1980$, in parallel to increasing summer temperatures and drought intensity. Such a response was missing in the other four species and may point to shifts in the competitive hierarchy in these mixed forests under a future warmer climate.

We conclude that Central Europe's forestry sector should consider carefully the risk of failure of beech in regions with relatively low and decreasing summer precipitation.
\end{abstract}

Key words: climate warming, competition, dendrochronology, drought, European beech, radial growth, mixed forest, forest dynamics 


\section{Introduction}

During the last 100 years, summer rainfall has decreased in large parts of eastern and central Germany by up to $60 \mathrm{~mm} \mathrm{y}^{-1}$ (Schönwiese and Janoschitz 2008) and is predicted to further decline with climate warming until the end of the $21^{\text {st }}$ century (Spekat et al. 2007; Jacob 2009), although recent projections are less distinct (IPCC 2013). Reduced soil water availability in conjunction with a rising atmospheric demand for water vapor will expose the forests to longer and more severe drought periods. Moreover, climate change scenarios predict that extreme drought events, as happened in 1959, 1976 and 2003 in Central Europe, will occur more frequently in the decades to come (Schär et al. 2004). This development is alarming because the dominant tree species of Central European natural forest vegetation, European beech (Fagus sylvatica L.), is thought to be relatively drought sensitive (Rennenberg et al. 2004; Köcher et al. 2009; Leuschner 2009). In support of this assumption, several studies from southern Europe show a decline in beech growth and local dieback at the species' southern range limit (Jump et al. 2006; Piovesan et al. 2008). However, recent growth reductions were also recorded in the drier regions of north-eastern Germany not far from the northern and eastern range limits (Scharnweber et al. 2011). Increasing drought exposure could alter the competitive hierarchy between beech and other more drought-tolerant tree species resulting in shifts in tree species composition in the natural forest vegetation, as observed by Cavin et al. (2013) in a mixed forest stand.

Dendrochronology is a well-suited tool for analyzing the climate sensitivity of tree growth and the long-term impact of precipitation and temperature trends on forest productivity and vitality. When applied to mixed forests, species responses can be compared and predictions about future competitive hierarchies become possible. Here, we present the results of a dendrochronological study on five coexisting broad-leaf tree species in three mixed forests with varying precipitation regimes in Central Germany. The stands are located along a precipitation gradient ( 690 to $590 \mathrm{~mm} \mathrm{y}^{-1}$ ) with the dry end being close to the assumed drought limit of beech (Ellenberg and Leuschner 2010).

Our study objectives were (i) to investigate if decreasing precipitation causes a growth depression in F. sylvatica, (ii) to compare the drought sensitivity of the five species under equal growing conditions, (iii) to identify a more precise precipitation threshold for F. sylvatica in the study area, and (iv) to assess how species differences in drought sensitivity and growth performance might alter the competitive hierarchy in the mixed stands in future time. We tested the following hypotheses: (i) F. sylvatica is the most climate-sensitive of the five species, (ii) recent increase in summer drought have already affected radial increment of 
F. sylvatica in dry stands, and (iii) the other four species do not show a similar reduction in radial growth. To our knowledge, this study is the first attempt to analyze the possible impact of climate change-related drought on competitive inter-relationships in relatively species-rich temperate forests using empirical evidence.

\section{Material and methods}

Study area and sampled stands

The study was carried out in three mixed broad-leaved forests in the Triassic uplands of south-western Saxony-Anhalt and northern Thuringia in central Germany (Fig. 2.1a), in the transition zone between a sub-oceanic climate in the West and a more sub-continental climate in the East in the rain shadow of the Harz Mountains. Here, European beech (Fagus sylvatica), the dominant tree species of natural forest vegetation in large parts of Central Europe, comes close to its drought-induced limit (Ellenberg and Leuschner 2010) and the species often co-occurs with broad-leaved trees of the genera Quercus, Acer, Tilia, Fraxinus and Carpinus, which are thought to be more drought-tolerant than Fagus (Köcher et al. 2009; Scherrer et al. 2011). We sampled European beech, sycamore maple (Acer pseudoplatanus L.), Norway maple (Acer platanoides L.), sessile oak (Quercus petraea Matt. Liebl.) and European ash (Fraxinus excelsior L.). These species are moderately or highly important for forestry and may represent different drought-response strategies.

The three stands (A, B and C) are located along a $50 \mathrm{~km}$-long transect in west-east direction at elevations between 450 and 250 m (Fig. 2.1b), which covers a precipitation gradient from 685 to $590 \mathrm{~mm} \mathrm{y}^{-1}$ (Deutscher Wetterdienst, Offenbach, Germany). The gradient represents the assumed transition from a mixed forest in a sub-oceanic climate to a mixed forest under a summer-dry sub-continental climate (Table 2.1).

Stand C was located on a particularly steep slope and showed some heterogeneity in soil depth on either limestone or igneous rock, with beech typically growing on the shallower and oak on the deeper soils. In this stand, wood cores were taken for all species on both soil types. The trees had ages of $\sim 100$ years or older.

\section{Climate data}

In the neighborhood of all three stands, weather stations recording precipitation were available (Table 2.1). Gaps in the precipitation data of Stand B and C were interpolated using data from other stations. 


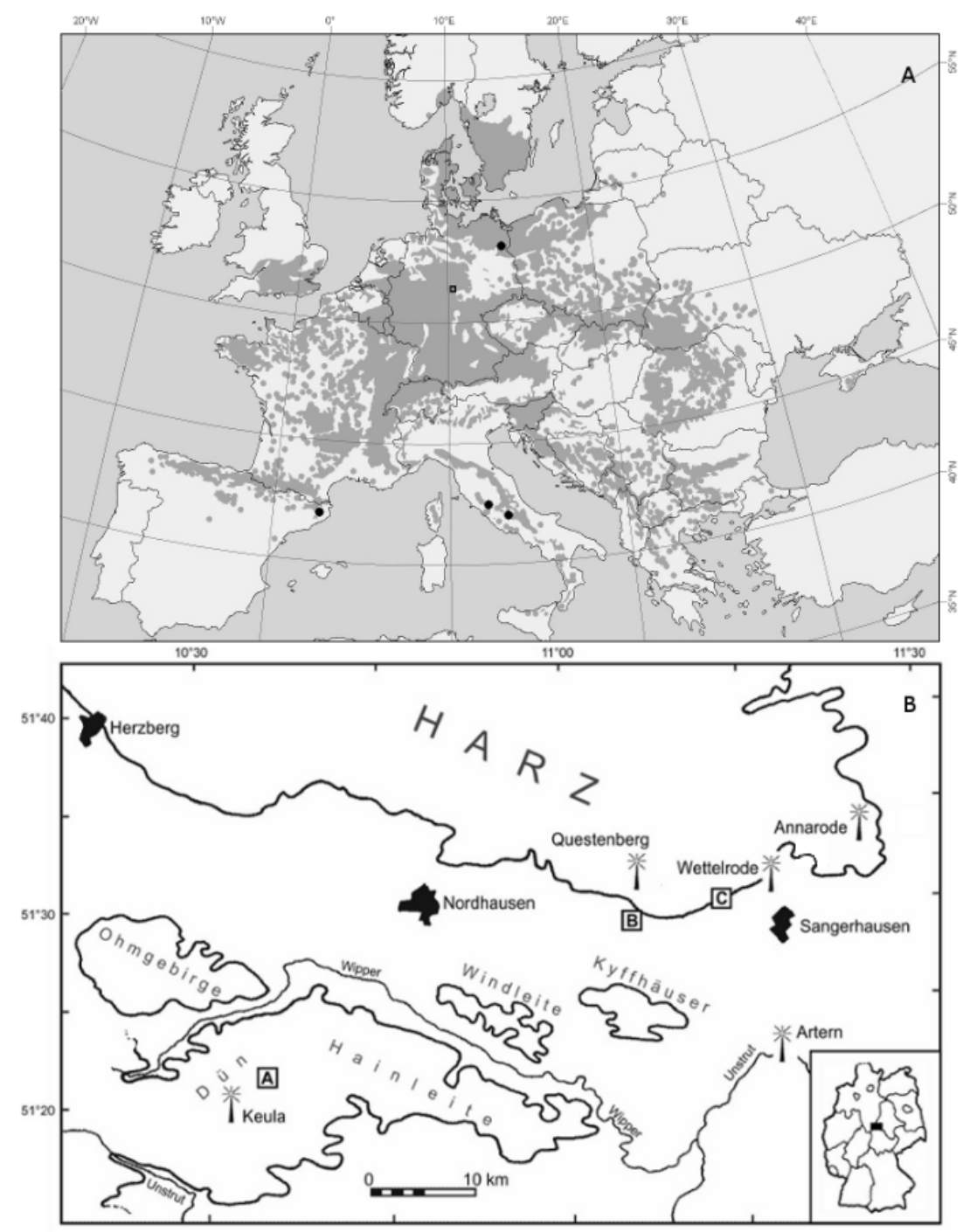

Figure 2.1: (A) Distribution of Fagus sylvatica within Europe (Euforgen 2009, www.euforgen.org, modified). Dots mark the location where a recent growth decline of European beech was found [Montseny Mountains, Spain; Alistair et al. 2006; Apennines, Italy, Piovesan et al. 2008; Mecklenburg-Pommerania, Germany; Scharnweber et al. 2011]. The square indicates the region of the present study. (B) Study region with location of the three investigated forests (stand A: Hainleite; stand B: Roßla; stand C: Großleinungen) and position of weather stations (tower symbols with names).

Drought intensity was quantified with the standardized precipitation evapotranspiration index (SPEI) (Vincente-Serrano et al. 2010). The SPEI was calculated with R software v. 2.15 (R Development Core Team 2012) using the R-package "SPEI" v. 1.6. For the calculation, monthly precipitation and potential evapotranspiration (PET) data were used. PET was calculated with the Thornthwaite method (Thornthwaite 1948) using monthly mean temperature and a correlation coefficient derived from latitude to calculate day length. SPEI was calculated on a monthly timescale using indices with a log-logistic probability distribution and parameter fitting based on unbiased probability-weighted moments. This short time scale was used for identifying short drought episodes, which could affect droughtsensitive tree species on shallow soils. To detect long-term change in summer drought 
intensity in the period 1951-2010, linear regressions between the averaged SPEI index of the months June-August and time (year) were performed.

Table 2.1: Physiographic characteristics of the three forests studied in Central Germany.

\begin{tabular}{lccc}
\hline & Stand A & Stand B & Stand C \\
\hline Location & Hainleite & Roßla & Großleinungen \\
Coordinates & $51^{\circ} 23^{\prime} \mathrm{N}$ & $51^{\circ} 29^{\prime} \mathrm{N}$ & $51^{\circ} 30^{\prime} \mathrm{N}$ \\
Elevation (m a.s.l.) & $10^{\circ} 44^{`} \mathrm{E}$ & $11^{\circ} 04^{`} \mathrm{E}$ & $11^{\circ} 13^{\prime} \mathrm{E}$ \\
Aspect & $400-450$ & $300-350$ & $250-300$ \\
Inclination ( ${ }^{\circ}$ ) & North & North & North \\
Bedrock type & $5-10$ & $5-10$ & $20-30$ \\
Soil texture & Limestone & Pelite rock & Limestone/ \\
Soil type & Igneous rock \\
Soil depth (cm) & Silty clayey loam & Silty clay & Silty clayey loam/ \\
Weather station & Cambisol & Vertic Cambisol & Cambisol \\
\multicolumn{1}{c}{ Elevation (m a.s.l.) } & 90 & $>100$ & $80 />100$ \\
\multicolumn{1}{c}{ Recorded since } & Keula & Questenberg & Wettelrode \\
\multicolumn{1}{c}{ Precipitation (mm y ${ }^{-1}$ ) } & 430 & 290 & 295 \\
\hline
\end{tabular}

\section{Wood core sampling}

From July to October 2011, 18-20 wood cores (one per tree) were collected per species and stand. Due to their lower abundance in the stands, only 11-16 cores of the Acer species could be collected. In stand C, no individuals of F. excelsior were present. All selected trees were part of the upper canopy; a minor exception existed in the case of A. platanoides, where the small number of trees in the stands forced us to select trees in the lower part of the main canopy (max. 2 individuals per stand). Samples were taken at breast height $(1.3 \mathrm{~m})$ with an increment borer of $5 \mathrm{~mm}$ inner diameter (Haglöf, Langsele, Sweden) in the direction where the least influence of tension wood was to be expected. Tree-ring width was measured with a precision of $10 \mu \mathrm{m}$ on a movable object table (Lintab 5, Rinntech, Heidelberg, Germany) using the software TSAP-Win v. 4.67c (Rinntech).

\section{Analysis of tree-ring data}

The tree-ring data were analyzed with TSAP-Win software. Cross-dating was based on the coefficient of agreement (GL, 'Gleichläufigkeit'; Eckstein and Bauch 1969) and $t$-values 
(Baillie and Pilcher 1973). To extract the climate signal, the ring series were standardized using the expression $t_{i}=100 *\left(r_{i} / m_{i}\right)$ with $r_{i}$ being ring width and $m_{i}$ the 5-year moving average in year i. The coherence within the tree-ring chronologies was measured by the expressed population signal (EPS) (Wigley et al. 1984). Chronologies were split into 30-y intervals with a 15-y overlap, and EPS was calculated for each interval. Chronologies were considered reliable as soon as EPS exceeded the 0.85-threshold. EPS was calculated using the R-package ‘Dendrochronology Program Library in R' (dplR) v. 1.5.5 (Bunn 2008).

The year-to-year variability of ring width was expressed as mean sensitivity and calculated over the whole lifespan of the sample trees, as was done for first-order autocorrelation, i.e. the influence of previous year's increment on current year's increment (Fritts 2001). For identifying pointer years, the growth deviation $\delta z_{i}$ (pointer year value) was calculated with the expression $\delta p_{i}=\left(p_{i}-\overline{p_{i}}\right) / \sigma_{c}{ }^{*} 100$ with $\overline{p_{i}}$ being the 5-y moving average of $p_{i}$ and $\sigma_{c}$ the standard deviation (SD) of the entire chronology. A year was defined as pointer year if the difference between $\mathrm{p}_{\mathrm{i}}$ and $\overline{p_{i}}$ was larger than one SD of the chronology. SD was used as indicator because of its independence from differences in sensitivity caused by species or site effects (Bräuning 1999). Only pointer years that occurred during pointer intervals were used for further analysis (Schweingruber et al. 1990). For this study, a pointer interval was defined as an interval where $85 \%$ of the trees of a chronology showed the same growth trend. We applied these strict criteria in order to identify only those years in which increment was most considerable reduced. Since we were primarily interested in drought effects on increment, only negative pointer years were investigated $\left(\delta p_{i}<-100\right)$.

\section{Analysis of climate-growth relationships}

The relations between tree-ring width and climate parameters were calculated according to Guiot (1991) using the R package bootRes v 1.2.3 (Zang and Biondi 2013). The package calculates the response coefficients for 1000 samples drawn randomly with replacement from the calibration set. Significance was tested using the 95\% percentile range method (Dixon 2001). Standardized tree-ring width was related to monthly precipitation totals and temperature means. Analyses were done for the months from previous year's June to current year's September covering the period 1951-2010 for precipitation and 1954-2010 for temperature. To investigate the influence of drought on growth, a superposed epoch analysis (SEA) testing for the mean growth response to the driest summers (SPEI < -1 ) in the period 1954-2010 was calculated using dplR (Bunn 2008). The SEA calculates the significance of departure from the mean for event years and lagged years (superposed epoch), by comparing 
the value of the superposed epoch, to randomly selected epochs, which are selected from the dataset using bootstrap resampling (1000 resamples).

In order to compare the long-term trend of tree-ring widths and climate, time-series were standardized via z-transformation using the formula $\mathrm{z}_{\mathrm{i}}=\left(\mathrm{x}_{\mathrm{i}}-\mu\right) / \sigma$ with $\mathrm{x}_{\mathrm{i}}$ being the value (treering width/temperature) of the actual year, $\mu$ being the mean of the time-series and $\sigma$ being the standard deviation of the time-series.

\section{Statistical analyses}

Arithmetic means \pm SD are presented throughout the paper. All data sets were tested for normal distribution with the Shapiro-Wilk test. Homogeneity of variances was tested with Levene's test. Tukey's HSD test (at normal distribution) or the Mann-Whitney U test was applied to test for significant differences between means. In case of multiple comparisons, the family-wise error rate was corrected with the Holm-Bonferroni method. Statistical analyses were calculated with R 2.15 software. The significance level was set to $\alpha \leq 0.05$. 


\section{Results}

\section{Climate trends}

Annual mean temperature increased in the study region by $1.6 \mathrm{~K}$ from 1954 to $2010\left(\mathrm{R}^{2}=0.29\right.$, $\mathrm{p}<0.001$ ), i.e. by $0.29 \mathrm{~K}$ per $10 \mathrm{y}$. This increase was observed in all seasons except for autumn and was particularly strong in the months February - May and July/August. There was no significant change in annual precipitation, but summer drought intensity, as quantified by the SPEI, also increased from 1954 to 2010 (Fig. 2.2).

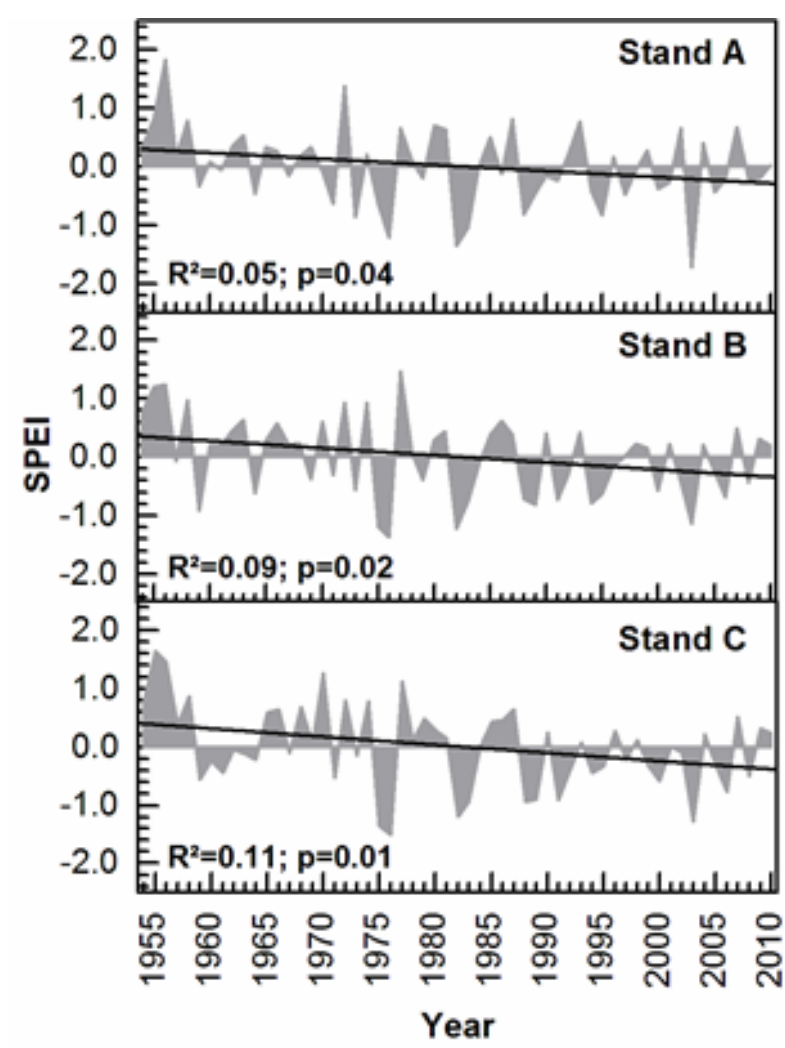

Figure 2.2: Mean standardized precipitation/evapotranspiration index (SPEI) of the summer months (June-August) for the stands A-C in the period 1954-2010. SPEI was calculated after Vincente-Serrano et al. (2010) as the difference between precipitation and potential evapotranspiration. Negative values indicate water deficits. Significant trend lines are indicated.
Tree-ring width and climate response

The mean length of the chronologies varied between 84 and 114 years. However, in the stands A and B the Q. petraea trees were older than the other species (Table 2.2). All chronologies had mean EPS values >0.85; but the 30-y-period, in which EPS exceeded this threshold, varied among species and stands.

The ring-porous species Q.petraea and F. excelsior showed a lower mean sensitivity than the diffuse-porous species; yet, the differences were significant only in the drier stands. First-order autocorrelation was similar for all species and stands.

In general, the inter-annual variation in treering width was very similar among the studied species, while the amplitudes differed (Fig. 2.3). In all stands, mean ring width in the period 1906-2010 was largest in F. sylvatica, but the difference compared to

the other species decreased along the gradient. The loss in beech growth advantage from stand A to $C$ was related to a marked growth reduction in the driest stand C since about 1980, which was not observed in the moister stands A and B. This 30-yr growth decline occurred only in F. sylvatica but not in the other co-occurring species and is closely related to the increasing 
Table 2.2: Statistics of tree-ring data and chronologies; N: number of sampled trees, AGE: mean age at breast height (1.3 m), MRW: mean ring width (1906-2010), MS: mean sensitivity, AC: first order autocorrelation, EPS: expressed population signal. Uppercase letters indicate significant $(\mathrm{p}<0.05)$ differences between species in the same stand. Significant differences between means were tested either with Tukey's HSD test or Mann-Whitney U test.

Species code: FS: Fagus sylvatica, APS: Acer pseudoplatanus, APL: Acer platanoides, QP: Quercus petraea, FE: Fraxinus excelsior

*EPS was slightly below 0.85 for the timespan 1936-1965, but not for 1921-1950 and 1951-1980

\begin{tabular}{cccccccc}
\hline Stand & Species & $\mathbf{N}$ & Age (yr) & MRW (mm) & MS & AC & EPS>0.85 since \\
\hline \multirow{4}{*}{ A } & FS & 20 & 95 & $2.45 \pm 0.45^{\mathrm{a}}$ & $0.24 \pm 0.05^{\mathrm{ac}}$ & $0.61 \pm 0.14^{\mathrm{a}}$ & 1906 \\
& APS & 16 & 95 & $1.95 \pm 0.24^{\mathrm{b}}$ & $0.29 \pm 0.06^{\mathrm{a}}$ & $0.75 \pm 0.1^{\mathrm{b}}$ & $1906^{*}$ \\
& APL & 11 & 84 & $2.16 \pm 0.35^{\mathrm{b}}$ & $0.34 \pm 0.08^{\mathrm{b}}$ & $0.63 \pm 0.13^{\mathrm{ab}}$ & $1921^{*}$ \\
& QP & 20 & 155 & $1.59 \pm 0.33^{\mathrm{c}}$ & $0.23 \pm 0.03^{\mathrm{c}}$ & $0.69 \pm 0.12^{\mathrm{ab}}$ & 1831 \\
& FE & 20 & 96 & $2.11 \pm 0.33^{\mathrm{b}}$ & $0.21 \pm 0.03^{\mathrm{c}}$ & $0.65 \pm 0.13^{\mathrm{ab}}$ & 1921 \\
\hline & FS & 20 & 101 & $2.37 \pm 0.48^{\mathrm{a}}$ & $0.30 \pm 0.06^{\mathrm{a}}$ & $0.57 \pm 0.15^{\mathrm{a}}$ & 1906 \\
& APS & 16 & 114 & $1.94 \pm 0.38^{\mathrm{b}}$ & $0.33 \pm 0.10^{\mathrm{ab}}$ & $0.60 \pm 0.13^{\mathrm{a}}$ & 1891 \\
$\mathbf{3}$ & BPL & 13 & 108 & $1.75 \pm 0.28^{\mathrm{c}}$ & $0.40 \pm 0.07^{\mathrm{b}}$ & $0.71 \pm 0.15^{\mathrm{a}}$ & 1906 \\
& QP & 18 & 123 & $1.91 \pm 0.48^{\mathrm{b}}$ & $0.25 \pm 0.04^{\mathrm{ac}}$ & $0.67 \pm 0.16^{\mathrm{a}}$ & 1861 \\
& FE & 19 & 101 & $2.13 \pm 0.35^{\mathrm{d}}$ & $0.24 \pm 0.04^{\mathrm{c}}$ & $0.57 \pm 0.17^{\mathrm{a}}$ & 1906 \\
\hline & FS & 20 & 103 & $2.15 \pm 0.29^{\mathrm{a}}$ & $0.31 \pm 0.06^{\mathrm{a}}$ & $0.60 \pm 0.14^{\mathrm{a}}$ & 1906 \\
& APS & 14 & 88 & $1.90 \pm 0.36^{\mathrm{b}}$ & $0.36 \pm 0.10^{\mathrm{a}}$ & $0.65 \pm 0.19^{\mathrm{a}}$ & 1921 \\
$\mathbf{C}$ & APL & 11 & 108 & $1.40 \pm 0.21^{\mathrm{c}}$ & $0.38 \pm 0.08^{\mathrm{a}}$ & $0.55 \pm 0.13^{\mathrm{a}}$ & 1906 \\
& QP & 20 & 108 & $1.72 \pm 0.49^{\mathrm{d}}$ & $0.25 \pm 0.04^{\mathrm{b}}$ & $0.69 \pm 0.17^{\mathrm{a}}$ & 1891 \\
\hline
\end{tabular}

temperatures during the growing season (April - September, Fig. 2.4). In the moister stands A and B, F. sylvatica maintained its advantage in radial growth until today. The increment of all species was mostly limited by spring and summer precipitation in the current year, as well as summer temperatures of the current and of the previous year (Fig. 2.5). Regarding precipitation (Fig. 2.5f-j), June had the strongest influence on diameter growth in all species. In all species except for F. excelsior, the temperature of the previous year had a stronger influence on increment than the thermal conditions of the current year (Fig. 2.5a-e). The response of $F$. sylvatica and F. excelsior differed slightly from that of the other species in that spring precipitation was less important while late-summer temperature had a stronger effect than in the other species.

The results of the superposed epoch analysis confirm the negative impact of drought on increment. Summer drought led to increment decreases in the year of the drought or the following year in all species (Fig. 2.6). Especially the diffuse-porous species showed a stronger growth reduction in the year after the drought. While the increment reduction was less pronounced in F. sylvatica at the first two stands, beech showed the strongest reduction of all species at the driest stand C. 


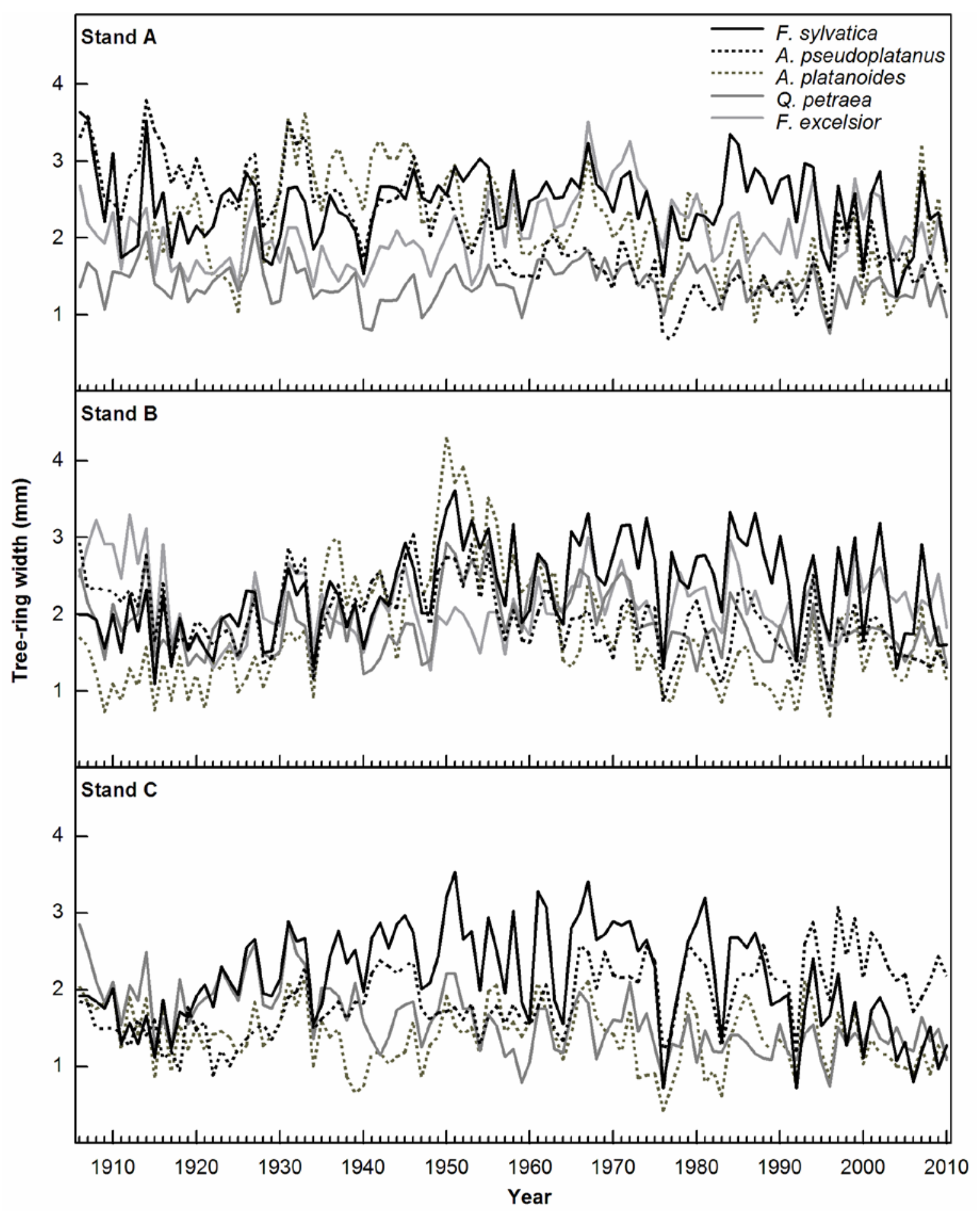

Figure 2.3. Tree-ring chronologies of the five investigated species in the stands A to C. Chronologies start in 1906 where the majority of species present exceeded the EPS threshold of 0.85 (see Table 2.3). The oak trees (Q. petraea) are considerably older than the other species in stand A and B. 
The results of the pointer year analysis match the above-mentioned findings. In general, the number and intensity of pointer years increased toward the drier stands (Fig. 2.7). Typically, negative pointer years manifested in the second of two consecutive dry summers. However, the thermal conditions during droughts played an important role as well. Moderate droughts with high temperatures were more likely to result in growth depressions than stronger droughts with lower temperatures. Another noticeable exception is the

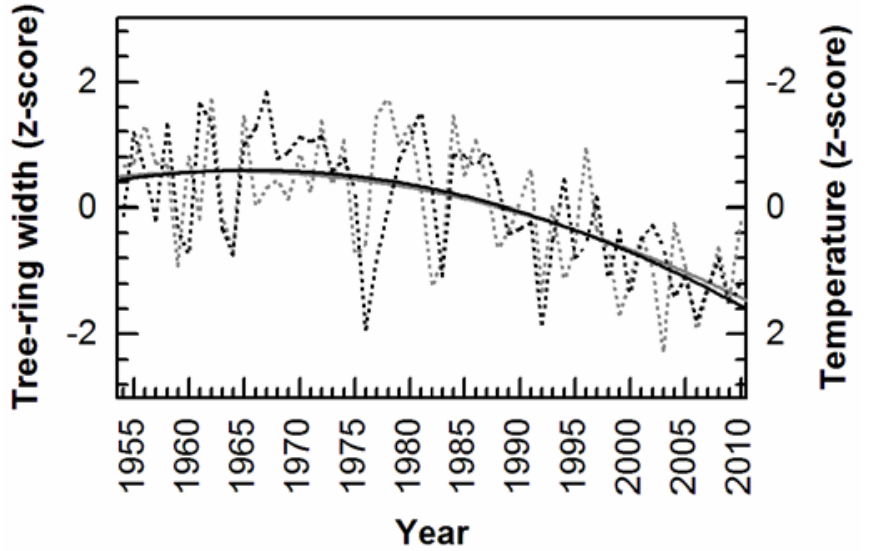

Figure 2.4. Temporal trend of $\mathrm{z}$-transformed tree-ring width of F. sylvatica in stand C (black line) and $\mathrm{z}-$ transformed temperatures during the vegetation period (grey line). For both parameters, quadratic functions were fitted (Tree-ring width: $y=0.4112+0.0276 \mathrm{x}-0.0011 \mathrm{x}^{2}$, $\mathrm{R}^{2}=0.42, \quad \mathrm{p}<0.001$; $\quad$ Temperature: $\mathrm{y}=0.474-$ $0.0184 \mathrm{x}+0.0009 \mathrm{x}^{2}, \mathrm{R}^{2}=0.37, \mathrm{p}<0.001$ ). The temperature axis is inverted to achieve comparability with the treering widths.

negative pointer year 1996, which probably was caused by a long winter with a very cold and dry March. The most consistent negative pointer year related to drought was in all species 1976, which produced a clear signal in F. sylvatica and A. pseudoplatanus in every stand, and in Q. petraea and F. excelsior in two of the three stands. Other negative pointer years, that met the above-mentioned criteria and were visible in several species, include 1983 and 1992. In these years and in 1976, F. sylvatica exceeded all other species with respect to the intensity of the pointer year. Beech was also the only species showing an increase in the frequency of negative pointer years in the recent past, which is consistent with the increment decline in stand C. The highest number of negative pointer years in the 60-yr-period was found in F. sylvatica (5.0; average of stands A-C), followed by Q. petraea (4.3) and F. excelsior (3.5), while A. pseudoplatanus and A. platanoides had the lowest numbers (2.7).

\section{Discussion}

\section{Identifying a precipitation limit for Fagus sylvatica}

Our results show a strong decline in radial stem increment of F. sylvatica in the driest stand since about the 1980s. In this stand with a mean annual precipitation of $\sim 590 \mathrm{~mm}$, mean diameter growth of beech decreased by 20-30\% in the past 30 years which contrasts with the rather stable diameter growth of beech in the moister stands A and B (645-685 mm y ${ }^{-1}$ ). The growth decline cannot be related to tree age, because the age of the F. sylvatica trees was very similar in the three stands. Rather, our results suggest that recent climatic warming is driving 


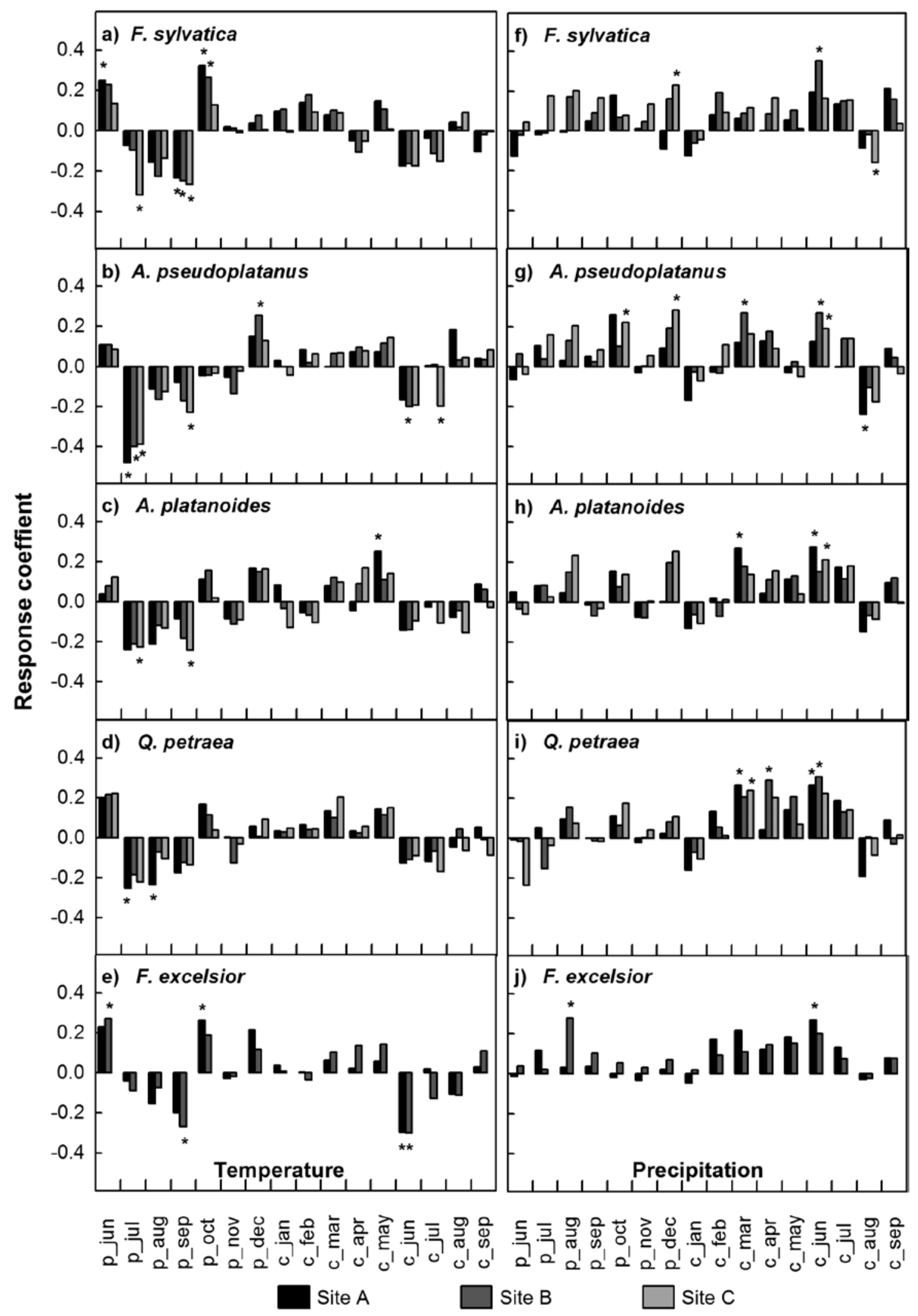

Figure 2.5. Response coefficients of the bootstrapped response function of annual diameter growth to monthly means of temperature or precipitation totals for previous (p) year's June to December and current (c) year's January to September. Asterisks mark significant response coefficients. The $95 \%$-confidence intervals are not depicted for clarity of presentation. 
the species to its physiological limits at the dry end of the precipitation gradient. In fact, the annual increment of the older F. sylvatica trees was not smaller in the driest stand $\mathrm{C}$ than in the moister stands $\mathrm{A}$ and B before 1980 (Fig. 2.8), when warming was much weaker than more recently (IPCC 2013). Moreover, the summers became increasingly drier in the period 1954-2010 in the study region. The climate sensitivity analysis of growth supports the assumption that both high summer temperatures and low summer precipitation are the main climate factors limiting diameter growth in $F$. sylvatica.

On the basis of our SEA results, the growth of F. sylvatica was not more sensitive to extreme drought than that of the other species. A possible explanation is that F. sylvatica can withstand single drought events quite successfully. However, this species is negatively affected when more than one dry summer is occurring successively. This interpretation is supported by the finding that beech showed the most negative pointer years and also strongest growth depressions when two or more dry summers happened in sequence.

The vitality of $F$. sylvatica could also be affected by high summer temperatures and this might be an alternative explanation for the marked growth decline of the species in stand C since the 1980s. This is

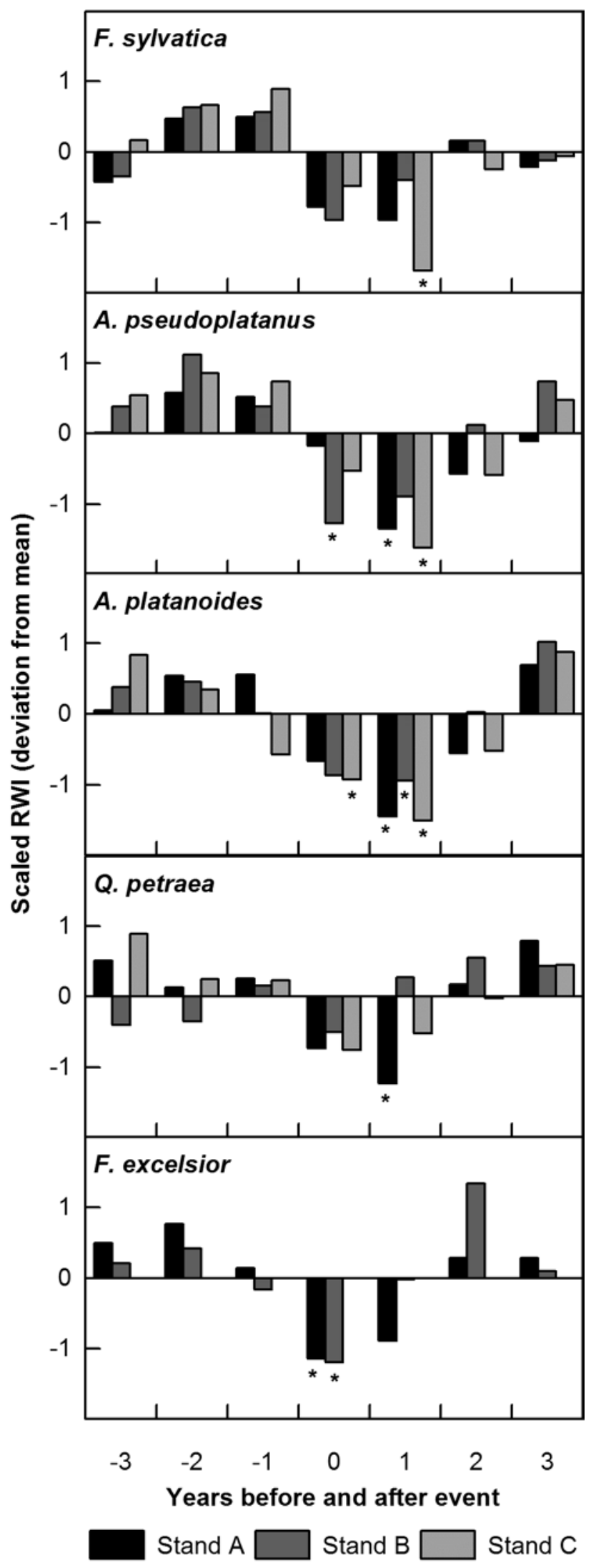

Figure 2.6. Superposed epoch analysis of ring-width index and site specific most severe summer droughts (SPEI <-1) in the period 1954-2010 for all five species. Asterisks mark significant changes $(\mathrm{p}<0.05)$ 


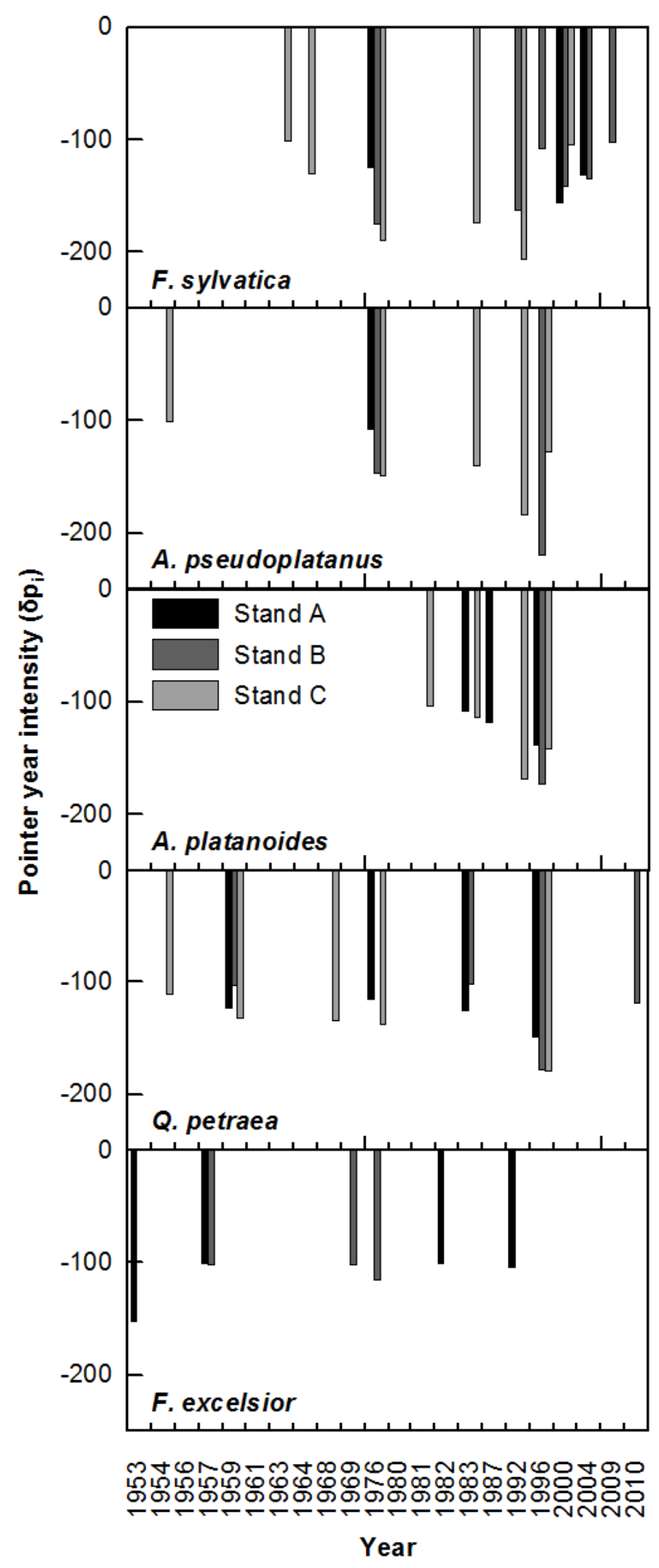

Figure 2.7. Negative pointer years and their intensity since 1951 in the five species in the stands A to C. suggested by the striking coincidence between the negative trend in radial growth and the synchronous increase in temperatures of the vegetation period (April - September) during the last three decades. A close relation between rising annual temperatures and growth reduction was also observed by Jump et al. (2006) in Spanish F. sylvatica forests. Rising summer temperatures could negatively impact on the vitality of F. sylvatica through several mechanisms. Higher respirative carbon losses and thus reduced carbohydrate availability for growth (Barbeta et al. 2013), and a higher atmospheric demand for water vapor, which may deteriorate the water status in leaf and stem tissues (e.g. Köcher et al. 2012), are among the most likely mechanisms. In many cases, elevated summer temperatures and reduced precipitation likely interact in their negative impact on the growth of $F$. sylvatica.

What precipitation or temperature threshold exists for vital growth may not only depend on the amount of summer precipitation and summer temperature means or maxima, but on the water storage capacity of the soil as well. While our gradient study suggests that a summer precipitation 
(June - August) of $\sim 190 \mathrm{~mm}$, or an annual precipitation of $600-640 \mathrm{~mm}$, may represent a critical minimum water supply threshold for mature beech stands on loamy to clayey soils, beech stands on sandy soils in north-eastern Germany showed a growth reduction at $540 \mathrm{~mm} \mathrm{y}^{-1}$, but not at 595 or $663 \mathrm{~mm} \mathrm{y}^{-1}$ (Scharnweber et al. 2011). Higher soil water storage may have shifted the critical precipitation amount to somewhat lower values in this study.

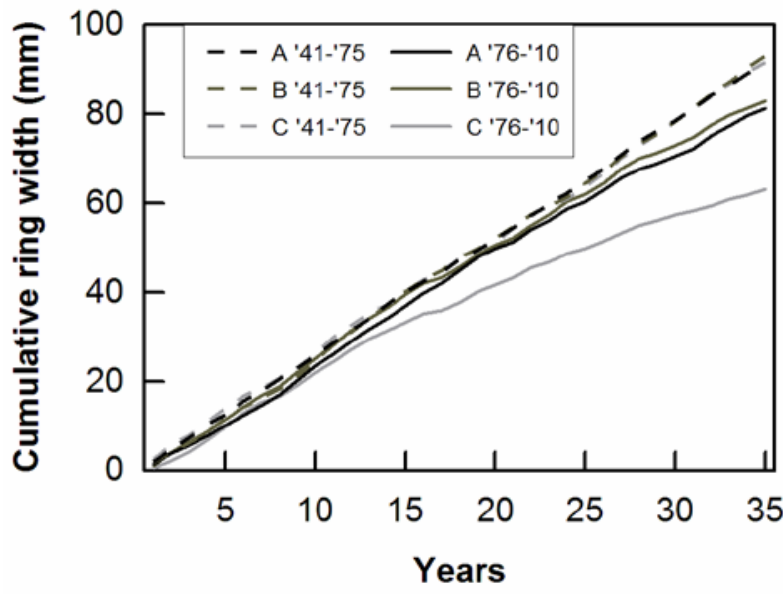

Figure 2.8. Cumulative diameter increment of F. sylvatica trees in two 35-y-periods (1941-1975, 1976-2010) in the stands A to C. Precipitation gradient studies on different soils are needed for a more precise determination of the hydrological limits of F. sylvatica.

\section{Species differences in drought sensitivity}

We use five criteria for assessing the drought sensitivity of tree growth, (i) the mean sensitivity of a tree-ring chronology, (ii) the impact of summer drought on growth as measured with the SEA, (iii) the frequency and intensity of negative pointer years in the last 60 years that were likely caused by drought, (iv) if mean tree-ring width decreased along the transect, and (v) if increment has decreased with an increase in summer drought in the past 20-30 years. Mean climate sensitivity was significantly smaller in the two ring-porous species (F. excelsior and Q. petraea) than in the three diffuse-porous species (F. sylvatica and the two Acer species), at least in the drier stands. This is also valid for the extent of growth reduction in severe drought years. With the exception of the older trees at stand A, Q. petraea showed only a slight, but non-significant, growth reduction in dry summers; F. excelsior recovered quickly after a drought. The growth reduction was strongest in the two Acer species,

$F$. sylvatica and $Q$. petraea are the species with highest frequency of pointer years, but the temporal distribution and the underlying causes are different. Negative pointer years in Q. petraea were often not related to summer drought, but to a dry spring and/or exceptionally cold winter. Correspondingly, spring precipitation has been found to strongly influence the vessel size of earlywood in Q. petraea (Fonti and Garcia-Gonzalez 2008). Different climatic drivers are likely the reason for the fact that the frequency of negative pointer years did not 
increase in Q. petraea in recent time, as it did in F. sylvatica, were the most negative pointer years are found in the period 1990-2010. Pointer year frequency was lower in A. pseudoplatanus and A. platanoides, but pointer years were usually related to summer drought and had, as in F. sylvatica, a higher intensity than in the ring-porous species Q. petraea and F. excelsior.

We judge the negative growth trend observed since about 1980 as the most relevant of the above-defined five criteria for assessing drought sensitivity. Only F. sylvatica revealed such a trend. This suggests, in conjunction with the high number of pointer years, that beech is the most drought-sensitive species in our sample. The role of increasing summer temperatures and their interaction with growing water shortage still awaits detailed study. That pointer year frequency in beech did not increase in the last decades in the dry stand C, which contrasts with the moister stands A and B, may be related to the lower standard deviation of ring width in the last 20-30 years, when the radial growth of beech declined in this stand.

While the Acer species showed a stronger growth depression upon severe summer drought, they were able to recover growth more quickly and showed neither an increase in pointer year frequency, nor a recent reduction in growth rate. This suggests that both maple species are better adapted to drought and/or elevated temperatures than F. sylvatica. Q. petraea and F. excelsior appeared as the least sensitive species. It has to be kept in mind that our species comparison is not fully balanced due to the fact that F. excelsior is not present in the driest stand (C) and thus can only partly be compared with the other species. In addition, the Q. petraea trees were older than their competitors in the stands A and B.

Despite these shortcomings, a synoptic view on our results suggests that $F$. sylvatica is the species with highest sensitivity to drought, followed by the Acer species, and finally F. excelsior and Q. petraea. This ranking matches ecophysiological results obtained in other Central European mixed forests. Köcher et al. (2009) compared five broad-leaved tree species in terms of leaf water status, sap flow and hydraulic properties under drought and also found F. sylvatica to be the most sensitive species followed by A.pseudoplatanus, while F. excelsior was least sensitive. A similar species ranking was obtained by Scherrer et al. (2011) who investigated the drought sensitivity of six broad-leaved species using canopy surface temperature and sap flow patterns as indicators.

Several ecophysiological, dendrochronological and modeling studies in beech-oak mixed forests revealed a markedly higher drought tolerance of $Q$. petraea than of $F$. sylvatica (Backes and Leuschner 2000; Leuschner et al. 2001; Scherrer et al. 2011; Mette et al. 2013). A remarkable insensitivity to drought events, even on relatively shallow Regosols, is also 
shown by dendrochronological analysis for Q. petraea forests in Luxembourg (Härdtle et al. 2013). Bonn (1998) could show that the competitive superiority of F. sylvatica over Q. petraea in mixed stands declines with a reduction in precipitation in central and eastern Germany. A corresponding result was obtained by Scharnweber et al. (2011) in F. sylvatica/Q. robur mixed stands along a precipitation gradient in NE Germany, indicating that beech loses advantage over oak on Pleistocene sandy soils with medium to low water storage capacity at a precipitation of $\sim 540 \mathrm{~mm} \mathrm{y}^{-1}$. Our results further suggest that the competitive strength of Q. petraea and that of other species, in comparison to F. sylvatica may well increase with climate warming in the future.

\section{Tree functional traits possibly related to climate sensitivity}

Species differences in sensitivity to drought and high temperatures, as they appear for adult trees from this study, might result from various morphological and physiological characteristics. The occurrence of growth depressions in dry summers (or in the years following dry summers) might result from the same processes that are thought to cause drought-induced tree death: reduced carbon gain due to stomatal or biochemical limitation of photosynthesis; shedding of leaves and fine roots; hydraulic failure which deteriorates leaf and stem water status; and drought-induced increase in the vulnerability to pathogen and herbivore attack (Bréda et al. 2006; Allen et al. 2010). An alternative explanation of droughtinduced growth reduction was proposed by Müller-Hauboldt et al. (2013) who showed that F. sylvatica forests on sandy soil in northern Germany with $<600 \mathrm{~mm} \mathrm{y}^{-1}$ of precipitation did not differ in their total (above- and belowground) net primary production from stands with more than $700 \mathrm{~mm} \mathrm{y}^{-1}$. They found that beech trees shifted carbon allocation under reduced precipitation to fine root growth and, in masting years, to fruit production, so that less $\mathrm{C}$ was available for stem growth. The frequency of masting events of beech has increased during the last decades in Central Europe (Hilton and Packham 2003; Schmidt 2006; Övergaard et al. 2007). Thus, in theory, the observed increase in pointer year frequency in beech since about the 1980s could in part be a consequence of increased fruit production, which could have enhanced the negative impact of increasing summer drought in the last decades. Unfortunately, information on masting is not available for our stands. Nevertheless, the large negative response coefficients for the temperature effect on growth of $F$. sylvatica for previous year's July, August and September seem to support this assumption. High temperatures in summer have repeatedly been identified as likely determinants of beech fruit production in the following year (Piovesan and Adams 2001; Drobyshev et al. 2010; Müller- 
Hauboldt et al. 2013) which could then reduce wood growth. Soil drought as well as soil temperature may also trigger increased fine root production/turnover in F. sylvatica (Leuschner et al. 2001; Meier and Leuschner 2008; Mainero and Kazda 2006; Hertel et al. 2013), resulting in lower stem increment.

Further research has to show whether the beech growth decline since about 1980 in the driest stand is caused by a direct effect of increased temperature/summer drought on stem growth, or an indirect effect via increased fruit production/increased fine root turnover. It is likely that several factors are interacting.

We see three areas where more research effort is urgently needed. (1) Elevated summer temperatures could represent a direct stressor for trees adapted to oceanic, relatively cool environments, as was observed in Acer saccharum (Filewod 2011). (2) More research is needed about the importance of air humidity as a soil water-independent growth controlling factor (e.g. Köcher et al. 2012) because the atmospheric saturation deficit will increase with higher summer temperatures. (3) It is not yet clear which life stage of the trees (juvenile or adult) is most sensitive to drought. Pot experiments with tree saplings did not reveal a particularly high drought vulnerability of F. sylvatica in a sample of 20 Central European broad-leaved and coniferous tree species that were exposed to defined soil drought (Sommer and Leuschner, unpubl. results). If masting would be an important factor causing growth reductions in drought-affected F. sylvatica trees, younger trees should be less affected, as significant fruit production does not start before an age of $\sim 60$ years in F. sylvatica and is increasing with age (Genet et al. 2010).

Whether young and old F. sylvatica trees are differing in their response to climate and drought is an important question when predicting the future competitive strength of this species. If increasing temperatures and summer drought affect young trees in a similar way as adults, it is likely that F. sylvatica will lose its dominant position in mixed forests with less than $\sim 600 \mathrm{~mm} \mathrm{yr}^{-1}$ precipitation in the future. 


\section{Acknowledgements}

This research was funded by the DFG (Deutsche Forschungsgemeinschaft) within the project GRK 1086 "The role of biodiversity for biogeochemical cycles and biotic interactions in temperate deciduous forests" which is gratefully acknowledged. We thank the DBU (Deutsche Bundesstiftung Umwelt) and the administration of the Biosphere Reserve Karstlandschaft-Südharz for allowing to conduct tree coring in their stands. We thank the DWD (Deutscher Wetterdienst, Offenbach) for supplying climate data. We also like to thank Stefan Meyer (Göttingen) for his support in the early phase of the project. Finally, we thank two anonymous reviewers for their helpful comments and suggestions on an earlier version of the paper. 


\section{References}

Allen CD, Macalady AK, Chenchouni H, Bachelet D, McDowell N, Vennetier M Kitzberger T, Rigling A, Breshears DD, Hogg EH, Gonzalez P,Fensham R, Zhang Z, Castro J, Demidova N, Lim JH, Allard G, Running SW, Semerci A, Cobb N. 2010. A global overview of drought and heat-induced tree mortality reveals emerging climate change risks for forests. Forest Ecology and Management 259: 660-684.

Ammer C, Albrecht L, Borchert H, Brosinger F, Dittmar C, Elling W, Ewald J, Felbermeier B, von Gilsa H, Huss J, Kenk G, Kölling C, Kohnle U, Meyer P, Mosandl R, Moosmayer HU, Palmer S, Reif A, Rehfuess KE, Stimm B. 2004. Future suitability of beech (Fagus sylvatica L.) in Central Europe: critical remarks concerning a paper of Rennenberg et al. (2004). Allgemeine Forst- und Jagdzeitung 176: 60-67.

Backes K, Leuschner C. 2000. Leaf water relations of competitive Fagus sylvatica and Quercus petraea trees during 4 years differing in soil drought. Canadian Journal of Forest Research 30: 335-346.

Baillie MG, Pilcher, JR. 1973. A simple cross-dating program for tree-ring research. TreeRing Bulletin 33: 7-14.

Barbeta A, Ogaya R, Penuelas J. 2013. Dampening effects of long-term experimental drought on growth and mortality rates of a Holm oak forest. Global Change Biology 19: 31333144.

Bonn S. 1998. Dendroökologische Untersuchung der Konkurrenzdynamik in Buchen/EichenMischbestanden und zu erwartende Modifikationen durch Klimaänderungen. Forstwissenschaftliche Beitrage Tharandt/Contributions to Forest Sciences No. 3. Dresden, Germany.

Bräuning A.1999. Zur Dendroklimatologie Hochtibets während des letzten Jahrtausends. Dissertationes Botanicae 312: 1-164.

Bréda N, Huc R, Granier A, Dreyer E. 2006. Temperate forest trees and stands under severe drought: a review of ecophysiological responses, adaptation processes and long-term consequences. Annals of Forest Science 63: 625-644.

Bugmann H. 1997. Sensitivity of forests in the European Alps to future climatic change. Climate Research 8: 35-44.

Bunn AG. 2008. A dendrochronology program library in R (dplR). Dendrochronologia 26: 115-124.

Cavin L, Mountford PE, Peterken GF, Jump AS. 2013. Extreme drought alters competitive dominance within and between tree species in a mixed forest stand. Functional Ecology 27: 1424-1435. 
Della-Marta PM, Luterbacher J, Weissenfluh H, Xoplaki E, Brunet M, Wanner H. 2007. Summer heat waves over western Europe 1880-2003, their relationship to large-scale forcings and predictability. Climate Dynamics 29: 251-275.

Dixon PM 2001 Bootstrap resampling. El-Shaarawi AH, Piegorsch WW, editors. The Encyclopedia of Environmetrics. Wiley, New York p212-220.

Drobyshev I, Övergaard R, Saygin I, Niklasson M, Hickler T, Karlsson M, Sykes MT. 2010. Masting behaviour and dendrochronology of European beech (Fagus sylvatica L.) in southern Sweden. Forest Ecology and Management 259: 2160-2171.

Eckstein D, Bauch J. 1969. Beitrag zur Rationalisierung eines dendrochronologischen Verfahrens und zur Analyse seiner Aussagesicherheit. Forstwissenschaftlisches Centralblatt 88: 230-250.

Ellenberg H, Leuschner C. 2010. Vegetation Mitteleuropas mit den Alpen in ökologischer, dynamischer und historischer Sicht. 6th ed. Stuttgart: Ulmer.

Filewod B. 2011. Effects of an early season heat wave on ecophysiological parameters related to productivity in Sugar maple (Acer saccharum Marsh.). MSc Thesis, Faculty of Forestry, University of Toronto, Canada.

Fonti P, García-González I. 2008. Earlywood vessel size of oak as a potential proxy for spring precipitation in mesic sites. Journal of Biogeography 35: 2249-2257.

Friedrichs DA, Trouet V, Büntgen, Frank DC, Esper J, Neuwirth B, Löffler J. 2009. Speciesspecific climate sensitivity of tree growth in Central-West Germany. Trees 23: 729739.

Fritts HC. 2001. Tree Rings and Climate. Caldwell, N.J: Blackburn Press.

Genet H, Breda N, Dufrene E. 2010. Age-related variation in carbon allocation at tree and stand scales in beech (Fagus sylvatica L.) and sessile oak (Quercus petraea (Matt.) Liebl.) using a chronosequence approach. Tree Physiology 30: 177-192.

Guiot J. 1991. The bootstrapped response function. Tree-Ring Bulletin 51: 39-41.

Härdtle W, Niemeyer T, Assmann T, Aulinger A, Fichtner A. Lang A, Leuschner C, Neuwirth B, Pfister L, Quante M, Ries C, Shuldt A, Oheimb G. 2013. Climatic responses of tree-ring width and $\delta 13 \mathrm{C}$ signatures of sessile oak (Quercus petraea Liebl.) on soils with contrasting water supply. Plant Ecology 214: 1147-1156.

Hertel D, Strecker T, Müller-Haubold H, Leuschner C. 2013. Fine root biomass and dynamics in beech forests across a precipitation gradient - is optimal resource partitioning theory applicable to water-limited mature trees? Journal of Ecology 101: 1183-1200.

Hilton GM, Packham JR. 2003. Variation in the masting of common beech (Fagus sylvatica L.) in northern Europe over two centuries (1800-2001). Forestry 76: 319-328. 
Jacob D. 2009. Regionalisierte Szenarien des Klimawandels. Raumforschung und Raumordnung 67: 89-96.

Jump AS, Hunt JM, Penuelas J. 2006. Rapid climate change-related growth decline at the southern range edge of Fagus sylvatica. Global Change Biology 12: 2163-2174.

Köcher P, Gebauer T, Horna V, Leuschner C. 2009. Leaf water status and stem xylem flux in relation to soil drought in five temperate broad-leaved tree species with contrasting water use strategies. Annals of Forest Science 66: 101.

Köcher P, Horna V, Leuschner C. 2012. Environmental control of daily stem growth patterns in five temperate broad-leaved tree species. Tree Physiology 32: 1021-1032.

Köcher P, Horna V, Leuschner C. 2013. Stem water storage in five coexisting temperate broad-leaved tree species: significance, temporal dynamics and dependence on tree functional traits. Tree Physiology 33: 817-832.

Lakatos F, Molnár M. 2009. Mass mortality of beech (Fagus sylvatica L.) in South-West Hungary. Acta Silvatica and Lignaria Hungarica 5: 75-82.

Leuschner C, Backes K, Hertel D, Schipka F, Schmitt U, Terborg O, Runge M. 2001. Drought responses at leaf, stem and fine root levels of competitive Fagus sylvatica L. and Quercus petraea (Matt.) Liebl. trees in dry and wet years. Forest Ecology and Management 149: 33-46.

Leuschner C. 2009. Die Trockenheitsempfindlichkeit der Rotbuche vor dem Hintergrund des prognostizierten Klimawandels. In: Jahrbuch der Akademie der Wissenschaften zu Göttingen. Berlin: Walter de Gruyter, 281-296.

Lindner M, Maroschek M, Netherer S Kremer A, Barbati A, Garcia-Gonzalo J, Seidl R, Delzon S, Corona P, Kolström M, Lexer M, Marchetti M. 2010. Climate change impacts, adaptive capacity, and vulnerability of European forest ecosystems. Forest Ecology and Management 259: 698-709.

Lloret F, Keeling EG, Sala A. 2011. Components of tree resilience: effects of successive lowgrowth episodes in old ponderosa pine forests. Oikos 120: 1909-1920.

Mainiero R, Kazda M. 2006. Depth-related fine root dynamics of Fagus sylvatica during exceptional drought. Forest Ecology and Management 237: 135-142.

Meier IC, Leuschner C. 2008. Leaf size and leaf area index in Fagus sylvatica Forests: Competing effects of precipitation, temperature, and nitrogen availability. Ecosystems 11: 655-669.

Mette T, Dolos K, Meinardus C, Bräuning A, Reineking B, Blaschke M, Pretzsch H, Beierkuhnlein C, Gohlke A, Wellstein C. 2013. Climate turning point for beech and oak under climate change in Central Europe. Ecosphere 4: 1-19. 
Müller-Haubold H, Hertel D, Seidel D, Knutzen F, Leuschner C. 2013. Climate responses of aboveground productivity and allocation in Fagus sylvatica: A transect study in mature forests. Ecosystems 16: 1498-1516.

Overgaard R, Gemmel P, Karlsson M. 2007. Effects of weather conditions on mast year frequency in beech (Fagus sylvatica L.) in Sweden. Forestry 80: 555-565.

Piovesan G, Adams JM. 2001. Masting behaviour in beech: linking reproduction and climatic variation.Canadian Journal of Botany 79: 1039-1047.

Piovesan G, Biondi F, Di Fillipo A, Maugeri M. 2008. Drought-driven growth reduction in old beech (Fagus sylvatica L.) forests of the central Apennines, Italy. Global Change Biology 14: 1265-1281.

R Development Core Team. 2008. R: A language and environment for statistical computing. R Foundation for Statistical Computing, Vienna, Austria. ISBN 3-900051-07-0, URL http://www.R-project.org.

Rennenberg H, Seiler W, Matyssek R, Gessler A, Kreuzwieser J. 2004. European beech (Fagus sylvatica L.) - a forest tree without future in the south of Central Europe? Allgemeine Forst- und Jagdzeitung 175: 210-224.

Schär C, Vidale PL, Lüthi D, Frei C, Häberli C, Liniger MA, Appenzeller C. 2004. The role of increasing temperature variability in European summer heatwaves. Nature 427: 332-336.

Scharnweber T, Manthey M, Criegee C, Bauwe A, Schröder A, Wilmking M. 2011. Drought matters - Declining precipitation influences growth of Fagus sylvatica L. and Quercus robur L. in north-eastern Germany. Forest Ecology and Management 262: 947-961.

Scherrer D, Bader KFB, Körner C. 2011. Drought-sensitivity ranking of deciduous tree species based on thermal imaging of forest canopies. Agriculture and Forest Meteorology 151: 1632-1640.

Schmidt W. 2006. Temporal variation in beech masting (Fagus sylvatica L.) in a limestone beech forest (1981- 2004). Allgemeine Forst- und Jagdzeitung 177: 9-19.

Schönwiese CD, Janoschitz R. 2008. Klima-Trendatlas Deutschland 1901-2000. Berichte des Instituts für Atmosphäre und Umwelt der Universität Frankfurt/Main, Germany.

Schweingruber FH, Eckstein D, Serre-Bachet F, Bräker OU. 1990. Identification, presentation and interpretation of event years and pointer years in dendrochronology. Dendrochronologia 8: 9-38.

Seidling W, Ziche D, Beck W. 2012. Climate responses and interrelations of stem increment and crown transparency in Norway spruce, Scots pine, and common beech. Forest Ecology and Management 284: 196-204. 
Spekat A, Enke W, Kreienkamp F. 2007. Neuentwicklung von regional hoch aufgelösten Wetterlagen für Deutschland und Bereitstellung regionaler Klimaszenarios auf der Basis von globalen Klimasimulationen mit dem Regionalisierungsmodell WETTREG auf der Basis von globalen Klimasimulationen mit ECHAM5/MPI-OM T63L31 2010 bis 2100 für die SRES Szenarios B1, A1B und A2. - Forschungsprojekt im Auftrag des Umweltbundesamtes FuE-Vorhaben Förderkennzeichen 20441 138. Dessau, Germany.

IPCC, 2013: Summary for Policymakers. In: Climate Change 2013: The Physical Science Basis. Contribution of Working Group I to the Fifth Assessment Report of the Intergovernmental Panel on Climate Change. Stocker TF, Qin D, Plattner GK, Tignor M, Allen SK, Boschung J, Nauels A, Xia Y, Bex V, Midgley PM, editors.

Cambridge University Press, Cambridge, United Kingdom and New York, NY, USA.

Thornthwaite CW. 1948. An approach toward a rational classification of climate. Geographical Review 38: 55-94.

VFS (2005) Waldökologische Naturräume Deutschlands. Mitteilungen des Vereins für Forstliche Standortskunde und Forstpflanzenzüchtung 43.

Vincente-Serrano SM, Begueria S, Lopez-Moreno JI. 2009. A multiscalar drought index sensitive to global warming: The standardized precipitation evapotranspiration index. Journal of Climate 23: 1696-1718.

Wigley TML, Briffa KR, Jones PD. 1984. On the average value of correlated time series, with applications in dendroclimatology and hydrometeorology. Journal of Climate and Applied Meteorology 23: 201-213.

Zang C, Biondi F. 2013. Dendroclimatic calibration in R: The bootRes package for response and correlation function analysis. Dendrochronologia 31: 68-74.

Zang C. 2012. Wachstumsreaktion von Baumarten in temperierten Wäldern auf Sommertrockenheit: Erkenntnisse aus einem Jahrringnetzwerk. Mitteilungen der Deutschen Dendrologischen Gesellschaft 93: 29-46. 


\section{Chapter 3}

60-yr record of stem xylem anatomy and related hydraulic modification under reduced precipitation in ring- and diffuse-porous temperate broad-leaved tree species

Jorma Zimmermann • Bernhard Schuldt • Markus Hauck • Christoph Leuschner 



\section{Summary}

The hydraulic architecture of the root-to-shoot flow path may play a crucial role for the productivity and drought tolerance of trees, but we do not fully understand how the hydraulic system is adapting to a warmer and drier climate. Based on existing dendroecological evidence of recent growth decline in Central European F. sylvatica populations, we combined dendrochronological time-series analysis with the calculation of stem hydraulic properties derived from xylem anatomical analysis. We aimed to reconstruct the development of the hydraulic system over six decades for five co-occurring broad-leaf tree species (genera Acer, Fagus, Fraxinus and Quercus) and to identify climatic determinants of xylem anatomy. Hydraulically-weighted vessel diameter (Dh) increased in radial direction with tree size by 8$19 \%$ since 1951 in four of the five species despite a recorded increase in climatic aridity. Fagus sylvatica, in contrast, increased vessel frequency (Vf) in the last 60 years by 11-19\% but kept Dh constant. As a result, potential hydraulic conductivity (Kp) increased in all species since 1951 by 11-93\%. An even larger increase was found for Kann, the conductivity generated by annual ring growth; in F. sylvatica, however, Kann decreased due the observed growth decline. While climate response analysis revealed that Dh tends to decrease with increasing climatic aridity, our results show a marked age (or tree size) effect on Dh, Vf, Kp and Kann, which overlays the climate effects. A comparison of stands across a precipitation gradient showed that Vf increased under lowered precipitation in F. sylvatica, while Kp remained relatively constant in all species. Our results revealed considerable adaptability in the hydraulic system especially of F. sylvatica (smaller Dh but increased Vf under dry conditions) but also evidence the drought sensitivity of this species in accordance with earlier dendroecological and physiological studies. We conclude that the long-term reconstruction of hydraulic properties can add substantially to the understanding of tree growth responses to climate change.

Keywords: Climate warming, dendrochronology, drought adaptation, Fagus sylvatica, hydraulic conductivity, vessel diameter, wood anatomy. 


\section{Introduction}

Drought is a key factor limiting tree vitality and growth in many regions of the temperate zone (Allen et al. 2010). Climate models for Central Europe predict a decrease in mean summer precipitation and an increasing frequency and severity of extreme drought periods (Schär et al. 2004, Jacob 2009, IPCC 2013). A crucial role for tree productivity and vitality is played by the water transport system from roots to leaves, which has to be efficient under conditions of ample water supply in order to enable high photosynthetic rates, while being resistant to hydraulic failure in periods of drought (Hacke \& Sperry 2001). With the warming and drying of climate, hydraulic functioning and its adaptability should gain increasing importance for tree vitality and growth in the future (Fonti et al. 2010). Adapting the hydraulic architecture to changing hydrologic regimes may be a bigger challenge for broadleaved trees than for conifers due to the generally higher cavitation vulnerability of the xylem of the former (Maherali, Pockman \& Jackson 2004). In correspondence, hydraulic safety margins were found to be generally larger in gymnosperms than in angiosperm trees (Choat et al. 2012). Owing to the obvious threats imposed on forestry by a future drier climate, a better understanding of adaptation processes in the hydraulic system of broad-leaved trees to environmental change is urgently needed.

Dendrochronological studies and forest inventory data indicate that Fagus sylvatica L. (European beech), the dominant tree species of Central Europe's natural vegetation at elevations below $\sim 800 \mathrm{~m}$ a.s.l., is facing recent growth decline and even increased tree mortality in various regions of its distribution range, which were attributed to a climate warming-related increase in drought intensity (Jump, Hunt \& Penuelas 2006; Poivesan et al. 2008; Charru et al. 2010; Scharnweber et al. 2011; Mette et al. 2013; Zimmermann et al. 2015). In the decades to come, this could lead in certain regions to a shift in tree species composition in mixed forests where beech is the dominant species today (Lindner et al. 2010; Czúcz, Gálhidy \& Mátyás 2011; Hlasny et al. 2011; Cavin et al. 2013).

While various physiological and dendrochronological studies have indeed characterized F. sylvatica as a drought-sensitive species which shows sensitive reductions in water consumption and radial stem growth during dry episodes (e.g. Rennenberg et al. 2004; Köcher et al. 2009; Leuschner 2009), it is also regarded as a highly adaptive tree able to cope with stress events (Bolte, Czajkowski \& Kompa 2007; Rose et al. 2009; Kramer et al. 2010; Schuldt et al. 2015). As a consequence, controversial scenarios of the future of Fagus sylvatica forests in central Europe under a warmer and drier climate have been discussed (e.g. Rennenberg et al. 2004; Ammer et al. 2005). While considerable attention has been paid to 
drought effects on radial stem growth, pre-senescent leaf shedding, drought and heat stress effects on photosynthesis, and drought-induced fine root mortality in F. sylvatica (Dreyer 1997; Leuschner et al. 2001; Bréda et al. 2006; Piovesan et al. 2008; Scharnweber et al. 2011; Zimmermann et al. 2015), not much is known about the adaptability of the stem hydraulic system of this species. A pioneering study in this direction is that of Wortemann et al. (2011) who found a relatively high adaptability of the embolism resistance of branches of F. sylvatica provenances to site-specific environmental conditions, but significant differences between sites across Europe. A recent study in mature F. sylvatica trees along a precipitation gradient in northern Germany confirms the high acclimation potential of branch wood with respect to embolism resistance (Schuldt et al. 2015). Both studies evidence the high plasticity of the hydraulic system of beech to changing environmental conditions. According to Eilmann et al. (2014) and Hajek, Schuldt \& Leuschner (unpubl. results), wood anatomical properties seem to be mostly under genetic control in this species, while embolism resistance may largely depend on the environment (Wortemann et al. 2011, Schuldt et al. 2015).

The present study builds on the dendrochronological study of Zimmermann et al. (2015) in a five-species mixed forest which demonstrated that F. sylvatica suffers strongest growth reductions in drought episodes among the five co-occurring tree species. Beech also revealed increasing growth sensitivity to elevated temperatures since the 1980s in the driest stand. Studies in Picea abies suggest that drought-induced growth decline might eventually lead to increased tree mortality (Bigler et al. 2006). This raises the question as to whether F. sylvatica in the center of its distribution range will experience increased mortality rates in future with continued increase of climatic aridity in the course of global warming. A crucial factor in this scenario is how the hydraulic system of beech can adapt to these climatic changes and whether growth decline and associated reduction in hydraulic capacity will limit the water transport to the crown. This perspective has been outlined by Manion (2006) in his forest decline concept.

We adopt two complementary approaches of studying hydraulic adaptation to water shortage in mature trees of F. sylvatica and compare it with four other co-occurring broad-leaved tree species. First, we analyzed 60-yr-long time series of anatomical and derived hydraulic properties of the stem xylem from a period with significant warming and increasing climatic aridity. Second, xylem anatomy and associated hydraulic traits derived from the anatomical measurements were examined in stands along a precipitation gradient spanning roughly 100 $\mathrm{mm} \mathrm{yr}-1$; the dry end of the gradient approaches the assumed drought limit of F. sylvatica in Central Europe (Ellenberg \& Leuschner 2010). We investigated three mixed forests in which 
F. sylvatica co-occurs with maple (Acer pseudoplatanus L., Acer platanoides L.), oak (Quercus petraea (Matt.) Liebl.), and ash (Fraxinus excelsior L.). With respect to the water consumption patterns under soil desiccation and increased evaporative demand (Köcher et al. 2009) and the observed drought-sensitivity of stem growth (Zimmermann et al. 2015), ringporous oak and ash were assessed as being less drought-sensitive than beech.

Building on the dendrochronological companion study, we aimed (i) to examine modifications in the stem hydraulic architecture of the five species in response to permanent reduction in precipitation (precipitation gradient study), (ii) to search for long-term trends in the hydraulic properties of annual rings in response to declining summer precipitation (time series analysis), and (iii) to compare ring- and diffuse-porous species with respect to their adaptability to decreasing rainfall. We tested the hypotheses that (1) the studied species adjust their xylem anatomy to a drier and warmer climate by reducing vessel diameter for lowering the risk of embolism formation, (2) drought-sensitive F. sylvatica shows the most pronounced vessel diameter reduction of the five species, and (3), in dry summers, potential hydraulic conductivity is reduced due to both smaller vessel diameters and narrower annual rings. 


\section{Material and methods}

Study area and sampled stands

The study took place in central Germany in three mixed forests along a precipitation gradient from 685 to $590 \mathrm{~mm} \mathrm{yr}^{-1}$ in the transition zone between a sub-oceanic climate in the west and a more sub-continental climate in the east (see chapter 2: Fig. 2.1, Table 2.1). The three forests are located at 250 - 450 m elevation between the villages of Keula and Wettelrode in the lee of the Harz Mountains (south-western Saxony-Anhalt and northern Thuringia). In the study region with a west-east extension of only $50 \mathrm{~km}$, European beech comes close to its drought limit (Ellenberg and Leuschner 2010) and the three stands are situated in the assumed transition zone between beech-dominated forests in a moister sub-oceanic climate (stand A) to mixed forests with higher abundance of Quercus, Acer, Tilia, Fraxinus and Carpinus species under a more summer-dry sub-continental climate (stands B and C, Table 2.1). The three selected diffuse-porous species F. sylvatica, A. pseudoplatanus and A.platanoides and the two ring-porous species Q. petraea and F. excelsior vary largely in wood anatomical traits and assumed drought response strategies (Köcher et al. 2009); they are of moderate to high relevance for forestry.

The study region is characterized by small-scale variation in geological substrates (VFS 2005); two of the stands are located on Triassic limestone, one on pellite rock (Table 2.1). All studied trees had an age of $\sim 100 \mathrm{yr}$ and a DBH mostly in the range of 40-55 cm; exceptions were older and thicker oak trees in stand A. Nevertheless, DBH tended to decrease toward the driest stand $\mathrm{C}$ in all five species. All stands grew on north-facing slopes with higher inclination in stand $\mathrm{C}\left(20-30^{\circ}\right)$ than in $\mathrm{A}$ and $\mathrm{B}\left(5-10^{\circ}\right)$. The former stand stocked on a mosaic of limestone and igneous rocks with variable soil depth; beech typically grew on the shallower and oak on the deeper soils.

\section{Climate data}

Weather stations recording precipitation were available in the neighborhood of all three stands (Table 2.1), while only one station in the study region recorded temperature (station Artern, 164 m a.s.l., Deutscher Wetterdienst, Offenbach, Germany; data available since 1954).

Gaps in the precipitation record from the stations near stands B and C were interpolated using data from other stations. Drought intensity was quantified with the standardized precipitationevapotranspiration index (SPEI) (Vincente-Serrano et al. 2010) using the SPEI package v 1.6 for the R software v. 2.15 (R Development Core Team 2012). For calculating monthly values of potential evapotranspiration (PET) with the Thornthwaite (1948) formula, data of mean 
monthly precipitation and temperature and a coefficient derived from latitude for estimating day length were used. SPEI was calculated using indices with a log-logistic probability distribution and parameter fitting based on unbiased probability-weighted moments. A resolution of only one month was selected for covering short drought episodes, which might affect drought-sensitive tree species on shallow soils. To detect long-term change in summer drought intensity in the period 1951-2010, linear regressions between the averaged SPEI index of the months June to August and time (year) were performed.

\section{Wood core sampling and preparation}

For the wood anatomical measurements, each five wood cores of the five target tree species were collected from different trees in the three stands in the period July-October 2011. The trees selected for sampling belonged to the upper canopy layer, were comparable in DBH and height among the species and belonged to the largest and tallest trees of the stands. Two cores of A. platanoides from stand A showed micro-cracks during the preparation process and could not be analyzed, resulting in only three cores for this species in stand A. Trees of F. excelsior were absent from stand $\mathrm{C}$ and thus were only sampled in stands A and B. In total, 68 wood cores were analyzed. Samples were collected at breast height $(1.3 \mathrm{~m})$ with an increment borer of $5.15 \mathrm{~mm}$ inner diameter (Haglöf, Langsele, Sweden) from that position where the least influence of wood tension or compression was expected. The cores were mounted on wood strips, cut and leveled with a core microtome which can handle samples of up to $40 \mathrm{~cm}$ length (Gärtner and Nievergelt 2010). The wood was dyed with safranin and the vessels filled with chalk-powder and subsequently analyzed for wood anatomical properties at $100 \times$ magnification using a Stereo V20 Microscope equipped with an automatic table using the software AxioVision S64 Rel 4.9 (Zeiss, Oberkochen, Germany). About 500 images per core were taken from different sections, each focused individually, and subsequently combined to one large image for analysis; exemplary images are shown in Fig. 3.1. The contrast of the images was enhanced using the graphics editing software Photoshop CS6 (Adobe Systems, San Jose, USA). Finally, the images were split into the annual rings for analyzing conduit dimensions and density individually for every annual ring of the 60 years from 1951 to 2010, yielding 4080 analyzed rings in total. 

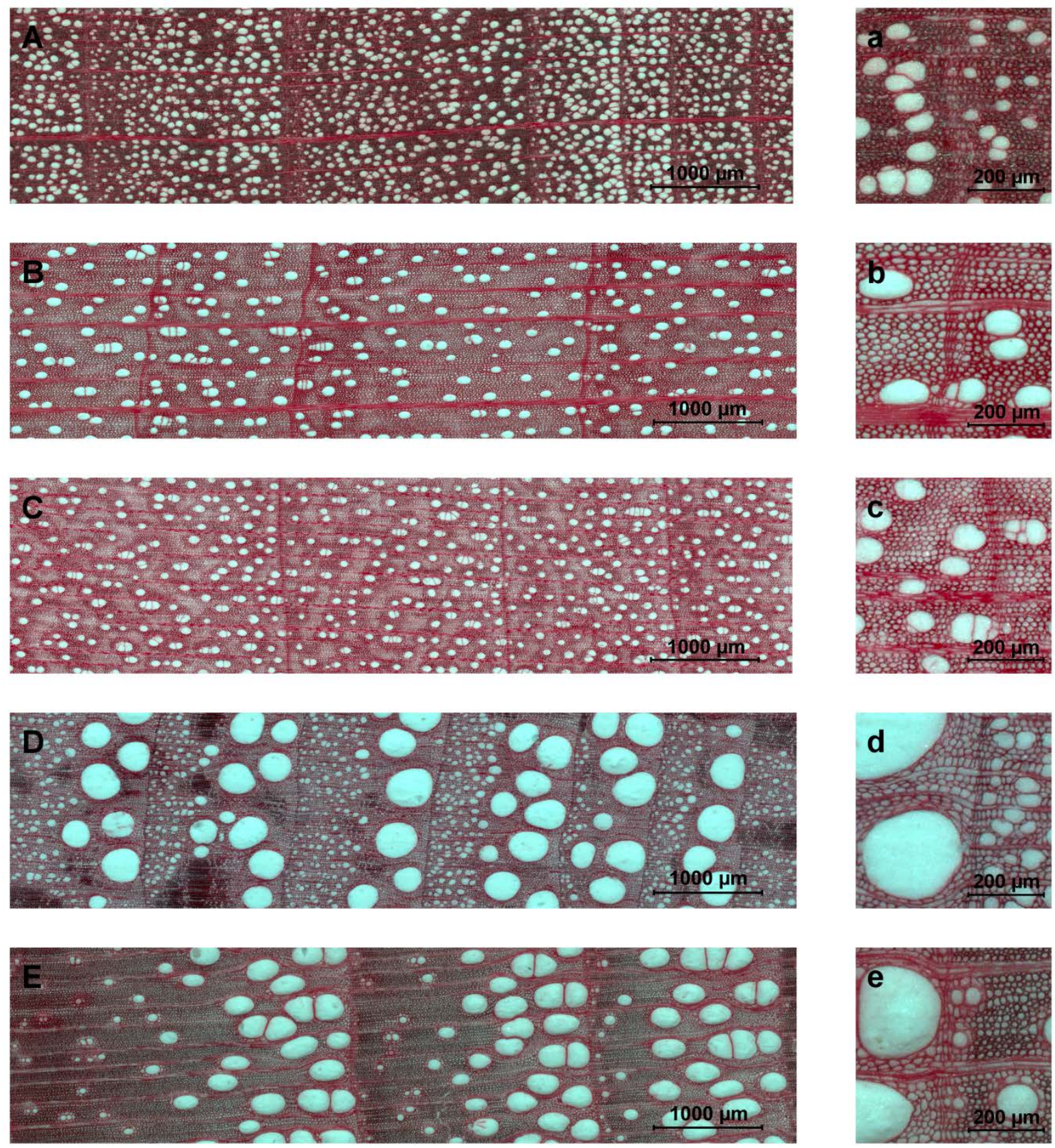

Figure 3.1. Cross-sections of stem xylem of the three diffuse-porous (A-C) and two ring-porous (D-E) tree species at 100x magnification. A - Fagus sylvatica, B - Acer pseudoplatanus, C - Acer platanoides, D Quercus petraea, E - Fraxinus excelsior.

\section{Analysis of vessel properties}

Vessel properties were analyzed with WinCELL software v. 2011a (Régent Instruments, Quebec, Canada). We analyzed only vessels but not tracheids and considered only vessels with a lumen area $\geq 500 \mu \mathrm{m}^{2}$; per tree and species, 4,928 to 61,550 vessels were measured, yielding 1,336,832 analyzed vessels in total. Smaller vessels were ignored because they may be confused with tracheids in the software analysis and they are of minor importance for hydraulic conductance. The measured parameters included the area of the tree-ring segment 


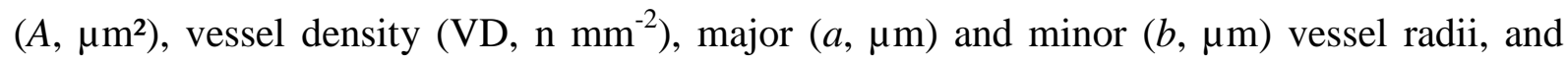
vessel lumen area. The latter was used to estimate relative vessel lumen area, i.e. the lumen to sapwood area ratio $\left(A_{\text {lumen }}, \%\right)$. Idealized vessel diameters $(D, \mu \mathrm{m})$ were calculated according to White (1991) as $D=\left(\left(32 \times(a \times b)^{3}\right) /\left(a^{2}+b^{2}\right)\right)^{1 / 4}$ and used to calculate hydraulicallyweighted vessel diameter $D_{\mathrm{h}}(\mu \mathrm{m})$ after Sperry et al. (1994) as $D_{\mathrm{h}}=\mathrm{S} D^{5} / \mathrm{S} D^{4}$.

The theoretical hydraulic conductivity $\left(K_{\mathrm{h}}, \mathrm{kg} \mathrm{m} \mathrm{MPa}^{-1} \mathrm{~s}^{-1}\right)$ of a tree-ring segment was calculated by adding up the conductance of all vessels as obtained from Hagen-Poiseuille's equation as $K_{\mathrm{h}}^{\text {theo }}=\left(\left(\mathrm{p} \times \mathrm{S} D^{4}\right) / 128 h\right) \times r$, where $\eta$ is the viscosity $\left(1.00210^{-9} \mathrm{MPa} \mathrm{s}\right)$ and $\rho$ the density of water $\left(998.2 \mathrm{~kg} \mathrm{~m}^{-3}\right)$, both at $20^{\circ} \mathrm{C}$. When divided by the corresponding area of the tree-ring segment $\left(A, \mathrm{~m}^{2}\right)$, the potential sapwood area-specific hydraulic conductivity $\left(K_{\mathrm{p}}\right.$, $\mathrm{kg} \mathrm{m}^{-1} \mathrm{MPa}^{-1} \mathrm{~s}^{-1}$ ) for the considered xylem segment was obtained. By multiplying $K_{\mathrm{p}}$ with the basal area increment (BAI) of the corresponding year, the potential hydraulic conductivity was extrapolated to the whole tree-ring. This parameter is termed annual conductivity ( $K_{\mathrm{ann}}$, $\mathrm{kg} \mathrm{m} \mathrm{MPa}{ }^{-1} \mathrm{~s}^{-1}$ ) and estimates the potential conductivity that was produced by the tree in the course of secondary xylem formation in the respective year. It should be noted that the actual hydraulic conductivity in the stem consists of $K_{\text {ann }}$ (most recent annual ring) and the conductivity of an unknown number of still active conduits in older tree rings.

\section{Climate response analysis}

Prior to climate response analysis, the $D_{\mathrm{h}}$ series where detrended with a linear fit, as the increase in $D_{\mathrm{h}}$ over time was mostly linear. Series of $F$. sylvatica were not detrended, as detrending these series using a linear fit or a spline did not produce reasonable results. Instead, data were standardized by fitting a horizontal line derived from the time series' mean. All standardized data sets had a mean of 1 and thus were comparable in the climate response analysis. Only hydraulically-weighted vessel diameter $\left(D_{\mathrm{h}}\right)$ was used in climate response analysis, as it is the only anatomical parameter that is not or only marginally influenced by ring width in both diffuse- and ring-porous trees. For quantifying inter-annual differences in water availability, we used the standardized precipitation-evapotranspiration index (SPEI). The relations between $D_{\mathrm{h}}$ and SPEI for different months of the year of, or prior to, ring formation were analyzed with bootstrapped response functions (Guiot 1991) using the R package bootRes v 1.2.3 (Zang and Biondi, 2013). This package uses bootstrap re-sampling for calculating response coefficients for 1000 samples drawn randomly with replacement from the calibration set. Significance was tested using the 95\% percentile range method (Dixon 
2001). Analyses were done for the months from previous year's June to current year's September and covered the period 1954-2010.

\section{Statistical analyses}

Arithmetic means \pm SD are presented throughout the paper. All data sets were tested for normal distribution with the Shapiro-Wilk test. Homogeneity of variances was tested with Levene's test. The General Linear Hypotheses (glht) procedure with Tukey's post-hoc test (contained in the "multcomp" package) was used to test for significant differences between means (Herberich et al. 2010). Statistical analyses were calculated with R 2.15 software. The significance level was set to $\alpha \leq 0.05$ throughout the study.

\section{Results}

\section{Climate trends}

Annual mean temperature increased in the study region by $\sim 1.6 \mathrm{~K}$ (or $0.29 \mathrm{~K}$ per decade) from 1954 to $2010\left(\mathrm{R}^{2}=0.29, \mathrm{p}<0.001\right)$. This increase was observed in all seasons except for autumn and it was particularly strong in the months February - May and July/August (Table S3.1). There was no significant change in annual precipitation but summer drought intensity as quantified by the SPEI increased from 1954 to 2010 (see Chapter 2: Fig 2.2).

\section{Temporal change in hydraulic architecture}

The sampled trees were comparable in age and size; a notable exception are the older and larger Q. petraea trees in stand A (Table 3.1). We found a marked age effect on mean hydraulically-weighted vessel diameter $\left(D_{\mathrm{h}}\right)$ in all species except $F$. sylvatica (Fig. 3.2). The increase in $D_{\mathrm{h}}$ during the 60-yr observation period (1951 - 2010) was visible in each tree individual (though not always significant) with the exception of the two oldest $Q$. petraea individuals in stand $\mathrm{A}$ and each one A. pseudoplatanus (stand B) and A.platanoides tree (stand C). In F. sylvatica, $D_{\mathrm{h}}$ did not increase with age (or tree size); it even decreased in stand A. In the diffuse-porous species, an age trend was also detected for vessel density (VD) but the direction of change was different among the species with an increase since 1951 in F. sylvatica in all stands but a decrease in A.pseudoplatanus (stand A and C) and A. platanoides (stand C; Fig. 3.3). 
Table 3.1. Structural data of the sampled trees from the five tree species within the three stands. Given are tree age (at breast height; yr) and height $(\mathrm{m})$ as well as diameter at breast height (DBH, $\mathrm{cm})$. Values are means $\pm \mathrm{SD}$. Different small letters indicate significant differences between means.

\begin{tabular}{ccccc}
\hline & Stand & Age* & DBH $(\mathbf{c m})$ & Height $(\mathbf{m})$ \\
\hline \multirow{3}{*}{ F. sylvatica } & A & $89 \pm 7^{\mathrm{a}}$ & $51.6 \pm 8.7^{\mathrm{ac}}$ & $31.8 \pm 1.2^{\mathrm{ab}}$ \\
& B & $101 \pm 20^{\mathrm{a}}$ & $52.8 \pm 5.1^{\mathrm{ac}}$ & $31.9 \pm 2.5^{\mathrm{ab}}$ \\
& C & $98 \pm 12^{\mathrm{a}}$ & $45.6 \pm 5.3^{\mathrm{ab}}$ & $29.6 \pm 0.9^{\mathrm{bc}}$ \\
\hline \multirow{3}{*}{ A. pseudoplatanus } & A & $100 \pm 8^{\mathrm{a}}$ & $50.1 \pm 5.0^{\mathrm{ab}}$ & $31.8 \pm 1.2^{\mathrm{ab}}$ \\
& B & $105 \pm 25^{\mathrm{a}}$ & $53.4 \pm 5.4^{\mathrm{bc}}$ & $29.8 \pm 1.9^{\mathrm{bc}}$ \\
& C & $87 \pm 19^{\mathrm{a}}$ & $46.2 \pm 10.0^{\mathrm{ab}}$ & $27.7 \pm 2.8^{\mathrm{c}}$ \\
\hline \multirow{2}{*}{ A. platanoides } & A & $90 \pm 8^{\mathrm{a}}$ & $41.7 \pm 1.6^{\mathrm{ab}}$ & $30.2 \pm 2.9^{\mathrm{bc}}$ \\
& B & $101 \pm 18^{\mathrm{a}}$ & $51.6 \pm 8.5^{\mathrm{ac}}$ & $27.9 \pm 1.8^{\mathrm{cd}}$ \\
& C & $109 \pm 8^{\mathrm{a}}$ & $38.6 \pm 6.9^{\mathrm{a}}$ & $27.9 \pm 2.3^{\mathrm{cd}}$ \\
\hline \multirow{2}{*}{ F. excelsior } & A & $158 \pm 11^{\mathrm{b}}$ & $64.9 \pm 5.8^{\mathrm{c}}$ & $30.9 \pm 1.8^{\mathrm{bc}}$ \\
& B & $109 \pm 15^{\mathrm{a}}$ & $55.7 \pm 5.8^{\mathrm{bc}}$ & $29.6 \pm 1.4^{\mathrm{bc}}$ \\
& C & $110 \pm 4^{\mathrm{a}}$ & $48 \pm 5.7^{\mathrm{ab}}$ & $29.4 \pm 1.7^{\mathrm{acd}}$ \\
\hline & A & $96 \pm 10^{\mathrm{a}}$ & $51.4 \pm 6.8^{\mathrm{ac}}$ & $32.1 \pm 1.5^{\mathrm{bd}}$ \\
& B & $97 \pm 16^{\mathrm{a}}$ & $52.2 \pm 3.6^{\mathrm{ac}}$ & $33.6 \pm 1.2^{\mathrm{b}}$ \\
\hline
\end{tabular}

In Q. petraea and F. excelsior, trends in VD were very inconsistent, presumably because early- and latewood was not analyzed separately. As a result of the changes in $D_{\mathrm{h}}$ and VD with age, $K_{\mathrm{p}}$ increased over the 60 years in all species and all stands except for $F$. sylvatica in the wettest stand A (Fig. 3.4a-e). In beech, the $K_{\mathrm{p}}$ increase in stands B and C was caused by increasing VD since 1951, which compensated the decreasing or stable $D_{\mathrm{h}}$.

When $K_{\mathrm{p}}$ is extrapolated to the cumulative hydraulic conductivity generated by the formation of new xylem in that year $\left(K_{\mathrm{ann}}\right)$, the influence of and age and thus growth on conductivity becomes even more obvious (Fig. 3.4f-j). In all species with the exception of beech, $K_{\mathrm{ann}}$ showed a non-linear increase in the observation period that generally exceeded that of $K_{\mathrm{p}}$ due to the non-linear increase in basal area. In F. sylvatica, on the other hand, $K_{\mathrm{ann}}$ slightly increased only in stand B but showed an optimum curve in stands A and C with a conductivity reduction since the 1990s, thereby reflecting the recent reduction in basal area increment (BAI) in these stands.

\section{Species and stand differences in hydraulic architecture}

The comparison of the hydraulic architecture between species and stands was confined to the last ten years (2001-2010) to reflect acclimation to the recent climate and to account for agerelated changes in xylem structure. 

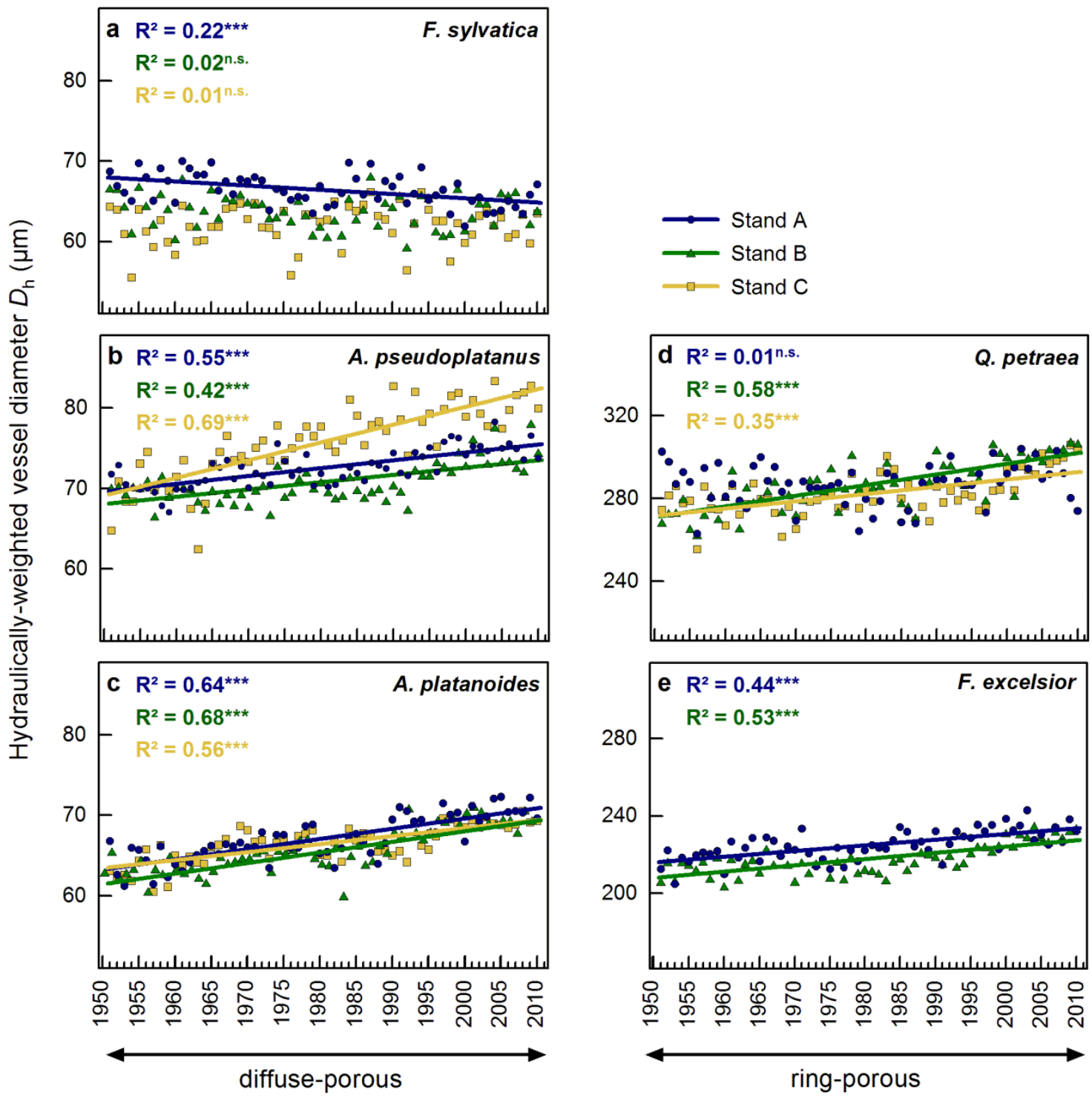

Figure 3.2. Radial variation in hydraulically-weighted mean vessel diameter $\left(D_{\mathrm{h}}, \mu \mathrm{m}\right)$ for the five species in the period 1951-2010 (means of each five trees per species and site are given). Level of significance is given as ${ }^{\text {n.s. }}$ : not significant, *: $\mathrm{p}<0.05, * *: \mathrm{p}<0.01, * * *: \mathrm{p}<0.001$.

While relative vessel lumen area ( $A_{\text {lumen, }}$ Fig. 3.5a) and VD (Fig. 3.5b) were significantly smaller in the Acer species than in F. sylvatica, no significant differences were found for mean vessel diameter $(D)$ and $D_{\mathrm{h}}$ (Fig. 3.5c-d). Among the diffuse-porous tree species, highest $K_{\mathrm{p}}$ values were observed in beech (difference to the other species not significant; Fig. 3.5e), even though both Acer species tended to possess larger vessels in their stem xylem, illustrating the importance of variation in VD and $A_{\text {lumen }}$ for hydraulic conductivity in diffuseporous species. When comparing diffuse- and ring-porous species, $K_{\mathrm{p}}$ differed by an order of magnitude due to the roughly four times larger mean $D_{\mathrm{h}}$ of $Q$. petraea and F. excelsior as compared to the diffuse-porous species. The $D_{\mathrm{h}}$ difference was mainly caused by the few very large early-wood vessels of the ring-porous species ( $D_{\mathrm{h}}$ means: $218-287 \mu \mathrm{m}$ in the ring- 

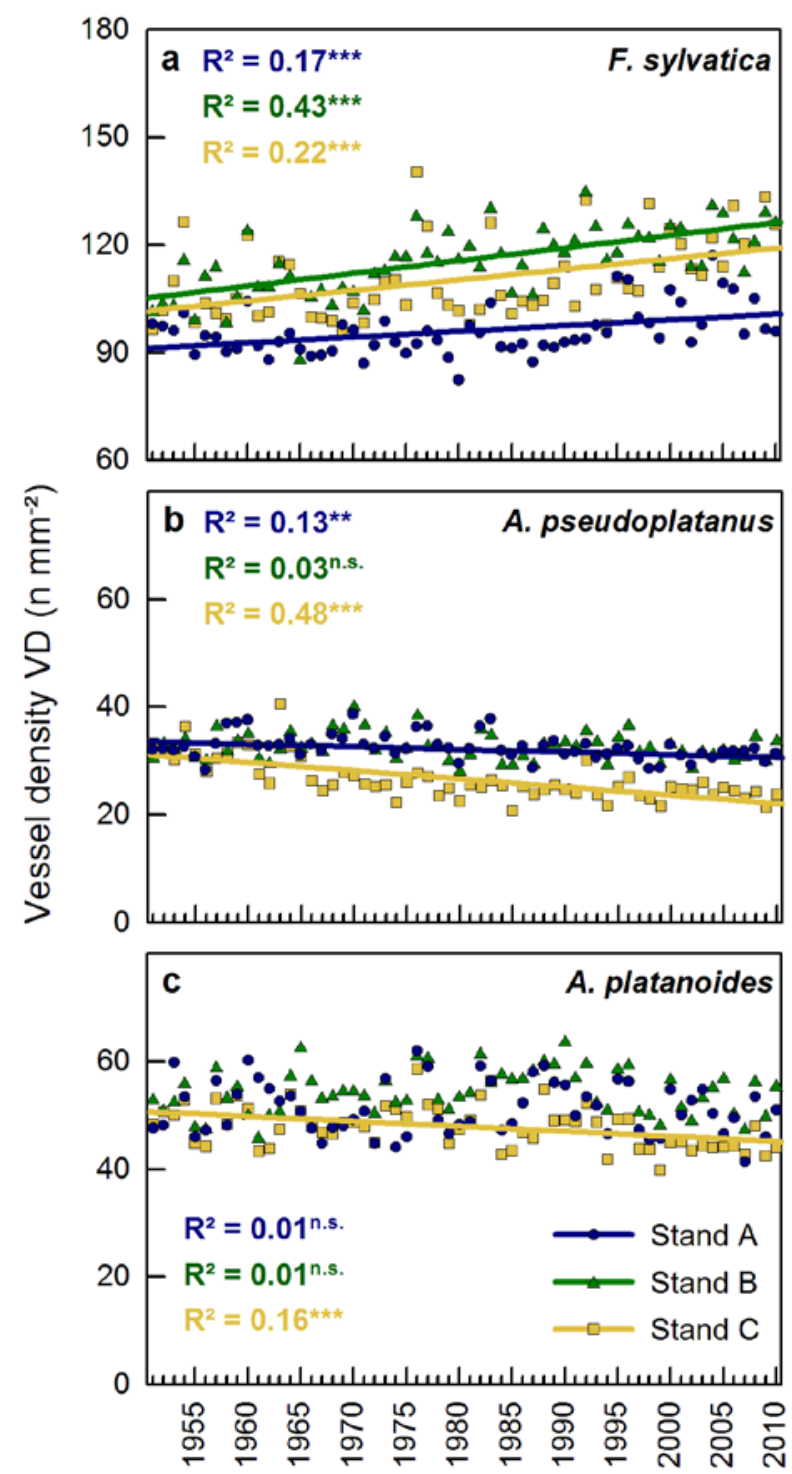

Figure 3.3. Radial variation in vessel density (VD) for the three diffuse-porous species in the period 1951-2010 (means of each five trees per species and site are given). Level of significance is given as ${ }^{\text {n.s. }}$ : not significant, $*$ : $\mathrm{p}<0.05, * *$ : $\mathrm{p}<0.01, * * *: \mathrm{p}<0.001$. porous vs. $62-75 \mu \mathrm{m}$ in the diffuse-porous species), while the two groups were much more similar with respect to mean vessel diameter.

Along the precipitation gradient, only F. sylvatica showed a significant decrease in tree-ring width (TRW) and BAI from the wet to the dry end, which was mirrored in a decrease in $K_{\text {ann }}$ (Fig. 3.5f-h). A tendency for a TRW decline with decreasing precipitation was also observed for A. platanoides, but it was not significant. The other three species revealed no clear ring width trends from the moist to the dry stands. However, when all trees of a species in the three stands were pooled, a strong inter-relationship between radial growth, and vessel density and $D_{\mathrm{h}}$ appeared for the three diffuse-porous species: a TRW decline was associated with a decrease in vessel size $\left(D_{\mathrm{h}}\right)$ but an increase in vessel density (Table 3.2). The growth xylem anatomy relation was in F. sylvatica and A.pseudoplatanus tightest in the driest stand, while in A. platanoides TRW was only related to VD but not to $D_{\mathrm{h}}$. The two ring-

porous species were not considered in these correlation analyses, because we did not separately analyze early- and latewood.

Although we detected no significant differences in average vessel size between the three stands in any of the species, graphs of vessel size frequency distribution indicate some tendencies from moist to dry stands, especially in F. sylvatica (Fig. 3.6). In beech, the ratio of small vessels (size class $40-60 \mu \mathrm{m}$ ) tended to increase at the expense of larger vessels (size class $60-80 \mu \mathrm{m}$ ) from the wet to the dry end of the precipitation gradient; this trend was not significant, however. For the other species, no clear picture emerged, which in part may be due to considerable variation in xylem anatomy among the trees of a species. 

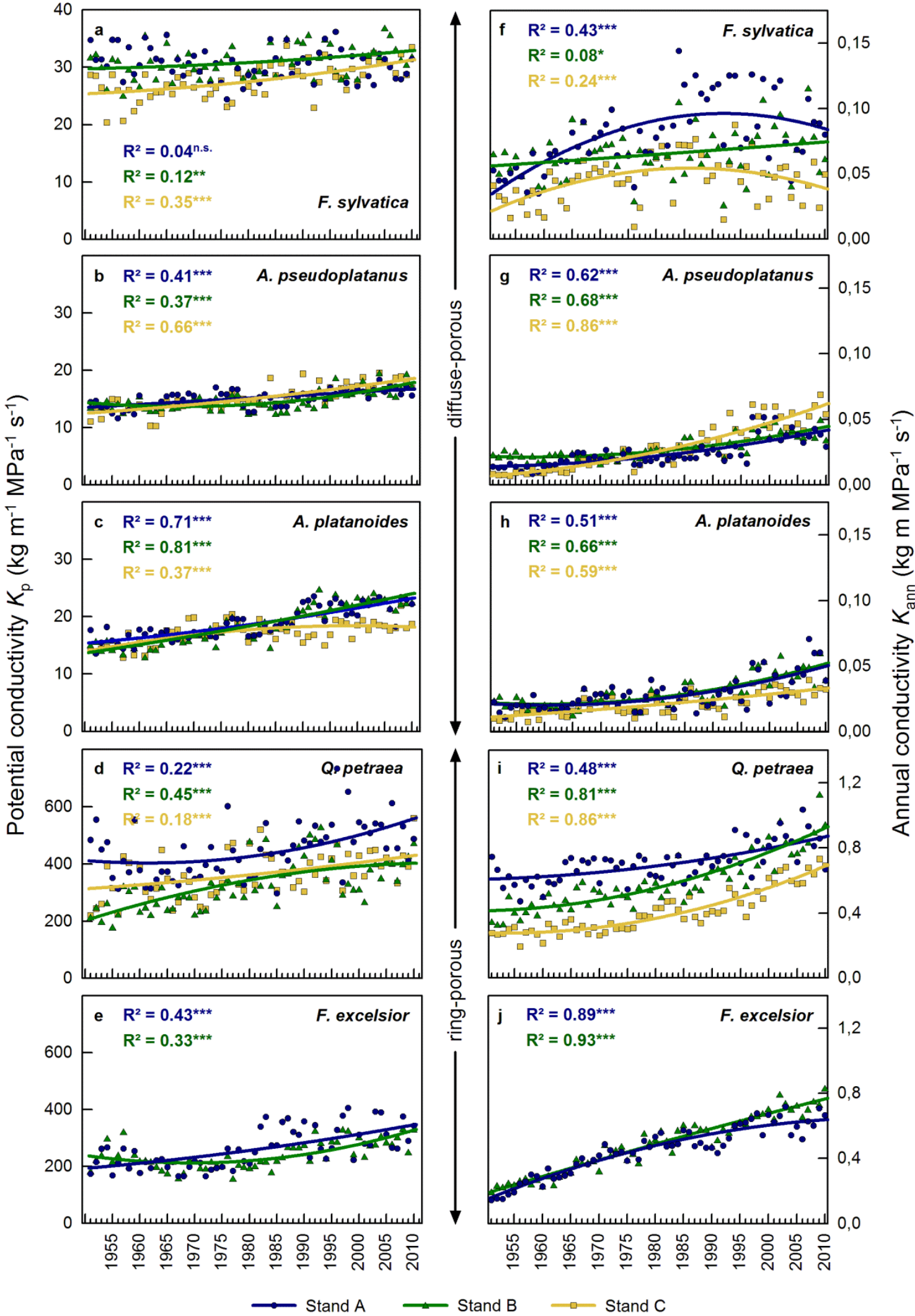

Figure 3.4. Radial variation in potential sapwood are-specific hydraulic conductivity $\left(K_{\mathrm{p}}, \mathrm{kg} \mathrm{m}^{-1} \mathrm{MPa}^{-1} \mathrm{~s}^{-1}\right.$; a-e) and annual conductivity $\left(K_{\mathrm{ann}}, \mathrm{kg} \mathrm{m} \mathrm{MPa}^{-1} \mathrm{~s}^{-1} ; \mathrm{f}-\mathrm{j}\right.$ ) of the five species in the three stands for the period 1951-2010 (means of each five trees per species and site are given). Level of significance is given as ${ }^{\text {n.s. }}$ : not significant, *: $\mathrm{p}<0.05, * *: \mathrm{p}<0.01, * * *: \mathrm{p}<0.001$. 

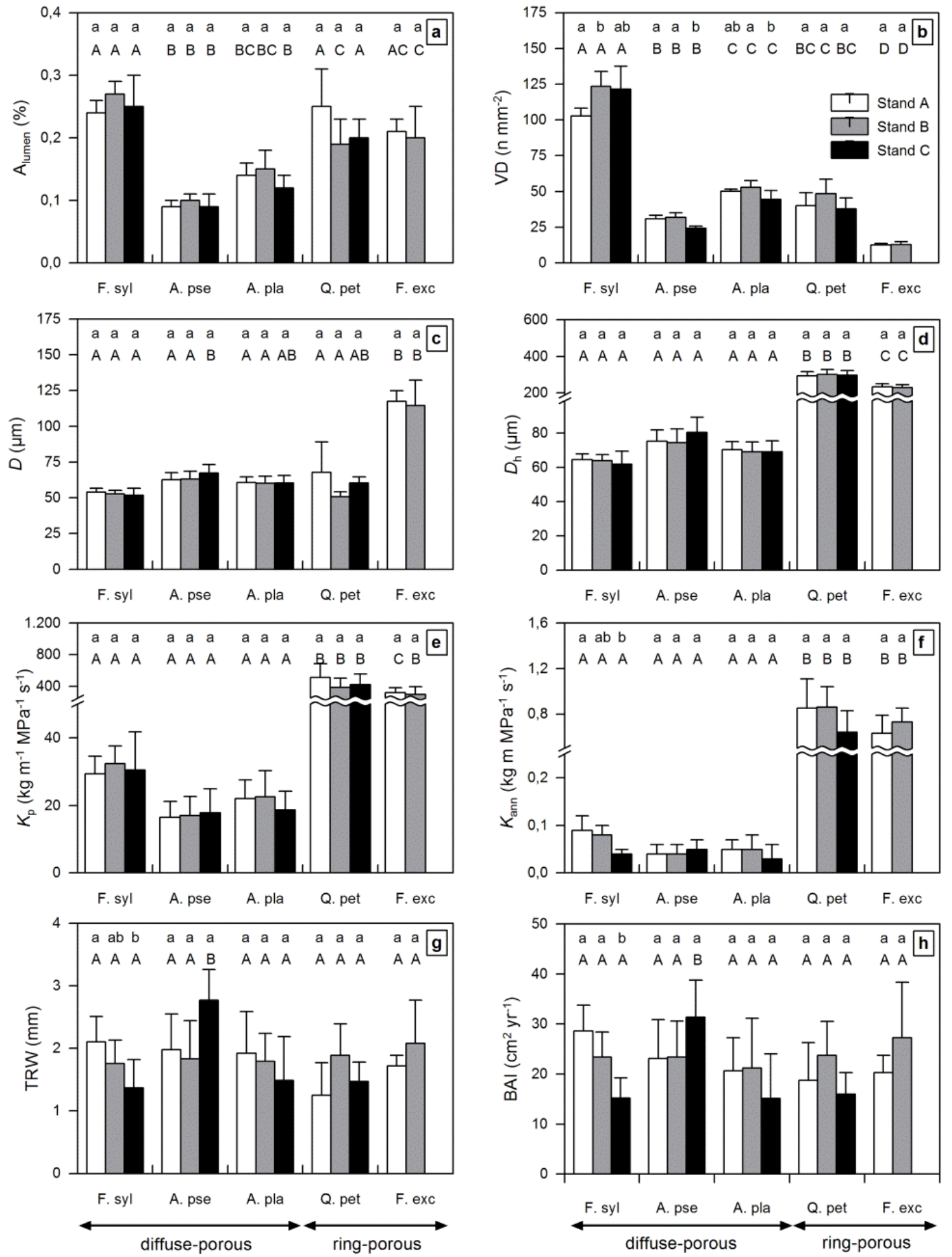

Figure 3.5. Growth-related data as well as parameters characterizing the hydraulic system of the stem xylem in the five tree species in the three stands A (white bars), B (grey bars) and C (black bars). Given are relative lumen area $\left(A_{\text {lumen, }}, \%\right)$, mean vessel diameter $(D, \mu \mathrm{m})$, hydraulically-weighted vessel diameter $\left(D_{\mathrm{h}}, \mu \mathrm{m}\right)$, vessel density (VD, n mm $\left.{ }^{-2}\right)$, potential sapwood area-specific conductivity $\left(K_{\mathrm{p}}, \mathrm{kg} \mathrm{m}^{-1} \mathrm{MPa}^{-1} \mathrm{~s}^{-1}\right)$, annual conductivity $\left(K_{\mathrm{ann}}, \mathrm{kg}\right.$ $\mathrm{m} \mathrm{MPa}^{-1} \mathrm{~s}^{-1}$ ), tree-ring width (TRW, mm) and basal area increment (BAI, $\left.\mathrm{cm}^{2} \mathrm{yr}^{-1}\right)$. Tree ring data are means per tree ring for the timespan 1951-2010. Values are means \pm SD. Different small letters indicate significant differences between means of a species at different stands, capital letters indicate significant differences between means of all species within a given stand. 
Table 3.2. Pearson correlation coefficients for within-stand correlation between hydraulically-weighted vessel diameter $\left(D_{\mathrm{h}}, \mu \mathrm{m}\right)$, vessel density $\left(\mathrm{VD}, \mathrm{n} \mathrm{mm}^{-2}\right)$ and tree-ring width (TRW, mm) for the three diffuse-porous species in stands A, B and C (means of five trees per species and stand, only three trees of A. platanoides were sampled at stand A). Letters in italics indicate non-significant coefficients ( $p>0.05)$. Ring-porous species are not listed due to the strong wood anatomical differences between early- and latewood, which were not analyzed separately, and the resulting influence on $D_{\mathrm{h}}$ and VD.

\begin{tabular}{lcccccc}
\hline $\begin{array}{l}\text { Variable } \\
\text { Stand }\end{array}$ & $\mathbf{A}$ & $\begin{array}{c}\mathbf{D}_{\mathbf{h}} \\
\mathbf{B}\end{array}$ & $\mathbf{C}$ & $\mathbf{A}$ & $\mathbf{B}$ & $\mathbf{C}$ \\
\hline Fagus sylvatica & & & & & & \\
VD & -0.54 & 0.61 & -0.75 & & & \\
TRW & 0.56 & 0.5 & 0.7 & -0.65 & -0.81 & -0.9 \\
\hline Acer pseudoplatanus & & & & & & \\
Vd & -0.58 & -0.42 & -0.85 & & & \\
TRW & -0.56 & -0.04 & 0.72 & -0.54 & -0.61 & -0.79 \\
\hline Aver platanoides & & & & & & \\
VD & -0.45 & -0.25 & -0.54 & & & \\
TRW & 0.08 & -0.18 & 0.14 & -0.79 & -0.76 & -0.65 \\
\hline
\end{tabular}
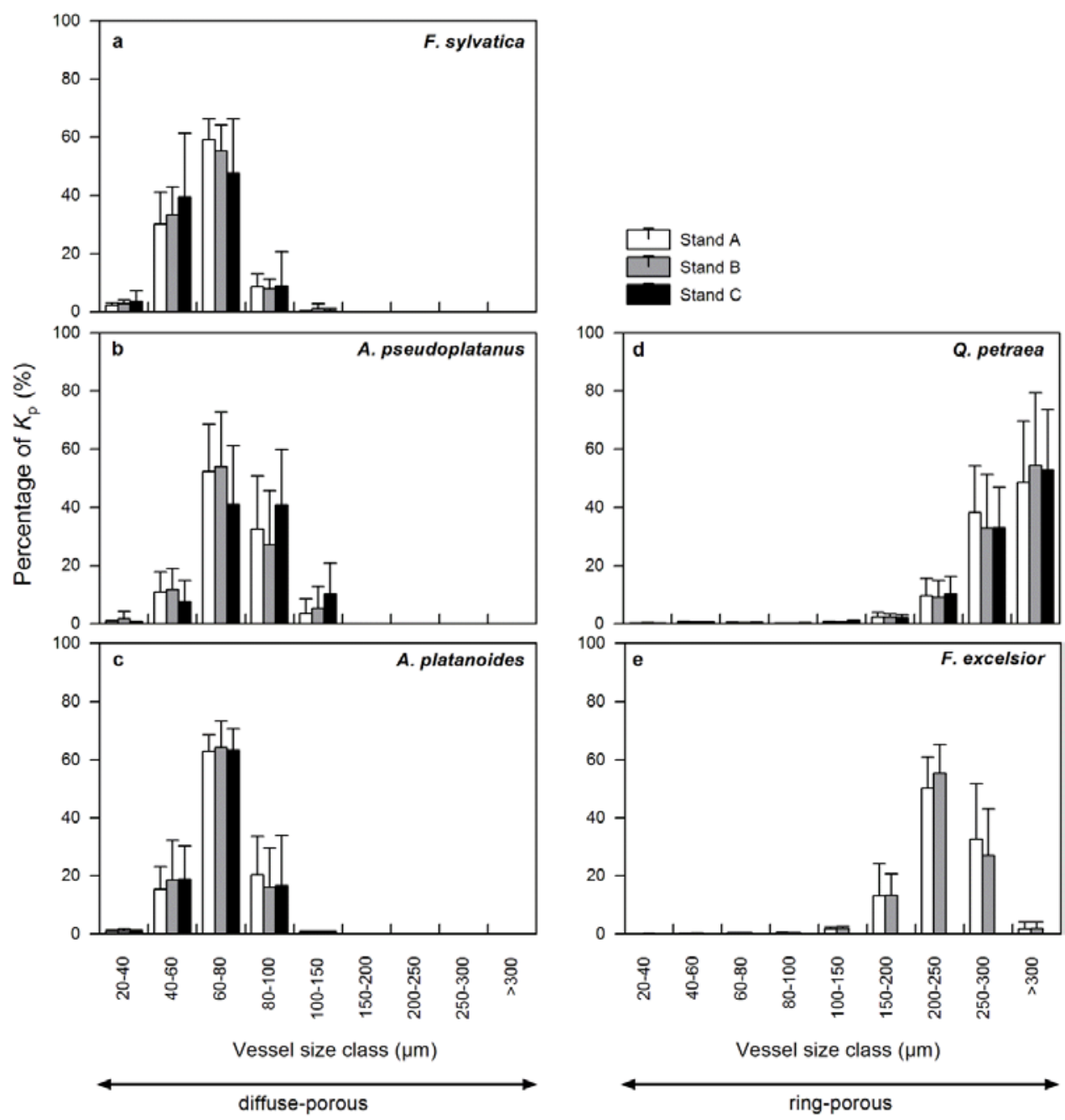

Figure 3.6. Percentage contribution of a given vessel size class to total potential conductivity for the five species and three stands. Given values are means \pm SD. 


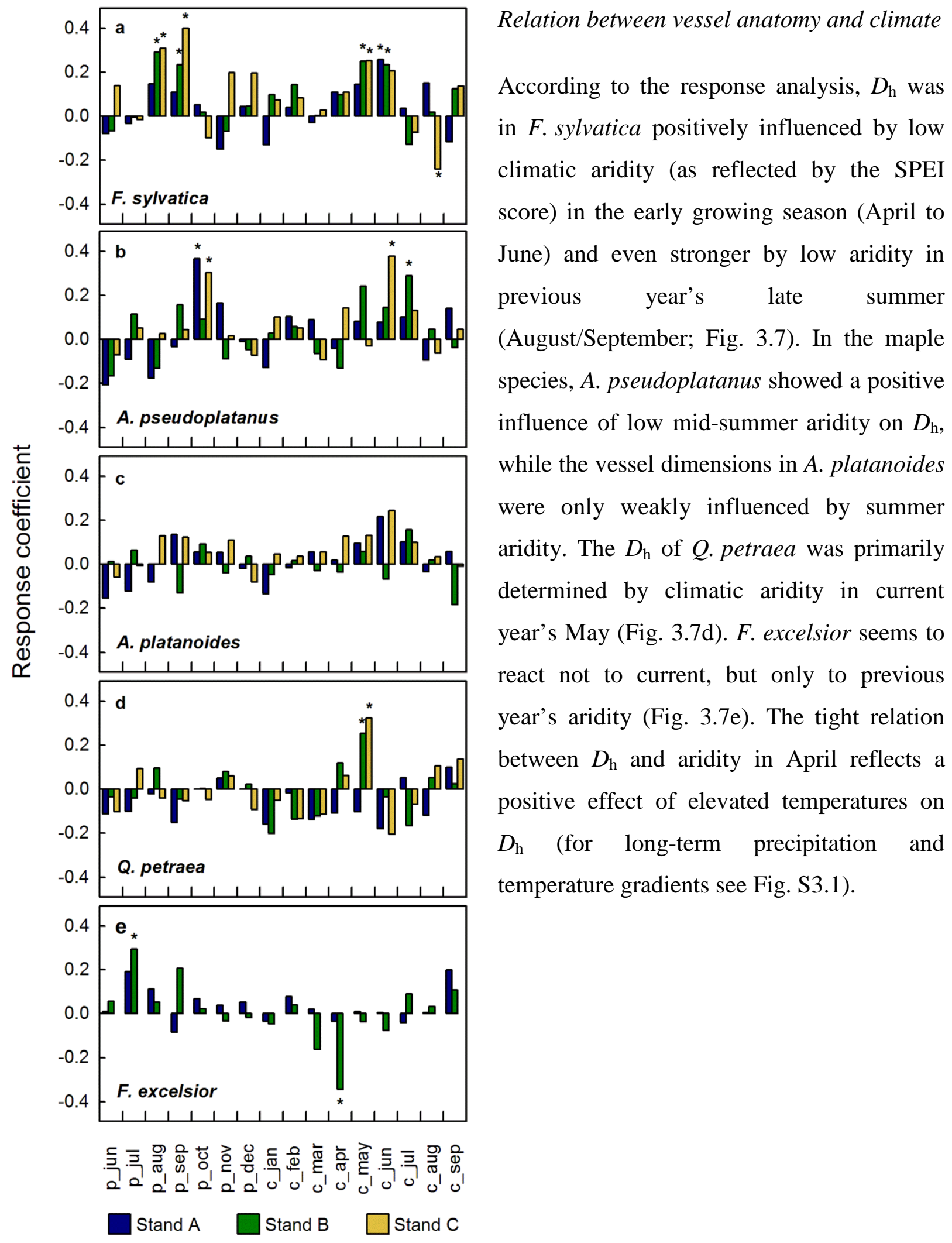

Figure 3.7. Response coefficients of the bootstrapped response function between $D_{\mathrm{h}}$ and SPEI for the five species and three stands from previous year's June to current year's September for the period 1954-2010. Asterisks mark significant coefficients. 


\section{Discussion}

\section{Relationships to tree age}

All investigated species except $F$. sylvatica increased their hydraulically-weighted vessel diameter $\left(D_{\mathrm{h}}\right)$ in the stem xylem by roughly $10 \%$ since 1951 . Even larger than the $D_{\mathrm{h}}$ increase was the age- (or size-) dependent conductivity increase in the most recent tree ring $\left(K_{\mathrm{ann}}\right)$ in the two Acer species, Q. petraea and F. excelsior because these species show a constantly increasing TRW and basal area increment from 1951 to 1980. Increasing vessel size (D) despite increasing summer drought is a strong indication for an important age effect on the hydraulics. In both gymnosperm and angiosperm trees, conduit size at the trunk base generally tends to increase with age, at least during the first years of life (Spicer and Gartner 2001; Christensen-Dalsgaard et al. 2008). In general, trees respond to the higher water demand of an expanding crown and to increasing flow resistances and a larger gravitational force when growing tall with increasing conduit diameters (Lachenbruch et al. 2011). The increase in conduit size, especially during juvenile wood formation, is thought to be a function of cambial ageing (Gartner 1995) and the corresponding auxin concentration during vascular differentiation (Aloni 1987). While in some species, conduit size might increase constantly with age, several studies observed that conduit size either remained constant or that the radial increase in conduit size slowed down after approximately 30 years (Leal et al. 2006; Fan et al. 2009; Leal et al. 2011). The trees in our sample were on average $104 \pm 17$ years old, which means that the first $\sim 40$ years of growth were not captured by our analysis. This might explain the missing trend in F. sylvatica but the mutual relationships between tree age, radial growth, vessel size and both potential $\left(K_{\mathrm{p}}\right)$ as well as annual conductivity $\left(K_{\mathrm{ann}}\right)$ observed in the other four species render this not very likely. Moreover, mature age does not explain the decrease in $D$ by approximately $5 \%$ as observed in $F$. sylvatica at the moistest site (A). A possible explanation could be a relatively high drought sensitivity of the stem cambial activity of beech, which translates into smaller vessels when water is scarce. On the other hand, beech seems to be capable of compensating for smaller vessels by increasing vessel density (VD) and thus to maintain (or even increase) $K_{\mathrm{p}}$ with growing age. This may represent a compromise between the requirements of hydraulic safety and hydraulic efficiency. Such behavior could be part of a strategy of $F$. sylvatica to adapt to precipitation reduction.

\section{Climatic influence on xylem anatomical and hydraulic properties}

Due to the strong increase in $D$ and $K_{\mathrm{p}}$ with age, we restricted the comparison of stands to the last ten growth rings. $D_{\mathrm{h}}$ differed roughly fourfold among diffuse- and ring-porous species, 
VD up to eight- or tenfold, and relative vessel lumen area $\left(A_{\text {lumen }}\right)$ up to threefold. Even larger were the species differences in $K_{\mathrm{p}}$ (up to 30 -fold). In contrast, the site differences in anatomical and hydraulic parameters typically ranged between 1 and 20\% and rarely reached $100 \%$. This result emphasizes the large functional diversity in hydraulic properties, which can exist among different temperate tree species in the same stand. At least in our study, species differences in hydraulic properties were much larger than any site effects.

In comparison across different sites, various studies with a number of tree species have demonstrated a direct effect of plant-available water on wood anatomical properties. Decreasing water availability typically causes the formation of smaller xylem vessels and higher vessel density (Carlquist 1977; Lens et al. 2004; Sterck et al. 2008; Fonti et al. 2013; Chenlemuge et al. 2014). An important consequence is higher resistance to drought-induced xylem embolism (Fonti et al. 2013), achieved at the cost of hydraulic efficiency and growth performance (McDowell 2011) as reflected in narrower annual rings. The assumed strong relationship between water availability and corresponding xylem anatomy is only partly supported by our data. Although we observed a distinct adjustment of anatomical properties to inter-annual change in climatic conditions, modifications in the hydraulic architecture across the precipitation gradient were less clear and rarely significant, which contradicts our first hypothesis. Possible reasons for this result could be the rather short length of our precipitation gradient (roughly $100 \mathrm{~mm} \mathrm{yr}^{-1}$ ), the relatively small sample size $(\mathrm{n}=5)$, and certain differences in soil conditions. Other studies covering longer precipitation gradients found, for example, a close dependence of sapwood area-specific hydraulic conductivity on annual precipitation, both within and between species (Gleason et al. 2012; Gleason et al. 2013; Chenlemuge et al. 2015). Nevertheless, an adaptive anatomical response along our precipitation gradient is visible especially in F. sylvatica (higher vessel density in conjunction with a $~ 5 \%$ smaller mean vessel size), which supports our second hypothesis. An interesting result is also that site-specific modifications in VD often did not translate into site differences in $K_{\mathrm{p}}$ due to an opposite trend in $D_{\mathrm{h}}$. Thus, the tree species of our study seem to produce with a given unit of sapwood area a more or less constant specific hydraulic conductivity across the gradient, independent of water availability.

More relevant for tree functioning and growth than $K_{\mathrm{p}}$ is the cumulative hydraulic conductivity, which a tree is producing annually in the course of radial growth $\left(K_{\mathrm{ann}}\right)$. In the diffuse-porous species, the size of $K_{\text {ann }}$ is primarily determined by differences in annual diameter growth and not by the minor variation observed in $K_{\mathrm{p}}$. Only in $F$. sylvatica, $K_{\mathrm{ann}}$ significantly decreased from the moist to the driest stand to about the half, which indicates 
that water supply to the crown with the formation of new sapwood is deteriorating under reduced precipitation in this species.

The only moderate or small variation in xylem anatomical and hydraulic properties along the precipitation gradient even in the most sensitive species $F$. sylvatica seems to contrast with the significant impact of climate on mean $D_{\mathrm{h}}$ in the annual rings. The climate sensitivity analysis showed significant positive effects of humid spring or early summer weather on $D_{\mathrm{h}}$ in all five species, even though the month of highest sensitivity (May to September) and the decisive year (current or preceding) differed between the species. Interestingly, the conditions of the previous late summer have a stronger influence on $D_{\mathrm{h}}$ than current year conditions in F. sylvatica and to some extent in A. pseudoplatanus and F. excelsior. A similar pattern has been observed for the influence of climate on tree-ring width (Zimmermann et al. 2015), highlighting the close relation between wood production and corresponding xylem anatomy (Chenlemuge et al. 2014; Hajek et al. 2014; Hoeber et al. 2014).

In ring-porous tree species, TRW influences hydraulic traits much less due to the formation of anatomically contrasting early- and latewood. Yet, the climate response of $D_{\mathrm{h}}$ showed a very similar pattern to that of TRW in these species as well. A strong influence of spring or early summer precipitation on $D$ has been found for ring-porous Quercus species (García-González and Eckstein 2003; Fonti and García-González 2008) as well as for diffuse-porous F. sylvatica (Sass and Eckstein 1995); this agrees with our results. Accordingly, trees produce in moist summers sapwood with higher $K_{\mathrm{ann}}$ because mean $D_{\mathrm{h}}$ is larger and the ring is wider, which allows supporting a larger leaf area and maintaining a more favorable leaf water status. This, in turn, increases the carbohydrate supply available for stem growth. Pronounced interannual $D_{\mathrm{h}}$ fluctuation seems to contradict the finding of only minor between-site differences in $D$ along our precipitation gradient, as discussed above. It appears that the individuals of a tree species possess a considerable potential to adapt their crown and root system morphology and hydraulic architecture to the local hydrological conditions, thereby reducing the need of vessel diameter adjustment. Deeper reaching tap roots and a more intense fine root system may be crucial adaptations in this context.

Species differences in hydraulic adaptation and dependence on the species' drought tolerance There is general agreement that vessel size is directly related to cavitation resistance in diffuse-porous tree species (Maherali et al. 2006; Domec et al. 2010; Hajek et al. 2014). We thus assumed that the wood of A.pseudoplatanus is more sensitive to drought than that of A. platanoides and F. sylvatica with smaller mean vessel diameters. Indeed, the branch wood 
of A. pseudoplatanus trees growing in an old-growth forest in Central Germany was found to be more vulnerable to cavitation than that of F. sylvatica and A. platanoides (Schuldt et al., unpublished results). Branch and stem wood anatomy are generally related to each other with species possessing large vessels at the stem base also having large vessel in the branch xylem despite conduit tapering (Schuldt et al. 2013). The cavitation sensitivity ranking of the two Acer species matches the geographical distribution of the species with A.pseudoplatanus generally occurring in more oceanic climates and A.platanoides in more continental ones (Ellenberg and Leuschner 2010). Further, physiological studies and dendrochronological records comparing common Central European broad-leaved tree species suggest that F. sylvatica is more drought sensitive than A.pseudoplatanus (Köcher et al. 2009; Zimmermann et al. 2015). Our findings on stem hydraulic properties are supportive of this ranking because $F$. sylvatica was the only species with a ring-width decline since the $1980 \mathrm{~s}$ (Zimmermann et al. 2015), a concomitant decrease (or lacking increase) in $D_{\mathrm{h}}$ over time, and a significant $K_{\mathrm{ann}}$ decrease in conjunction with a VD increase across the precipitation gradient. This suggests a drought sensitivity ranking in the sequence $F$. sylvatica $>A$. pseudoplatanus $>$ A. platanoides, which is not related to a decrease in mean vessel diameter and implies that the value of $D$ or $D_{\mathrm{h}}$ as drought sensitivity indicators in diffuse-porous species needs further detailed study. It appears that F. sylvatica has developed a considerable plasticity in its hydraulic architecture in a similar manner as this was found for growth processes such as canopy space filling by lateral branch growth or fine root regrowth after stress events (Leuschner et al. 2001; Schröter et al. 2012). During mild drought, this plasticity may represent an advantage over competing species with lower hydraulic plasticity, but it does not counteract the relatively high drought susceptibility which results from traits such as a large meso- to hygromorphic shade leaf area (Legner et al. 2013) or an apparently drought sensitive fine root system (Meier and Leuschner 2008).

Another selecting force during the evolution of tree hydraulic systems is hydraulic efficiency, i.e. the capacity for maximum water transport under conditions of ample moisture availability. Comparison of the five species shows that $K_{\mathrm{p}}$ and also $K_{\mathrm{ann}}$ are about a magnitude larger in the ring-porous than the diffuse-porous species, and $K_{\mathrm{ann}}$ is also greater in F. sylvatica than in the Acer species. However, given that ring-porous species mainly use the youngest ring for water transport (Ellmore and Ewers 1986), the diffuse-porous species with much deeper sapwood can achieve a similarly large, or even higher, stem wood conductance if the number of hydroactive rings is sufficiently large. On the other hand, water storage in the stem as a means of buffering periods of drought stress in the tree canopy is of much greater relevance in 
diffuse- than ring-porous temperate tree species (Betsch et al. 2011; Köcher et al. 2012). In sensitive diffuse-porous species such as F. sylvatica, reduced diameter growth in episodes of drought does not only decrease $K_{\mathrm{ann}}$ and thus canopy water supply, but it also reduces stem water storage, which might eventually result in a downward spiral of reduced hydraulic efficiency and productivity.

Our data highlight the fundamentally different hydraulic systems of diffuse- and ring-porous trees, which are most easily recognized by contrasting vessel diameters and that have implications for growth processes and drought sensitivity. Yet, the functional consequences of these differences are not well understood (McCulloh et al. 2010). By restricting water transport mostly to the current-year growth ring, these species accept the loss of functionality of their highly efficient vessels after periods of severe drought. In accordance with this strategy, both F. excelsior and Q. petraea showed only minor modification of their xylem structure along the precipitation gradient as compared to the diffuse-porous species. Both physiological and dendrochronological studies have revealed a rather low drought sensitivity of these species (e.g. Leuschner et al. 2001; Köcher et al. 2009; Scherrer et al. 2011; Härdtle et al. 2013). One may speculate that modification in the hydraulic architecture is not needed in species that seem to be well adapted to drier environments. More research is needed to understand why ring-porous trees accept the loss of functionality of their large early-wood vessels but still achieve a sufficient degree of hydraulic safety and growth maintenance under drought exposure.

\section{Conclusions}

The hydraulic architecture of trees has attracted much attention in recent time, but most studies are addressing the actual state of the conducting system which is only a snapshot in a tree's life. By combining dendrochronological time-series analysis with the calculation of hydraulic conductivity based on the investigation of xylem anatomy, we were able to reconstruct the development of the trees' stem hydraulic system over six decades and to search for climatic determinants of xylem properties. The comparison of five tree species with different drought sensitivity and ring- or diffuse-porous xylem anatomy revealed an impressive diversity in stem hydraulic properties of the co-existing species. Species differences in radial growth response under exposure to a warmer and drier climate as were reported in a companion study (Zimmermann et al. 2015) were found to be reflected in differing long-term trends in vessel dimensions and hydraulic conductivity. F. sylvatica deviated from the other species not only by a growth decline since the 1980s, but also through 
a stable or decreasing annual production of stem wood conductivity $\left(K_{\mathrm{ann}}\right)$; this should limit canopy expansion in future and may be both cause and consequence of the growth decline.

We conclude that long-term reconstruction of hydraulic properties can add substantially to a mechanistic understanding of tree growth responses to a changing climate. A particularly promising approach for future tree hydraulics research would be to apply the methods outlined here to a larger set of ring- and diffuse-porous tree species in order to compare the drought response of these two functionally different tree groups in a systematic way.

\section{Acknowledgements}

This research was funded by the DFG (Deutsche Forschungsgemeinschaft) within the project GRK 1086 “The role of biodiversity for biogeochemical cycles and biotic interactions in temperate deciduous forests" which is gratefully acknowledged. We thank the DBU (Deutsche Bundesstiftung Umwelt) and the administration of the Biosphere Reserve Karstlandschaft-Südharz for allowing tree coring in their stands. We thank the DWD (Deutscher Wetterdienst, Offenbach) for supplying climate data. We also like to thank Stefan Meyer (Göttingen) for his support during the stand selection phase of the project. 


\section{Supplementary material}

Table S3.1. Mean values and changes in temperature (T) and precipitation (P) during the period 1951-2010 (1954-2010 for temperature) at the four weather-stations in spring (March-May), summer (June-August), autumn (September-November) and winter (December-February).

\begin{tabular}{|c|c|c|c|c|c|}
\hline Weather station & Season & Mean & Change & Regression & $\mathbf{R}^{2} / \mathbf{p}$ \\
\hline \multicolumn{6}{|l|}{ Artern (T) } \\
\hline & Spring & $8.5 \pm 1.1^{\circ} \mathrm{C}$ & $+2.1^{\circ} \mathrm{C}$ & $y=7.44+0.04 x$ & $0.27 /<0.001$ \\
\hline & Summer & $17.3 \pm 1.0^{\circ} \mathrm{C}$ & $+1.8^{\circ} \mathrm{C}$ & $y=16.47+0.03 x$ & $0.25 /<0.001$ \\
\hline & Autumn & $9.2 \pm 1.0^{\circ} \mathrm{C}$ & n.s. & & \\
\hline & Winter & $0.5 \pm 2.2^{\circ} \mathrm{C}$ & $+2.1^{\circ} \mathrm{C}$ & $y=-0.57+0.04 x$ & $0.07 / 0.04$ \\
\hline \multicolumn{6}{|l|}{ Keula (P) } \\
\hline & Spring & $163 \pm 50 \mathrm{~mm}$ & n.s. & & \\
\hline & Summer & $201 \pm 64 \mathrm{~mm}$ & n.s. & & \\
\hline & Autumn & $155 \pm 56 \mathrm{~mm}$ & n.s. & & \\
\hline & Winter & $163 \pm 46 \mathrm{~mm}$ & n.s. & & \\
\hline \multicolumn{6}{|l|}{ Questenberg (P) } \\
\hline & Spring & $150 \pm 48 \mathrm{~mm}$ & n.s & & \\
\hline & Summer & $194 \pm 59 \mathrm{~mm}$ & $-51 \mathrm{~mm}$ & $y=220-0.84 x$ & $0.06 / 0.05$ \\
\hline & Autumn & $149 \pm 53 \mathrm{~mm}$ & $+48 \mathrm{~mm}$ & $y=7.44+0.80 x$ & $0.07 / 0.04$ \\
\hline & Winter & $152 \pm 46 \mathrm{~mm}$ & n.s. & & \\
\hline \multicolumn{6}{|l|}{ Wettelrode (P) } \\
\hline & Spring & $143 \pm 48 \mathrm{~mm}$ & $+47 \mathrm{~mm}$ & $y=119+0.79 x$ & $0.08 / 0.02$ \\
\hline & Summer & $181 \pm 57 \mathrm{~mm}$ & n.s. & & \\
\hline & Autumn & $133 \pm 53 \mathrm{~mm}$ & $+51 \mathrm{~mm}$ & $y=106+0.85 x$ & $0.08 / 0.03$ \\
\hline & Winter & $135 \pm 42 \mathrm{~mm}$ & n.s. & & \\
\hline
\end{tabular}




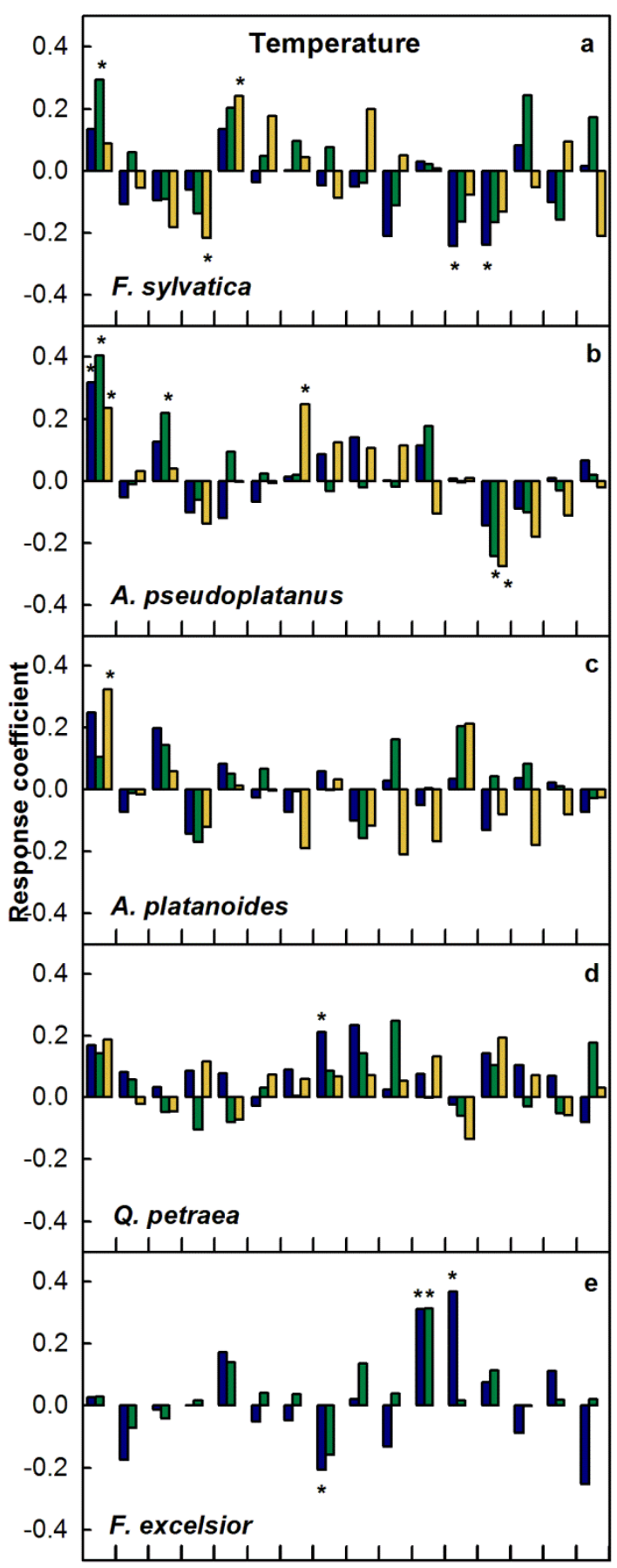

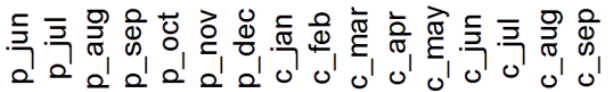

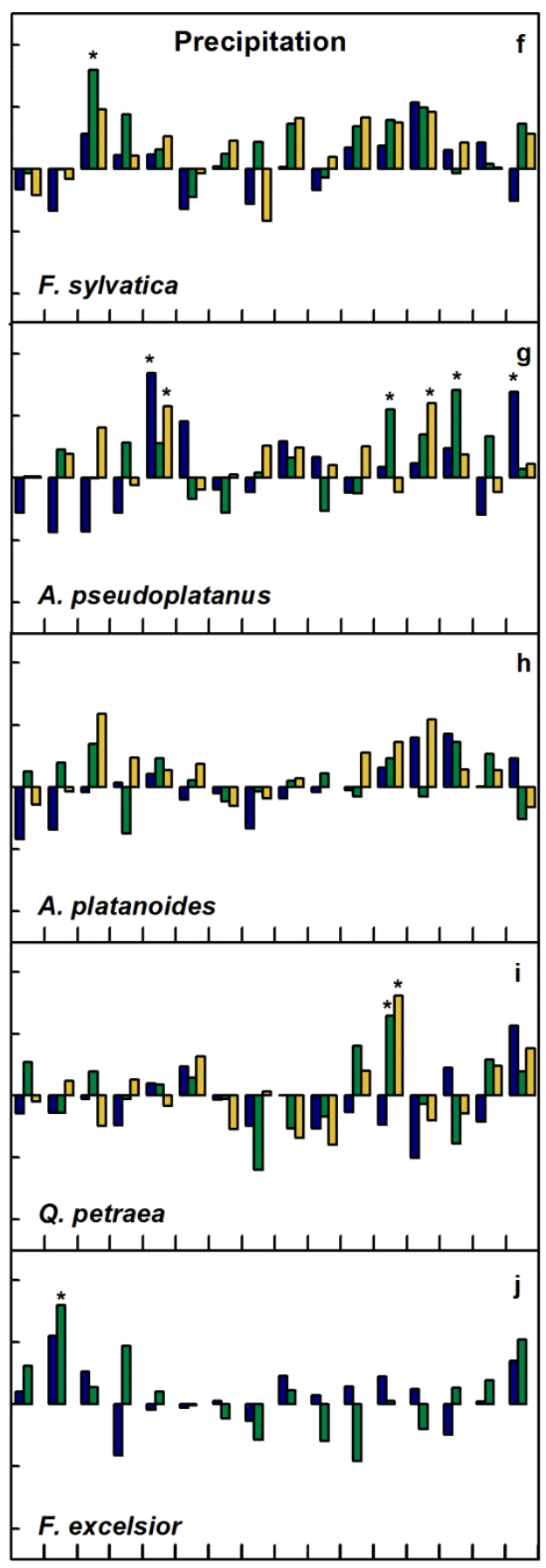

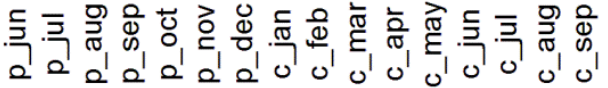

$\square$ Stand A $\square$ Stand B $\square$ Stand C

Figure S3.1: Response coefficients of the bootstrapped response function between $D_{\mathrm{h}}$ and temperature as well as precipitation for the five species and three stands from previous year's June to current year's September for the period 1954-2010. Asterisks mark significant coefficients. 


\section{References}

Allen CD, Macalady AK, Chenchouni H, Bachelet D, McDowell N, Vennetier M Kitzberger T, Rigling A, Breshears DD, Hogg EH, Gonzalez P,Fensham R, Zhang Z, Castro J, Demidova N, Lim JH, Allard G, Running SW, Semerci A, Cobb N. 2010. A global overview of drought and heat-induced tree mortality reveals emerging climate change risks for forests. Forest Ecology and Management 259: 660-684.

Aloni R. 1987. Differentiation of vascular tissues. Annual Review of Plant Physiology and Plant Molecular Biology 38: 179-204.

Ammer C, Albrecht L, Borchert H, Brosinger F, Dittmar C, Elling W, Ewald J, Felbermeier B, von Gilsa H, Huss J, Kenk G, Kölling C, Kohnle U, Meyer P, Mosandl R, Moosmayer HU, Palmer S, Reif A, Rehfuess KE, Stimm B. 2004. Future suitability of beech (Fagus sylvatica L.) in Central Europe: critical remarks concerning a paper of Rennenberg et al. (2004). Allgemeine Forst- und Jagdzeitung 176: 60-67.

Betsch P, Bonal D, Breda N, Montpied P, Peiffer M, Tuzet, A, Granier A. 2011. Drought effects on water relations in beech: The contribution of exchangeable water reservoirs. Agricultural and Forest Meteorology 151: 531-543.

Bolte A, Czajkowski T, Kompa T. 2007. The north-eastern distribution range of European beech a review. Forestry 80: 413-429.

Bréda N, Huc R, Granier A, Dreyer E. 2006. Temperate forest trees and stands under severe drought: a review of ecophysiological responses, adaptation processes and long-term consequences. Annals of Forest Science 63: 625-644.

Cavin L, Mountford PE, Peterken GF, Jump AS. 2013. Extreme drought alters competitive dominance within and between tree species in a mixed forest stand. Functional Ecology 27: 1424-1435.

Carlquist S. 1977. Wood anatomy of Onagraceae - additional species and concepts. Annals of the Missouri Botanical Garden 64: 627-637.

Charru M, Seynave I, Morneau F, Bontemps JD. 2010. Recent changes in forest productivity: An analysis of national forest inventory data for common beech (Fagus sylvatica L.) in north-eastern France. Forest Ecology and Management 260: 864-874.

Chenlemuge T, Schuldt B, Dulamsuren C, Hertel D, Leuschner C, Hauck M. 2014. Stem increment and hydraulic architecture of a boreal conifer (Larix sibirica) under contrasting macroclimates. Trees, doi: 10.1007/s00468-014-1131-x.

Christensen-Dalsgaard KK, Ennos AR, Fournier M. 2008. Are radial changes in vascular anatomy mechanically induced or an ageing process? Evidence from observations on buttressed tree root systems. Trees 22: 543-550. 
Czúcz B, Gálhidy L, Mátyás C. 2011. Present and forecasted xeric climatic limits of beech and sessile oak distribution at low altitudes in Central Europe. Annals of Forest Science 68: 99-108.

Dixon PM 2001 Bootstrap resampling. El-Shaarawi AH, Piegorsch WW, editors. The Encyclopedia of Environmetrics. Wiley, New York p212-220.

Domec JC, Schafer K, Oren R, Kim HS, McCarthy HR. 2010. Variable conductivity and embolism in roots and branches of four contrasting tree species and their impacts on whole-plant hydraulic performance under future atmospheric $\mathrm{CO}_{2}$ concentration. Tree Physiology, 30, 1001-1015.

Dreyer E. 1997. Photosynthesis and drought in forest trees. In: Contributions to Modern Tree Physiology (eds H. Rennenberg, W. Eschrich and H. Ziegler), pp. 215-238. Backhuys Publishers, Netherlands.

Ellmore GS, Ewers FW. 1986. Fluid flow in the outermost xylem increment of a ring-porous tree, Ulmus americana. American Journal of Botany, 73, 1771-1774.

Ellenberg H, Leuschner C. 2010. Vegetation Mitteleuropas mit den Alpen in ökologischer, dynamischer und historischer Sicht. 6th ed. Stuttgart: Ulmer.

Fan ZX, Cao KF, Becker P. 2009. Axial and radial variations in xylem anatomy of angiosperm and conifer trees in Yunnan, China. IAWA Journal, 30, 1-13.

Fonti P, García-González I. 2008. Earlywood vessel size of oak as a potential proxy for spring precipitation in mesic sites. Journal of Biogeography 35: 2249-2257.

Fonti P, Arx G, García-González I, Eilmann B, Sass-Klaassen U, Gärtner H, Eckstein D. 2010. Studying global change through investigation of the plastic responses of xylem anatomy in tree rings. New Phytologist 185: 42-53.

Fonti P, Heller O, Cherubini P, Rigling A, Arend M. 2013. Wood anatomical responses of oak saplings exposed to air warming and soil drought. Plant Biology 15: 210-219.

Gartner B. 1995. Patterns of xylem variation within a tree and their hydraulic and mechanical consequences. In Plant Stems - Physiology and Functional Morphology (eds B Gartner), pp 125-149. Academic Press, San Diego, California.

Gärtner H, Nievergelt D. 2010. The core-microtome: A new tool for surface preparation on cores and time series analysis of varying cell parameters. Dendrochronologia 28: 8592.

Gleason SM, Butler DW, Ziemińska K, Waryszak P, Westoby M. 2012. Stem xylem conductivity is key to plant water balance across Australian angiosperm species. Functional Ecology 26: 343-352. 
Gleason SM, Butler DW, Waryszak P. 2013. Shifts in leaf and stem hydraulic traits across aridity gradients in Eastern Australia. International Journal of Plant Science 174: 1292-1301.

Guiot J. 1991. The bootstrapped response function. Tree-Ring Bulletin 51: 39-41.

Hacke UG, Sperry JS. 2001. Functional and ecological xylem anatomy. Perspectives in Plant Ecology 4: 97-115.

Hajek P, Leuschner C, Hertel D, Delzon S, Schuldt B. 2014. Trade-offs between xylem hydraulic properties, wood anatomy and yield in Populus. Tree Physiology 34: 744756.

Härdtle W, Niemeyer T, Assmann T, Aulinger A, Fichtner A. Lang A, Leuschner C, Neuwirth B, Pfister L, Quante M, Ries C, Shuldt A, Oheimb G. 2013. Climatic responses of tree-ring width and $\delta 13 \mathrm{C}$ signatures of sessile oak (Quercus petraea Liebl.) on soils with contrasting water supply. Plant Ecology 214: 1147-1156.

Herberich E, Sikorski J, Hothorn T. 2010. A robust procedure for comparing multiple menas under heteroscedasticity in unblanced designs. PLOS ONE 5: 1-8.

Hoeber S, Leuschner C, Köhler L, Arias-Aguilar D, Schuldt B. 2014. The importance of hydraulic conductivity and wood density to growth performance in eight tree species from a tropical semi-dry climate. Forest Ecology and Management, 330, 126-136.

Hlásny T, Barcza Z, Fabrika M, Balázs B, Churkina G, Pajtík J, Sedmák R, Turčany M. 2011. Climate change impacts on growth and carbon -balance of forests in Central Europe. Climate Research, 47, 219-236.

IPCC Summary for Policymakers .2013. In Climate Change 2013: The Physical Science Basis. Contribution of Working Group I to the Fifth Assessment Report of the Intergovernmental Panel on Climate Change (eds T.F. Stocker, D. Qin, G.K. Plattner, M. Tignor, S.K. Allen, J. Boschung, ..., P.M. Midgley). Cambridge University Press, Cambridge.

Jacob D. 2009. Regionalisierte Szenarien des Klimawandels. Raumforschung und Raumordnung 67: 89-96.

Jump AS, Hunt JM, Penuelas J. 2006. Rapid climate change-related growth decline at the southern range edge of Fagus sylvatica. Global Change Biology 12: 2163-2174.

Köcher P, Gebauer T, Horna V, Leuschner C. 2009. Leaf water status and stem xylem flux in relation to soil drought in five temperate broad-leaved tree species with contrasting water use strategies. Annals of Forest Science 66: 101.

Köcher P, Horna V, Leuschner C. 2012. Environmental control of daily stem growth patterns in five temperate broad-leaved tree species. Tree Physiology 32: 1021-1032. 
Kramer K, Degen B, Buschbom J, Hickler T, Thuiller W, Sykes MT, Winter W. 2010. Modelling exploration of the future of European beech (Fagus sylvatica L) under climate change-Range abundance genetic diversity and adaptive response. Forest Ecology and Management 259: 2213-2222.

Lachenbruch B, Moore J, Evans R. 2011. Radial variation in wood structure and function in woody plants and hypotheses for its occurrence. In: Size and Age-Related Changes in Tree Structure and Function (eds FC Meinzer B Lachenbruch TE Dawson) pp. 121164 Springer Dordrecht.

Leal S, Sousa VB, Pereira H. 2006. Radial variation of vessel size and distribution in cork oak wood (Quercus suber L.). Wood Science and Technology 41: 339-350.

Leal S, Sousa VB, Knapic S, Louzada JL, Pereira H. 2011. Vessel size and number are contributors to define wood density in cork oak. European Journal of Forest Research 130: 1023-1029.

Legner N, Fleck S, Leuschner C. 2013 Low light acclimation in five temperate broad-leaved tree species of different successional status: the significance of a shade canopy. Annals of Forest Science 70: 557-570.

Lens F, Luteyn JL, Smets E, Jansen S. 2004. Ecological trends in the wood anatomy of Vaccinioideae (Ericaceae sl) Flora 199: 309-319.

Leuschner C, Backes K, Hertel D, Schipka F, Schmitt U, Terborg O, Runge M. 2001. Drought responses at leaf stem and fine root levels of competitive Fagus sylvatica L. and Quercus petraea (Matt) Liebl. trees in dry and wet years. Forest Ecology and Management 149: 33-46.

Lindner M, Maroschek M, Netherer S, Kremer A, Barbati A, Garcia-Gonzalo J, Seidl R, Delzon S, Corona P, Kolström M, Lexer M, Marchetti M. 2010. Climate change impacts adaptive capacity and vulnerability of European forest ecosystems. Forest Ecology and Management 259: 698-709.

Maherali, H Pockman, WT, Jackson RB. 2004. Adaptive variation in the vulnerability of woody plants to xylem cavitation. Ecology 85: 2184-2199

Maherali H, Moura CF, Caldeira MC, Willson CJ, Jackson RB. 2006. Functional coordination between leaf gas exchange and vulnerability to xylem cavitation in temperate forest trees. Plant Cell Environment 29: 571-583.

McCulloh KA, Sperry JS, Lachenbruch B, Meinzer FC, Reich PB, Voelker S. 2010. Moving water well: comparing hydraulic efficiency in twigs and trunks of coniferous ringporous and diffuse-porous saplings from temperate and tropical forests. New Phytologist 186: 439-450. 
McDowell NG. 2011. Mechanisms linking drought hydraulics carbon metabolism and vegetation mortality Plant Physiology 155: 1051-1059.

Meier IC, Leuschner C. 2008. Leaf size and leaf area index in Fagus sylvatica Forests: Competing effects of precipitation temperature and nitrogen availability. Ecosystems 11: 655-669.

Mette T, Dolos K, Meinardus C, Bräuning A, Reineking B, Blaschke M, Pretzsch H, Beierkuhnlein C, Gohlke A, Wellstein C. 2013. Climate turning point for beech and oak under climate change in Central Europe. Ecosphere 4: 1-19.

Piovesan G, Biondi F, Di Fillipo A, Maugeri M. 2008. Drought-driven growth reduction in old beech (Fagus sylvatica L) forests of the central Apennines Italy. Global Change Biology 14: 1265-1281.

R Development Core Team. 2008. R: A language and environment for statistical computing R Foundation for Statistical Computing Vienna Austria ISBN 3-900051-07-0 URL http://wwwR-projectorg.

Rennenberg H, Seiler W, Matyssek R, Gessler A, Kreuzwieser J. 2004. European beech (Fagus sylvatica L.) - a forest tree without future in the south of Central Europe? Allgemeine Forst- und Jagdzeitung 175: 210-224.

Rose L, Leuschner C, Köckemann B, Buschmann H. 2009. Are marginal beech (Fagus sylvatica L.) provenances a source for drought tolerant ecotypes? European Journal of Forest Research 128: 335-343.

Sass U, Eckstein D. 1995. The variability of vessel size in beech (Fagus sylvatica L) and its ecophysiological interpretation. Trees 9: 247-252.

Schär C, Vidale PL, Lüthi D, Frei C, Häberli C, Liniger MA, Appenzeller C. 2004. The role of increasing temperature variability in European summer heatwaves. Nature 427: 332-336.

Scharnweber T, Manthey M, Criegee C, Bauwe A, Schröder A, Wilmking M. 2011. Drought matters - Declining precipitation influences growth of Fagus sylvatica L. and Quercus robur L. in north-eastern Germany. Forest Ecology and Management 262: 947-961.

Scherrer D, Bader KFB, Körner C. 2011. Drought-sensitivity ranking of deciduous tree species based on thermal imaging of forest canopies. Agriculture and Forest Meteorology 151: 1632-1640.

Schröter M, Hardtle W, von Oheimb G .2012. Crown plasticity and neighborhood interactions of European beech (Fagus sylvatica L.) in an old-growth forest. European Journal of Forest Research 131: 787-798. 
Schuldt B, Leuschner C, Brock N, Horna V. 2013. Changes in wood density wood anatomy and hydraulic properties of the xylem along the root-to-shoot flow path in tropical rainforest trees. Tree Physiology 33: 161-74.

Sperry JS, Nichols KL, Sullivan JEM, Eastlack SE. 1994. Xylem embolism in ring-porous diffuse-porous and coniferous trees of northern Utah and interior Alaska. Ecology 75 : 1736-1752.

Spicer R, Gartner BL. 2001. The effects of cambial age and position within the stem on specific conductivity in Douglas-fir (Pseudotsuga menziesii) sapwood. Trees 15: 222229.

Sterck FJ, Zweifel R, Sass-Klaassen U, Chowdhury Q. 2008. Persisting soil drought reduces leaf specific conductivity in Scots pine (Pinus sylvestris) and pubescent oak (Quercus pubescens). Tree Physiology 28: 529-536.

Thornthwaite CW. 1948. An approach toward a rational classification of climate. Geographical Review 38: 55-94.

VFS (2005) Waldökologische Naturräume Deutschlands. Mitteilungen des Vereins für Forstliche Standortskunde und Forstpflanzenzüchtung 43.

Vincente-Serrano SM Begueria S Lopez-Moreno JI. 2009. A multiscalar drought index sensitive to global warming: The standardized precipitation evapotranspiration index. Journal of Climate 23: 1696-1718.

White FM. 1991. Viscous Fluid Flow McGraw-Hill New York.

Wortemann R, Herbette S, Barigah TS, Fumanal B, Alia R, Ducousso A, Gomoray D, Roeckel-Drevet P, Cochard H. 2011. Genotypic variability and phenotypic plasticity of cavitation resistance in Fagus sylvatica L. across Europe Tree Physiology 31 11751182.

Zang C, Biondi F. 2013. Dendroclimatic calibration in R: The bootRes package for response and correlation function analysis. Dendrochronologia 31: 68-74.

Zimmermann J, Hauck M, Dulamsuren C, Leuschner C. 2015. Climate warming-related growth decline affects Fagus sylvatica but not other broad-leaved tree species in Central European mixed forests. Ecosystems DOI: 101007/s10021-015-9849-x. 


\section{Chapter 4}

\section{Drought alters the competitive hierarchy within tree populations and among different species in temperate broad-leaved mixed forests}

Jorma Zimmermann • Markus Hauck • Christoph Leuschner 



\begin{abstract}
Mixed forests are thought to be less susceptible to climate warming-related drought than pure stands because species diversity may buffer against vigor loss caused by the sensitivity of individual species. Severe drought events will hit different species and individuals within populations differently, potentially causing shifts in forest community composition. We investigated long-term radial growth trends and the resilience of growth after extreme drought events in four co-occurring tree species (Fagus sylvatica, Acer pseudoplatanus, Quercus petraea, Fraxinus excelsior) in mixed stands and asked how resilience depends on tree size, age and the species composition of the tree's neighborhood. We hypothesized that extreme drought events trigger not only shifts in species composition but also in the intraspecific population structure and that tree size and the species identity of the neighbors have a considerable influence on the trees' drought response. In large-sized Fagus trees (DBH >30 $\mathrm{cm}$ ), radial increment was found to decline since around 1980. In all species, growth resilience after two extreme drought events was negatively related to $\mathrm{DBH}$. The higher sensitivity of large-diameter trees results in a shift in intra- as well as interspecific population structure with smaller, less competitive trees surpassing larger dominant trees in radial increment in the decades after a severe drought. While neighborhood diversity had no effect on the resilience of growth, neighbor identity mattered in several cases. We conclude that extreme droughts represent an important structuring force in temperate mixed forests that trigger dynamic change in the population structure of the species and also in species composition.
\end{abstract}

Key words: Acer, climate warming, Fagus, Fraxinus, growth decline, growth resilience, neighborhood composition, population dynamics, Quercus 


\section{Introduction}

With global warming, many forests of the temperate zone are increasingly exposed to drought and high summer temperatures which may threaten their vitality and productivity (Allen et al., 2010). Recent research efforts have been addressing two major questions, (i) what morphological and physiological traits are determining a tree's susceptibility to drought (Breda et al., 2006; Valladares and Sánchez-Gómez, 2006; Köcher et al., 2013), and (ii) how foresters can mitigate the impact of drought on forests by adapting forest structure and composition. Forest management options include the selection of drought-tolerant provenances (Peuke et al., 2006; Bolte et al., 2007; Rose et al., 2009) and species, reducing stem density to lower competition intensity for water (Amato et al., 2013; Sohn et al., 2013), and the establishment of mixed stands. In accordance with the insurance hypothesis of biodiversity (Yachi and Loreau, 1999), it is predicted that mixed forests should respond to severe droughts with higher resilience than monospecific forests, when the community includes one or more species with a higher drought tolerance which can replace more sensitive species in the course of forest succession. Such a diversity effect may increase the long-term stability of natural non-managed forests and thus be important in terms of forest continuity, but it is of low relevance for production forests and tree plantations. Foresters are more interested in possible beneficial effects of allospecific neighbors on target trees as they have been observed in mixed forests, for example, in the case of F. sylvatica when planted in mixture with Picea abies or Quercus petraea (Pretzsch and Schütze, 2009; Pretzsch et al. 2012). Mölder et al. (2014) found trees of Fagus sylvatica in a mixed broad-leaved forest to be more drought-tolerant when growing in a heterospecific neighbourhood as when growing together with other beech trees. The latter authors assumed that the positive mixing effect on F. sylvatica resulted from a lower water consumption of the heterospecific neighbor trees than of beech itself. Whether trees are profiting from mixture under drought should largely depend on the species and may vary with site conditions. Apart from the situation where mixed forests exploit larger soil volumes for water than monocultures, there should always be species in mixtures that either grow better or worse under drought compared to monoculture, depending on the relative intensity of interspecific and intraspecific competition.

Drought could not only alter the species composition of mixed forests, but may also shift dominance patterns within tree populations by affecting different size or age classes of species differently. Large, dominant trees have repeatedly been found to be more susceptible to drought events, with the result of a shift in the intra- as well as interspecific dominance pattern in mixed forests (Mueller et al., 2005; Cavin et al., 2013; Rodríguez-Catón et al., 
2015). As interspecific and intraspecific competition most often are asymmetric (Canham et al., 2006), the interaction between trees of different species and sizes inevitably leads to shifts in the dominance patterns within populations and among species in mixed stands. This process is driven by the complex interplay of tree size and age, species-specific resource use patterns, and species richness, factors that determine competition for water and other resources in drought-affected mixed stands. Ultimately, these interactions determine the fate of tree individuals and species in the mixture and the future development of the stand in a drier climate.

This study is an attempt to unravel the combined effects of tree size, age and growth rate, species identity, and neighborhood constellation on a tree's response to drought. It bases on the results of an earlier dendroclimatological study (Zimmermann et al., 2015) in three mixed forests along a precipitation gradient which consisted of five broad-leaved tree species of which four are further investigated in this study. This study revealed that Fagus sylvatica L. (European beech) is more susceptible to drought than the three other co-occurring tree species. Beech, but not the other species, showed a decline in radial increment since about 1980 in the driest stand, which was explained by increasing summer drought and rising summer temperatures during the last decades. While this growth decline was most pronounced in the driest stand, where it was found in all examined beech trees, certain individuals in the moister stands showed a similar declining growth trend as well. This raises the question which individuals of a F. sylvatica population are particularly sensitive to drought and what tree properties and environmental conditions are responsible for this sensitivity. We searched for dendrochronological evidence that exceptional drought events enhance asymmetric competition between different tree species and also between different tree individuals of a species in mixed stands. The main vitality parameters considered were long-term radial growth trends and growth resilience in response to extreme multi-year drought events. We hypothesized that (i) extreme drought events have a large impact on the competitive hierarchy of mixed forests by triggering divergence in growth trends of cooccurring species, (ii) these extreme events also trigger shifts in the dominance structure within tree populations, (iii) trees with large diameters are particularly sensitive to extreme droughts, independent of species, and (iv) the tree's response depends also on the species composition of the neighborhood, while species diversity in the stand is of minor importance. 


\section{Material and methods}

Study area and sampled stands

We investigated the radial growth patterns of four broad-leaved tree species of the genera Fagus, Quercus, Acer and Fraxinus in three mixed forests in the Triassic uplands of southwestern Saxony-Anhalt and northern Thuringia in central Germany (see chapter 2: Fig. 2.1). In this region in the transition zone between a sub-oceanic climate in the West and a more sub-continental climate in the East in the rain shadow of the Harz Mountains, European beech (Fagus sylvatica), the dominant tree species of natural forest vegetation in large parts of Central Europe, occurs close to its drought-induced limit (Ellenberg and Leuschner, 2010). Due to reduced competitive superiority, F. sylvatica here often co-occurs with other more drought-tolerant broad-leaved trees such as Quercus petraea Matt. Liebl., Acer pseudoplatanus L. and A. platanoides L., Fraxinus excelsior L., Tilia cordata L.and Carpinus betulus L. (Köcher et al., 2009; Scherrer et al., 2011). We selected four species which are moderately or highly important for forestry, that contrast with respect to hydraulic architecture (diffuse-porous vs. ring-porous), mycorrhiza type (ectomycorrhizal vs. arbuscular mycorrhizal) and assumed sensitivity to drought (low to moderate vs. high) (Köcher et al. 2009; Lang et al., 2011; Scherrer et al., 2011; Lübbe et al., unpublished data): Sycamore maple (A.pseudoplatanus), sessile oak (Q.petraea), European ash (F.excelsior), and F. sylvatica (Table 4.1).

Table 4.1. Some properties of the four studied tree species.

\begin{tabular}{lcccc}
\hline & $\begin{array}{c}\text { Fagus } \\
\text { sylvatica }\end{array}$ & $\begin{array}{c}\text { Acer } \\
\text { pseudoplatanus }\end{array}$ & $\begin{array}{c}\text { Quercus } \\
\text { petraea }\end{array}$ & $\begin{array}{c}\text { Fraxinus } \\
\text { excelsior }\end{array}$ \\
\hline Family & Fagaceae & Aceraceae & Fagaceae & Oleaceae \\
$\begin{array}{l}\text { Position in } \\
\text { succession }\end{array}$ & $\begin{array}{c}\text { late- } \\
\text { successional }\end{array}$ & $\begin{array}{c}\text { mid- to late- } \\
\text { successional }\end{array}$ & $\begin{array}{c}\text { mid- to late- } \\
\text { Successional }\end{array}$ & $\begin{array}{c}\text { early- to mid- } \\
\text { successional }\end{array}$ \\
$\begin{array}{l}\text { Mycorrhiza } \\
\text { type }\end{array}$ & ECM & AM & ECM & AM \\
$\begin{array}{l}\text { Xylem } \\
\text { anatomy }\end{array}$ & diffuse-porous & diffuse-porous & ring-porous & ring-porous \\
$\begin{array}{l}\text { Assumed drought } \\
\text { sensitivity }\end{array}$ & high & moderate to high & low to moderate & low to moderate \\
\hline
\end{tabular}


The three stands (A, B and C) are located at elevations between 250 and $450 \mathrm{~m}$ and differ in mean annual precipitation (MAP), which decreases along a $50 \mathrm{~km}-$ long transect in west-east direction from 685 to $590 \mathrm{~mm} \mathrm{yr}^{-1}$ (Deutscher Wetterdienst, Offenbach, Germany; Fig. 2.1). The gradient represents the assumed transition zone from a beech-dominated forest in a suboceanic climate to a mixed forest under a summer-dry sub-continental climate (see chapter 2: Table 2.1). Two stands were located on Triassic limestone (A and C) and one on pellite rock. Stand C had a particularly steep slope and at some places igneous rock built the bedrock, with beech typically growing on the shallower limestone and oak on the deeper igneous rock soils. In this stand, wood cores were taken for all species on both soil types.

\section{Climate data}

In the neighborhood of all three stands, weather stations recording precipitation were available (Fig 2.1). Gaps in the precipitation data of Stand B and C were interpolated using data from other stations. Drought intensity was quantified with the standardized precipitationevapotranspiration index (SPEI) (Vincente-Serrano et al., 2010). The SPEI was calculated with R software v. 2.15 (R Development Core Team, 2012) using the R-package 'SPEI' v. 1.6. For the calculation, monthly precipitation and potential evapotranspiration (PET) data were used. PET was calculated with the Thornthwaite method (Thornthwaite, 1948) using monthly mean temperature and a correlation coefficient derived from latitude to calculate day length. SPEI was calculated on a monthly timescale using indices with a log-logistic probability distribution and parameter fitting based on unbiased probability-weighted moments.

\section{Selection of tree individuals}

In 2011, 18-20 trees per species and stand were selected. Due to their lower abundance, only 14-16 trees of A.pseudoplatanus could be examined. In stand C, no individuals of F. excelsior were present. All selected trees were part of the upper canopy. They had diameters of 35-66 cm with the exception of Q. petraea in stands A and B with diameters of up to $75 \mathrm{~cm}$.

A neighborhood analysis was conducted in the 'influence sphere' of the target trees which was delimitated by a cone with an angle of $60^{\circ}$ turned upside down with the apex being positioned at $60 \%$ tree height. All trees whose crowns were present in the cone were considered as neighbors. For every neighbor, species identity, diameter at breast height $(\mathrm{DBH})$, tree height as well as distance to the target tree were recorded. The tree diversity in 
the influence sphere was expressed with Shannon's diversity index (H') (Spellerberg and Fedor, 2003). While effects of neighborhood diversity were examined across species, effects of species identity were examined for every species separately.

\section{Wood core sampling and analysis of tree-ring data}

Each one wood core per tree was collected from every target tree from July to October 2011. Samples were taken at breast height $(1.3 \mathrm{~m})$ with an increment borer of $5 \mathrm{~mm}$ inner diameter (Haglöf, Langsele, Sweden) in the direction where the least influence of tension wood was to be expected. Tree-ring width was measured with a precision of $10 \mu \mathrm{m}$ on a movable object table (Lintab 5, Rinntech, Heidelberg, Germany) using the software TSAP-Win v. 4.67c (Rinntech).

The tree-ring data were analyzed with TSAP-Win software. Cross-dating was based on the coefficient of agreement (GL, 'Gleichläufigkeit'; Eckstein and Bauch, 1969) and t-values (Baillie and Pilcher, 1973). The DBH of the trees for any given year was reconstructed on the basis of the tree ring widths. Resilience (Rs) of radial growth to drought events was calculated after Lloret et al. (2001) using the expression $R s=r_{\text {post }} / r_{\text {pre }}$ with $r_{\text {post }}$ being the increment after and $r_{\text {pre }}$ the increment before that drought event. $r_{\text {post }}$ and $r_{\text {pre }}$ base on increment averages for the 10-yr periods before and after a drought event because we wanted to cover the whole medium-term increment recovery process and not only the immediate stress release. In two cases, a tree of A. pseuoplatanus produced an exceptionally high Rs-value (4.5 and 11), due to very low increment prior the drought and a sudden growth release after the event. These outliers were excluded from the regression analyses.

\section{Statistical analysis}

Arithmetic means \pm SD are presented throughout the paper. All data sets were tested for normal distribution with the Shapiro-Wilk test. Homogeneity of variances was tested with Levene's test. Significant differences between the means of groups were tested either with Welch's t-test (at normal distribution) or the Mann-Whitney U test. Hierarchical clustering using Ward's method (Ward, 1963) was applied to identify distinct groups of trees with different growth trends (2 groups per species and stand) using the statistical software PAST 2.16 (Hammer et al., 2001).

In multiple regression analyses Akaike's information criterion (AIC) was used to determine if a model was improved over a basic model by including additional independent variables. The Durbin Watson test was used to detect autocorrelation in the residuals of the regression 
analysis, as was the variance inflation factor (VIF) to test for multi-collinearity. The influence of data points was tested using Cook's distance $\left(D_{i}\right)$, with $D_{i} \geq 1$ marking highly influential points. All statistical analyses except the cluster analysis were calculated with R 2.15 software (R Development Core Team, 2012). A significance level of $\alpha \leq 0.05$ was used throughout the study.

\section{Results}

Growth trends related to drought

In the investigated period from 1951-2010, two major drought events spanning more than one

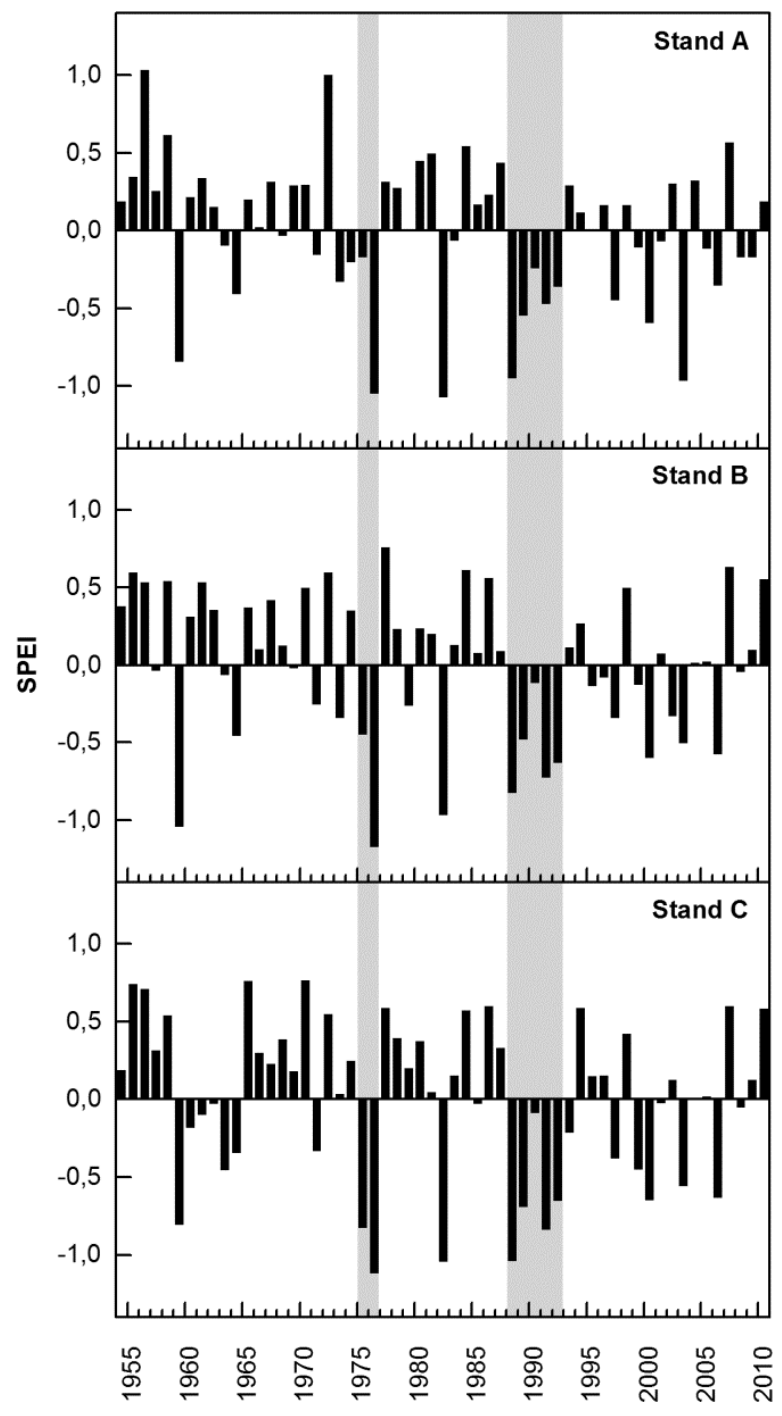

Figure 4.1. Mean standardized precipitation evapotranspiration index (SPEI) of the growing season (April-September) for the stands A-C in the period 1954-2010. SPEI was calculated after Vincente-Serrano et al. (2010) as the difference between precipitation and potential evapotranspiration. Negative values indicate water deficits. year hit the three stands. The first occurred in the years 1975/76 (drought event I) and the second in the years from 1988 to 1992 (drought event II, Fig. 4.1) which had distinct effects on radial growth. While there were additional drought years like 1959, 1983 and 2003, those droughts were limited to a few months of a single year and not as influential as the mentioned events.

The effect of these drought events was visible in all four investigated species, not only in a short-term (<10 years) and/or long-term decrease ( $>10$ years) in increment, but in many cases also in a shift of the competitive hierarchy in the stands. Based on the cluster analysis, each two groups of trees with different growth performance over time were identified in all four species, one group with superior growth in the past and growth decline after one of the two major drought events (gD) and a second group with relatively low increment in the past and a growth increase (or maintenance) after one of the drought events (gI). In the long run, the gI group exceeded the gD group in its annual increment (Fig. 4.2), in 
particular after 1980. Other event years not related to a drought as, for example, 1996 also seem to play an important role in some cases of within-population growth shifts, but they will not be investigated further in this study.

This pattern of shifting dominance was most distinct in F. sylvatica and less clearly visible in the other three species, where the increment of the two groups was often very similar until a drought event triggered the different development of the gD and gI populations. This observation is supported by the basal area increment data of the gD and gI groups before the 1974 drought event (first phase), between the 1974 and 1988 events (second phase), and after the 1988 to 1992 event (third phase) in Table 4.2.
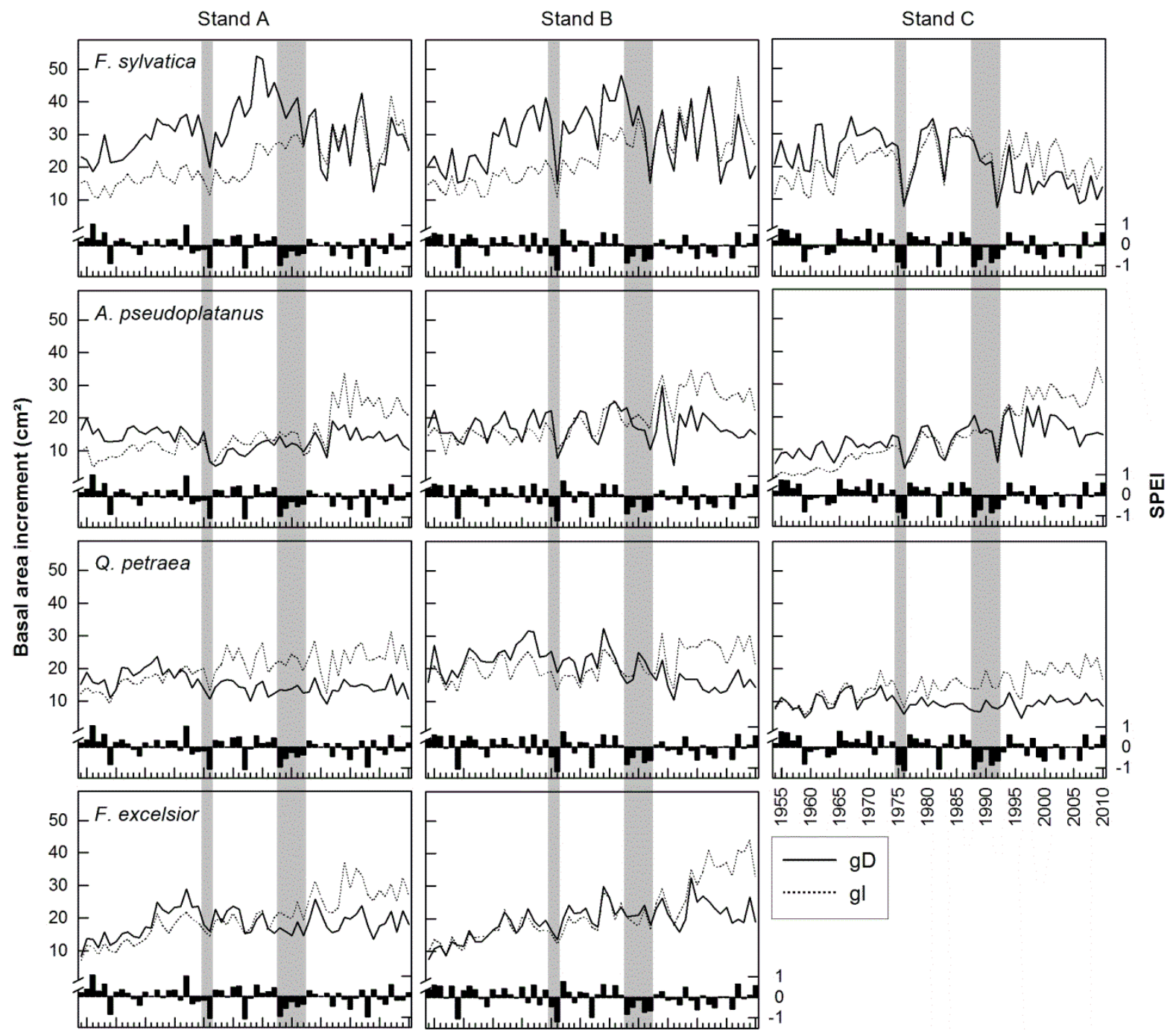

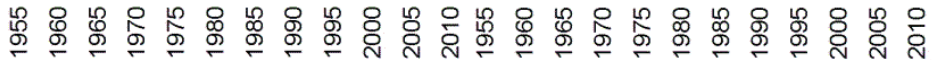

Figure 4.2. Basal area increment (BAI) of the each two tree populations (gD and gI) of a species in the three stands as obtained with a cluster analysis. Standardized precipitation-evapotranspiration indices (SPEI) are also depicted (bars) to visualize variation in drought intensity during the study period. 
In nearly all cases, the gI trees had lower or similar growth rates during the first phase, but growth exceeded that of the gD population in the third phase (difference significant in the majority of cases). Whether growth declined or increased (or was maintained) depended on $\mathrm{DBH}$. This is shown for the beech trees in the driest stand C: all trees with $\mathrm{DBH}<30 \mathrm{~cm}$ in 1980 showed a positive growth trend in the decades thereafter, whereas trees with larger DBH either belonged to the gD or the gI group (Fig. 4.3). Nevertheless, the two populations of beech (or of other species) with different growth performance had the same age (except for the Acer trees in stand B and Quercus trees in stand C) and did not differ with respect to neighborhood diversity for the gD and gI groups of a species (see below).

Table 4.2. Some characteristics of the two tree populations of a species with different growth characteristics gD and gI as found in the cluster analysis. N: number of trees per population, Age: mean tree age at breast height, DBH: mean diameter at breast height, BAI: mean basal area increment, MS: mean sensitivity of growth, CI: mean competition index after Hegyi for the tree neighborhood, Shannon: mean Shannon diversity index for the tree neighborhood. Different uppercase letters indicate significant $(\mathrm{p}<0.05)$ differences between the gD and gI populations of a species in a given stand (Mann-Whitney U test).

\begin{tabular}{|c|c|c|c|c|c|c|c|c|c|c|c|}
\hline Species & Stand & Group & $\mathbf{N}$ & Age & DBH 74 & DBH 87 & DBH 10 & $\begin{array}{c}\text { BAI } \\
54-74 \\
\end{array}$ & $\begin{array}{c}\text { BAI } \\
77-87 \\
\end{array}$ & $\begin{array}{c}\text { BAI } \\
93-10 \\
\end{array}$ & Shannon \\
\hline \multirow{6}{*}{ F. sylvatica } & & $\mathrm{gD}$ & 7 & $95 \pm 12^{\mathrm{a}}$ & $34.0 \pm 3.7^{\mathrm{a}}$ & $41.9 \pm 5.3^{\mathrm{a}}$ & $54.9 \pm 6.1^{\mathrm{a}}$ & $26.9 \pm 6.7^{\mathrm{a}}$ & $39.5 \pm 16.2^{\mathrm{a}}$ & $27.7 \pm 7.1^{\mathrm{a}}$ & $0.27 \pm 0.33^{\mathrm{a}}$ \\
\hline & & gI & 13 & $95 \pm 12^{\mathrm{a}}$ & $26.8 \pm 5.2^{\mathrm{b}}$ & $32.2 \pm 5.4^{\mathrm{b}}$ & $47.5 \pm 4.1^{\mathrm{b}}$ & $15.8 \pm 5.2^{\mathrm{b}}$ & $20.3 \pm 6.9^{\mathrm{b}}$ & $29.1 \pm 8.5^{\mathrm{a}}$ & $0.39 \pm 0.35^{\mathrm{a}}$ \\
\hline & \multirow[b]{2}{*}{$E$} & gD & 9 & $98 \pm 18^{\mathrm{a}}$ & $33.1 \pm 3.7^{\mathrm{a}}$ & $40.1 \pm 3.8^{\mathrm{a}}$ & $55.6 \pm 3.1^{\mathrm{a}}$ & $25.6 \pm 3.7^{\mathrm{a}}$ & $36.7 \pm 10.7^{\mathrm{a}}$ & $28.3 \pm 8.1^{\mathrm{a}}$ & $0.59 \pm 0.31^{\mathrm{a}}$ \\
\hline & & gI & 11 & $101 \pm 8^{\mathrm{a}}$ & $27.1 \pm 5.2^{\mathrm{b}}$ & $33.2 \pm 6.1^{\mathrm{b}}$ & $52.6 \pm 7.2^{\mathrm{b}}$ & $15.7 \pm 5.1^{\mathrm{b}}$ & $24.2 \pm 12.3^{\mathrm{b}}$ & $31.9 \pm 13.6^{\mathrm{a}}$ & $0.46 \pm 0.34^{\mathrm{a}}$ \\
\hline & \multirow{2}{*}{$C$} & gD & 6 & $109 \pm 8^{\mathrm{a}}$ & $36.3 \pm 6.2^{\mathrm{a}}$ & $41.7 \pm 6.2^{\mathrm{a}}$ & $52.4 \pm 5.7^{\mathrm{a}}$ & $24.3 \pm 4.4^{\mathrm{a}}$ & $25.7 \pm 2.6^{\mathrm{a}}$ & $16.8 \pm 7.9^{\mathrm{a}}$ & $0.32 \pm 0.41^{\mathrm{a}}$ \\
\hline & & gI & 14 & $101 \pm 14^{\mathrm{a}}$ & $29.0 \pm 8.3^{b}$ & $35.2 \pm 8.1^{\mathrm{a}}$ & $46.4 \pm 7.3^{\mathrm{a}}$ & $19.7 \pm 9.7^{\mathrm{a}}$ & $26.2 \pm 8.1^{\mathrm{a}}$ & $21.3 \pm 6.9^{\mathrm{a}}$ & $0.45 \pm 0.42^{\mathrm{a}}$ \\
\hline \multirow{6}{*}{$\begin{array}{l}\text { A. pseudo- } \\
\text { platanus }\end{array}$} & \multirow[b]{2}{*}{ A } & gD & 8 & $92 \pm 8^{\mathrm{a}}$ & $27.5 \pm 4.1^{\text {a }}$ & $30.4 \pm 4.4^{\mathrm{a}}$ & $43.4 \pm 6.0^{\mathrm{a}}$ & $15.3 \pm 4.8^{\mathrm{a}}$ & $9.9 \pm 4.5^{\mathrm{a}}$ & $14.1 \pm 4.5^{\mathrm{a}}$ & $0.73 \pm 0.24^{\mathrm{a}}$ \\
\hline & & gI & 8 & $99 \pm 13^{\mathrm{a}}$ & $26.0 \pm 6.7^{\mathrm{a}}$ & $29.5 \pm 7.3^{\mathrm{a}}$ & $50.3 \pm 5.5^{\mathrm{b}}$ & $9.9 \pm 4.2^{\mathrm{b}}$ & $12.4 \pm 6.1^{\mathrm{a}}$ & $22.3 \pm 7.9^{\mathrm{b}}$ & $0.91 \pm 0.26^{\mathrm{a}}$ \\
\hline & \multirow{2}{*}{ B } & gD & 12 & $121 \pm 23^{\mathrm{a}}$ & $32.8 \pm 6.3^{\mathrm{a}}$ & $37.2 \pm 6.0^{\mathrm{a}}$ & $51.5 \pm 6.4^{\mathrm{a}}$ & $17.7 \pm 6.2^{\mathrm{a}}$ & $18.6 \pm 4.3^{\mathrm{a}}$ & $17.2 \pm 5.5^{\mathrm{a}}$ & $0.77 \pm 0.20^{\mathrm{a}}$ \\
\hline & & gI & 4 & $94 \pm 11^{\mathrm{b}}$ & $26.5 \pm 2.1^{\mathrm{b}}$ & $31.6 \pm 2.0^{\mathrm{b}}$ & $52.8 \pm 6.0^{\mathrm{a}}$ & $14.8 \pm 1.8^{\mathrm{a}}$ & $18.6 \pm 4.8^{\mathrm{a}}$ & $28.0 \pm 5.6^{\mathrm{b}}$ & $1.04 \pm 0.26^{\mathrm{a}}$ \\
\hline & \multirow[b]{2}{*}{$c$} & gD & 8 & $93 \pm 19^{\mathrm{a}}$ & $20.7 \pm 5.5^{\mathrm{a}}$ & $25.6 \pm 6.5^{\mathrm{a}}$ & $41.5 \pm 9.2^{\mathrm{a}}$ & $10.0 \pm 5.5^{\mathrm{a}}$ & $13.1 \pm 10.2^{\mathrm{a}}$ & $16.9 \pm 9.6^{\mathrm{a}}$ & $0.86 \pm 0.35^{\mathrm{a}}$ \\
\hline & & gI & 6 & $82 \pm 13^{\mathrm{a}}$ & $14.0 \pm 3.5^{b}$ & $18.7 \pm 3.1^{\mathrm{b}}$ & $42.5 \pm 5.9^{\mathrm{a}}$ & $5.4 \pm 2.4^{\mathrm{b}}$ & $12.7 \pm 4.4^{\mathrm{a}}$ & $26.4 \pm 9.2^{\mathrm{b}}$ & $0.85 \pm 0.25^{\mathrm{a}}$ \\
\hline \multirow{6}{*}{ Q. petraea } & \multirow[b]{2}{*}{ A } & $\mathrm{gD}$ & 9 & $162 \pm 23^{a}$ & $40.5 \pm 3.8^{\mathrm{a}}$ & $43.3 \pm 3.6^{\mathrm{a}}$ & $59.8 \pm 3.4^{\mathrm{a}}$ & $17.5 \pm 5.8^{\mathrm{a}}$ & $14.2 \pm 6.2^{\mathrm{a}}$ & $13.9 \pm 6.6^{\mathrm{a}}$ & $0.67 \pm 0.32^{\mathrm{a}}$ \\
\hline & & gI & 11 & $149 \pm 18^{\mathrm{a}}$ & $36.8 \pm 4.7^{\mathrm{a}}$ & $41.3 \pm 5.1^{\mathrm{a}}$ & $62.9 \pm 6.9^{\mathrm{a}}$ & $15.6 \pm 6.2^{\mathrm{a}}$ & $22.4 \pm 9.8^{\mathrm{b}}$ & $23.3 \pm 10.8^{\mathrm{b}}$ & $0.71 \pm 0.30^{\mathrm{a}}$ \\
\hline & \multirow{2}{*}{$\mathrm{E}$} & gD & 5 & $127 \pm 34^{\mathrm{a}}$ & $34.5 \pm 7.7^{\mathrm{a}}$ & $39.6 \pm 7.7^{\mathrm{a}}$ & $53.3 \pm 6.6^{\mathrm{a}}$ & $22.7 \pm 11.7^{\mathrm{a}}$ & $23.0 \pm 11.2^{\mathrm{a}}$ & $15.3 \pm 7.0^{\mathrm{a}}$ & $0.61 \pm 0.39^{\mathrm{a}}$ \\
\hline & & gI & 13 & $127 \pm 31^{\mathrm{a}}$ & $35.6 \pm 8.2^{\mathrm{a}}$ & $39.7 \pm 8.6^{\mathrm{a}}$ & $58.6 \pm 6.8^{\mathrm{a}}$ & $19.8 \pm 11.0^{\mathrm{a}}$ & $19.5 \pm 10.7^{\mathrm{a}}$ & $25.3 \pm 13.0^{\mathrm{a}}$ & $0.49 \pm 0.37^{\mathrm{a}}$ \\
\hline & \multirow{2}{*}{$C$} & gD & 9 & $114 \pm 4^{\mathrm{a}}$ & $29.6 \pm 6.1^{\text {a }}$ & $31.9 \pm 6.4^{\mathrm{a}}$ & $43.2 \pm 2.7^{\mathrm{a}}$ & $10.7 \pm 5.1^{\mathrm{a}}$ & $9.2 \pm 4.6^{\mathrm{a}}$ & $9.8 \pm 3.5^{\mathrm{a}}$ & $0.79 \pm 0.33^{\mathrm{a}}$ \\
\hline & & gI & 11 & $103 \pm 15^{\mathrm{b}}$ & $25.6 \pm 5.0^{\mathrm{a}}$ & $29.7 \pm 5.2^{\mathrm{a}}$ & $47.0 \pm 7.2^{\mathrm{a}}$ & $11.6 \pm 3.8^{\mathrm{a}}$ & $14.6 \pm 6.3^{b}$ & $19.0 \pm 8.0^{\mathrm{b}}$ & $0.53 \pm 0.47^{\mathrm{a}}$ \\
\hline \multirow{4}{*}{ F. excelsior } & \multirow[b]{2}{*}{$\mathrm{A}$} & $\mathrm{gD}$ & 7 & $95 \pm 8^{\mathrm{a}}$ & $26.0 \pm 3.5^{\mathrm{a}}$ & $31.5 \pm 3.9^{\mathrm{a}}$ & $49.4 \pm 7.0^{\mathrm{a}}$ & $12.8 \pm 3.0^{\mathrm{a}}$ & $16.9 \pm 6.9^{\mathrm{a}}$ & $15.9 \pm 7.3^{\mathrm{a}}$ & $0.43 \pm 0.30^{\mathrm{a}}$ \\
\hline & & gI & 13 & $96 \pm 9^{\mathrm{a}}$ & $24.1 \pm 3.2^{\mathrm{a}}$ & $29.6 \pm 3.9^{\mathrm{a}}$ & $45.7 \pm 4.3^{\mathrm{a}}$ & $16.1 \pm 5.7^{\mathrm{a}}$ & $20.2 \pm 9.9^{b}$ & $20.8 \pm 11.3^{\mathrm{a}}$ & $0.33 \pm 0.40^{\mathrm{a}}$ \\
\hline & & gD & 11 & $102 \pm 14^{\mathrm{a}}$ & $27.3 \pm 4.6^{\mathrm{a}}$ & $33.1 \pm 4.6^{\mathrm{a}}$ & $51.0 \pm 4.8^{\mathrm{a}}$ & $14.6 \pm 4.3^{\mathrm{a}}$ & $22.5 \pm 4.8^{\mathrm{a}}$ & $22.6 \pm 6.4^{\mathrm{a}}$ & $0.52 \pm 0.30^{\mathrm{a}}$ \\
\hline & & gI & 8 & $100 \pm 11^{\mathrm{a}}$ & $26.5 \pm 5.4^{\mathrm{a}}$ & $32.0 \pm 5.8^{\mathrm{a}}$ & $52.5 \pm 3.3^{\mathrm{a}}$ & $14.8 \pm 4.9^{\mathrm{a}}$ & $20.8 \pm 6.2^{\mathrm{a}}$ & $32.4 \pm 8.8^{\mathrm{b}}$ & $0.74 \pm 0.39^{\mathrm{a}}$ \\
\hline
\end{tabular}


Dependence of growth resilience on tree and neighborhood characteristics

We investigated growth resilience $(R s)$ after the two major drought episodes, i.e. radial increment in the 10 years after the event relative to the 10 years before, in its dependence on

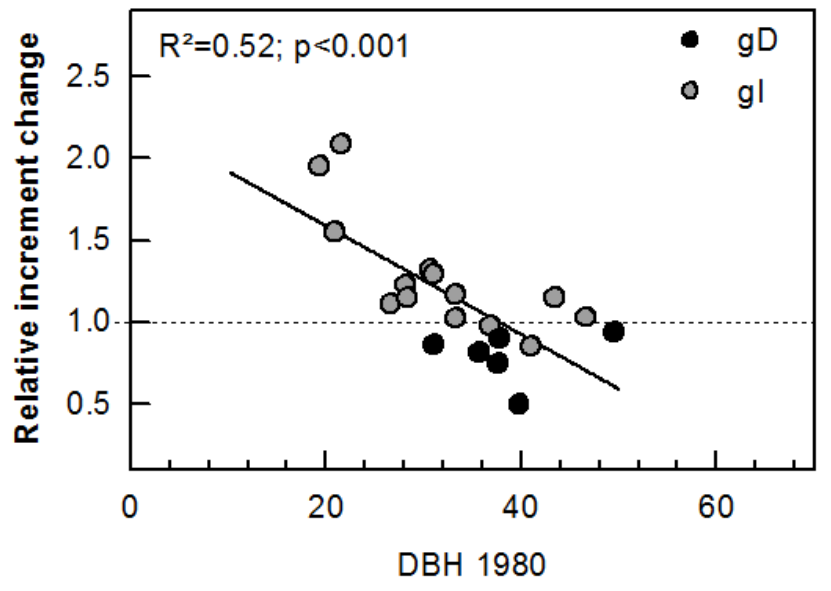

Figure 4.3. Change in mean basal area increment since 1980 relative to the BAI from 1951-1980 in dependence on $\mathrm{DBH}$ in 1980 for 20 beech trees of stand $\mathrm{C}$ (values $>1$ : growth increase, values $<1$ : decrease). The two populations gD and gI are marked by different symbols. important tree properties by regressing Rs on tree age, $\mathrm{DBH}$ and current growth rate (Table 4.3). While none of the three parameters influenced $R s$ in a consistent manner across all species and stands, $\mathrm{DBH}$ and radial growth rate - which were usually highly correlated - before a drought event had in general a higher explanatory power than tree age (tree height could not be reconstructed for the two drought events). In Fagus, resilience decreased with increasing $\mathrm{DBH}$ in all three stands in one of the two drought

events, and with increasing growth rate in two stands. In the other three species, only one stand each showed a significant relation of $R s$ to $\mathrm{DBH}$ and/or growth rate. As the Rs dependence was closest to DBH across the whole data set and this relation seemed to be the tighter, the larger the considered DBH range, we examined this relationship also in the pooled sample of all species.

Table 4.3. Regression models for individual species with the $\mathrm{R}^{2}$ and $\mathrm{p}$-values for the dependence of radial growth resilience on tree age, DBH or actual radial growth rate (GR) in the four tree species.

\begin{tabular}{|c|c|c|c|c|c|c|c|}
\hline \multirow{2}{*}{ Species } & \multirow{2}{*}{ Stand } & \multicolumn{3}{|c|}{ Drought event I } & \multicolumn{3}{|c|}{ Drought event II } \\
\hline & & Age & DBH 1974 & GR 65-74 & Age & DBH 1987 & GR 78-87 \\
\hline \multirow{3}{*}{ F. sylvatica } & A & $0.22 / 0.04$ & $0.02 / 0.52$ & $0.00 / 0.78$ & $0.15 / 0.10$ & $0.80 /<0.001$ & $0.53 /<0.001$ \\
\hline & B & $0.01 / 0.67$ & $0.09 / 0.19$ & $0.08 / 0.23$ & $0.03 / 0.50$ & $0.23 / 0.03$ & $0.19 / 0.05$ \\
\hline & $\mathrm{C}$ & $0.18 / 0.06$ & $0.44 / 0.001$ & $0.47 /<0.001$ & $0.02 / 0.55$ & $0.00 / 0.86$ & $0.13 / 0.12$ \\
\hline \multirow{3}{*}{$\begin{array}{l}\text { A. pseudo- } \\
\text { platanus }\end{array}$} & A & $0.05 / 0.40$ & $0.02 / 0.65$ & $0.09 / 0.27$ & $0.01 / 0.70$ & $0.01 / 0.68$ & $0.20 / 0.1$ \\
\hline & B & $0.00 / 0.95$ & $0.35 / 0.02$ & $0.61 /<0.001$ & $0.18 / 0.11$ & $0.01 / 0.66$ & $0.08 / 0.29$ \\
\hline & $\mathrm{C}$ & $0.03 / 0.55$ & $0.12 / 0.22$ & $0.09 / 0.28$ & $0.02 / 0.60$ & $0.21 / 0.12$ & $0.15 / 0.16$ \\
\hline \multirow{3}{*}{ Q. petraea } & A & $0.14 / 0.11$ & $0.23 / 0.03$ & $0.02 / 0.53$ & $0.10 / 0.17$ & $0.03 / 0.50$ & $0.01 / 0.62$ \\
\hline & B & $0.14 / 0.13$ & $0.09 / 0.24$ & $0.1 / 0.19$ & $0.03 / 0.48$ & $0.14 / 0.13$ & $0.09 / 0.12$ \\
\hline & $\mathrm{C}$ & $0.09 / 0.19$ & $0.19 / 0.06$ & $0.02 / 0.60$ & $0.07 / 0.26$ & $0.17 / 0.07$ & $0.07 / 0.25$ \\
\hline \multirow{2}{*}{ F. excelsior } & A & $0.00 / 0.77$ & $0.02 / 0.51$ & $0.00 / 0.91$ & $0.00 / 0.90$ & $0.06 / 0.30$ & $0.01 / 0.66$ \\
\hline & B & $0.00 / 0.80$ & $0.16 / 0.09$ & $0.27 / 0.02$ & $0.00 / 0.84$ & $0.02 / 0.61$ & $0.08 / 0.24$ \\
\hline
\end{tabular}


Indeed, when the data were pooled over all investigated species of a stand, significant negative relationships between $\mathrm{DBH}$ and $R$ s were detected for all three stands and both drought episodes (Fig. 4.4). The only exception was stand A during the 1975/76 drought episode where no significant relation appeared (Fig. 4.4: upper panel). The negative DBH effect on growth resilience was in many cases to a large extent contributed by Fagus, but the effect remained significant when this species was excluded. That the negative DBH resilience relationship does exist not only at the intraspecific but also at the community level in the mixed stands, is best demonstrated in stand C, where Fagus, Quercus and Acer represent different diameter classes.
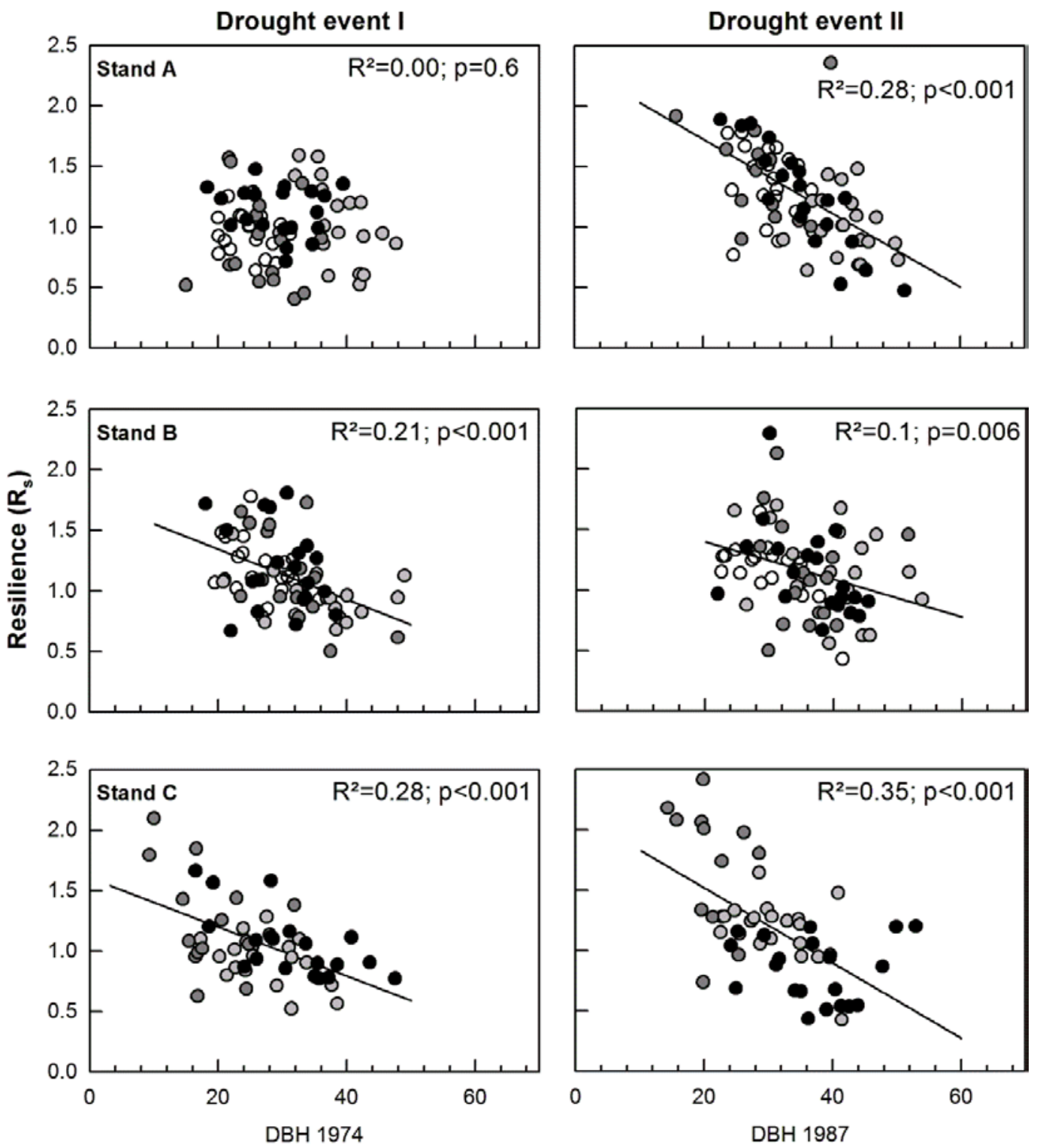

- F. sylvatica

- A. pseudoplatanus

○ Q. petraea

- F. excelsior

Figure 4.4. Dependence of growth resilience $(R s)$ on tree DBH in the three mixed stands A, B and C for the two drought events. The four species are pooled in the analyses. 
Table 4.4. Results of the model selection for the dependence of growth resilience on the target tree's DBH and its neighborhood characteristics based on Akaike's information criterion (AIC). Only cases where the base model did explain a reasonable amount of variance $\left(\mathrm{R}^{2}>0.15\right)$, were selected for model improvement. In case the basic model with DBH could not be improved by including the proportion of certain species in the neighborhood, no values are given. \%F. sylvatica: percentage of Fagus sylvatica in the neighborhood of a target tree, impr.: improved. *The added variable always had a negative impact on growth resilience.

\begin{tabular}{lccccccccc}
\hline \multicolumn{1}{c}{ Species } & Stand & $\begin{array}{c}\text { Drought } \\
\text { event }\end{array}$ & $\begin{array}{c}\text { AIC } \\
\text { basic } \\
\text { model }\end{array}$ & $\begin{array}{c}\text { AIC } \\
\text { impr. } \\
\text { model }\end{array}$ & $\begin{array}{c}\text { added } \\
\text { variable* }\end{array}$ & $\begin{array}{c}\text { adj. } \mathbf{R}^{2} \text { impr. } \\
\text { model }\end{array}$ & $\begin{array}{c}\text { p-value } \\
\text { impr. } \\
\text { model }\end{array}$ & $\begin{array}{c}\text { p value } \\
\text { DBH }\end{array}$ & $\begin{array}{c}\text { p-value } \\
\text { added } \\
\text { variable }\end{array}$ \\
\hline \multirow{2}{*}{ F. sylvatica } & A & II & -63.1 & - & - & - & - & - & - \\
& B & II & -41.5 & -46.4 & $\%$ F. sylvatica & 0.39 & 0.006 & 0.01 & 0.02 \\
\hline A. pseudo- & C & I & -60.6 & - & - & - & - & - & - \\
platanus & C & I & -35.5 & - & - & - & - & - & - \\
\hline & II & -16.2 & -21.1 & $\%$ F. sylvatica & 0.45 & 0.02 & 0.03 & 0.02 \\
Q. petraea & C & I & -47.2 & - & - & - & - & - & - \\
& I & II & -56.9 & - & - & - & - & - & - \\
\hline F. excelsior & B & I & -57.2 & - & - & - & - & - & - \\
\hline
\end{tabular}

The large-diameter Fagus trees had lowest Rs values and often showed a long-term growth decline, while the Quercus and Acer trees with intermediate or smallest diameters had intermediate and highest resiliences, respectively, and were not affected by a growth decline. In this stand, dominance patterns in terms of relative basal area increment shifted from F. sylvatica to A. pseudoplatanus after the 1988-1992 drought episode (Fig. 4.5).

The regression models built to explain variation in $R s$ across the species were not improved when including neighborhood diversity as expressed by Shannon's H'as an additional parameter. This suggests that heterospecific neighborhoods did not increase the resilience of radial growth to a drought event in these stands.

Adding the proportion of competing species in the neighborhood as explaining variable to the individual species models improved them only in two cases: the presence of Fagus decreased the resilience of Acer in stand C, and that of Fagus itself in stand B (Table 4.4). In this analysis, we included only cases in which the basic model had $\mathrm{R}^{2}$ value greater than
0.15 (corresponding to $\mathrm{p}$-values $<0.1)$.

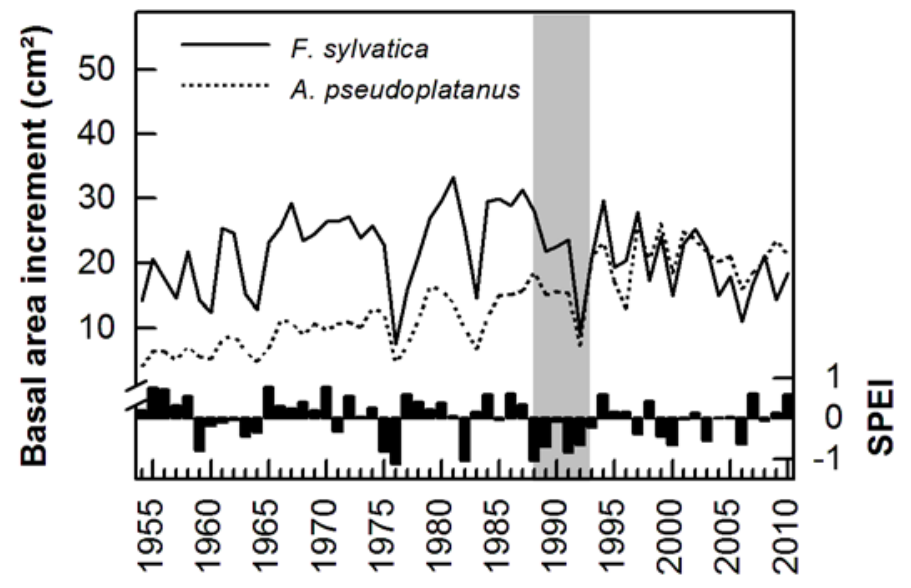

Figure 4.5. Mean basal area increment (BAI) of F. sylvatica and A. pseudoplatanus in the period 1954-2010 in stand C. The total populations were investigated, i.e. 20 or 14 trees per species. The standardized precipitationevapotranspiration index (SPEI) is also depicted. 


\section{Discussion}

Drought effects on the competitive hierarchy of the species

Our growth analysis in the context of the two extended drought episodes demonstrates that the co-occurring tree species are responding differently to these severe stress events. The two ring-porous species Quercus petraea and Fraxinus excelsior are hardly affected by the 5-yrlong period of relatively dry summers from 1988 to 1992, while the two diffuse-porous species Acer pseudoplatanus and in particular Fagus sylvatica suffered considerably. Fagus showed in the 1988-1992 drought episode an even greater growth depression than in the extreme pan-European drought summer 1976. These findings match earlier drought tolerance assessments of the four species which considered the two ring-porous species to be highly drought tolerant, while considerable drought sensitivity was assigned to Fagus (Köcher et al. 2009; Scherrer et al., 2011). Increased summer temperatures could also play a role as a cause of the recent growth decline in F. sylvatica (Jump et al., 2006; Zimmermann et al., 2015).

Our data suggest that shifts in the species ratio of basal area increment in the mixed stands are triggered by extreme drought events as the 1988-1992 episode, rather than being a result of continuous decade-long competitive interactions. This is pointing to a threshold effect in the more sensitive species instead of a reaction to progressive deterioration of growing conditions due to the ongoing warming and drying of the climate. The most impressive crossing of growth trends among two co-occurring species was observed for Acer and Fagus in the driest stand C, where the largest beech trees showed declining growth after the 1988-1992 event, while the Acer trees markedly increased radial increment, apparently taking advantage of the decreasing vigor of the dominant beech trees. In fact, the Acer trees increased their BAI from only half the mean beech increment before 1980 to equal or higher rates than beech after the 1988-1992 episode (see Fig. 4.6), despite similar tree ages of the species. Since the investigated Fagus and Acer trees in most cases were not direct neighbors, the diverging growth trends mostly do not seem to result from direct competitive interactions but rather reflect specific responses of the investigated tree populations to a changing environment. A similar shift in growth trends triggered by the severe 1976 drought was observed in a Fagus sylvatica/Quercus petraea mixed stand in southwest England, where oak profited from the apparent drought-induced weakness of beech (Cavin et al. 2013). In our mixed stands, we observed no increment boost of Quercus after a Fagus growth decline. Rather, the BAI of the Q. petraea trees remained constant and approached that of the F. sylvatica trees at the end of the investigation period (data not shown). We speculate that this may partly be a consequence 
of the higher DBH and age of the Quercus trees compared to the Acer trees, which may have been more responsive.

Next to Acer, Fraxinus also seems to have profited from a growth decline in Fagus: in stand A and B, where part of the beech population suffered increment decreases from 1992 onwards, various Fraxinus trees increased growth subsequently. In contrast to Acer, however, the apparent shift in growth trends in stand A between Fagus and Fraxinus occurred only in part of the studied trees and the relationship to the Fagus growth decline is not clear in our dataset.

An interesting phenomenon is that the Acer trees showed reduced growth resilience after drought in neighborhoods with higher presence of Fagus trees. This seems to contradict the conclusion that Acer profited from the growth decline of Fagus by higher basal area increment. A declining BAI in large Fagus trees is likely associated with a reduction in crown area and thus additional canopy space for competitors. On the other hand, Fagus is known to be capable of rapid canopy expansion by lateral branch growth (Pretzsch and Schütze, 2005; Schröter et al., 2012). We speculate that smaller Fagus trees that were less affected by drought, responded with vigorous branch growth in the recovery period after the 1988-1992 drought, thereby suppressing heterospecific competitors, even though large Fagus trees underwent long-term growth decline. To fully disentangle the effects of species identity and neighbor size on the growth resilience of the target trees, a complete neighborhood analysis, where the size of the neighbors can be reconstructed in the same way as was done for the target trees, would be necessary. If smaller trees in the neighborhood are stronger competitors than large ones after severe droughts, this would shed new light on the widespread assumption that larger trees are generally superior competitors because they are monopolizing access to light.

The given explanation of the stress response of Fagus is consistent with the observation that the growth resilience was reduced by a higher Fagus abundance in the neighborhood also in the beech target trees themselves. In other words, the growth resilience in Fagus was higher in heterospecific than in monospecific neighborhood, which is in line with the findings of Pretzsch et al. (2012) in a Fagus-Quercus mixed stand. In both cases, Fagus was more resilient to drought in mixture, while the other species (Quercus petraea; in our study also Fraxinus) were neither negatively affected nor profited from the Fagus neighborhood. Thus, the apparent facilitation was one-sided.

Mölder et al. (2014) found Fagus to be more drought resistant in a 5-species mixed forest in heterospecific than monospecific neighborhood, but this effect appeared only on clay-rich 
soil. This is also the case in our study, where Fagus showed a clear benefit from heterospecific neighbors only in stand B which grew on clay-richer soil than the other two stands. This effect may be related to the low hydraulic conductivity of clay. In general, the neighbor species effect was rather weak compared to the effect of tree size and overlain by the latter; it was only visible in the models in combination with tree size (Table 4.5).

The diversity of a target tree's neighborhood, expressed by Shannon's H', was not a significant factor increasing growth resilience. Thus, as hypothesized, species identity in the neighborhood mattered but not diversity. In this context, it is important to separate between positive effects of more diverse forests on stand-level drought resistance, as observed e.g. by Grossiord et al. (2014) and Pretzsch et al. (2012) in certain temperate forest stands, and the growth resilience after drought of single target trees in mixture. At the stand level, possible facilitative interactions may be effective that can increase the growth performance of more diverse stands during drought via processes such as hydraulic lift or improved water storage of modified organic layers (Augusto et al., 2002; Richards et al., 2010). This will be less important for single trees which primarily can profit from a neighbor with a water-saving strategy or when largely different soil water reserves are explored.

This suggests that the drought sensitivity of a mixed forest is influenced by tree species identity (and diversity) at the tree and stand level in different ways. At the tree level, certain individuals, notably large trees of water-spending species, may profit in their growth rates and growth resilience after drought from neighbors with more conservative water use, as seen in Fagus when growing close to Quercus or Fraxinus. At the stand level, a more diverse stand has a greater likelihood that sensitive species such as Fagus and more tolerant species as Acer or Quercus grow in direct neighborhood to each other and develop opposing drought response patterns, whereby the stand level growth response is buffered against extreme events. Structural and functional stability at the stand level is then achieved through higher compositional dynamics.

\section{Drought effects on tree population dynamics}

With the cluster analysis, we were able to identify tree groups within the populations that differed with respect to long-term growth trends and drought response. DBH (together with current growth rate) was identified as an important determining factor of a growth decline across all four species, suggesting that tree size is an important determinant of drought sensitivity in the Central European broad-leaved tree flora. As expected, diameter is interacting with the physiological and morphological constitution of the species, as the 
diameter dependence was closer in the more drought-sensitive diffuse-porous species Fagus and Acer than in the less sensitive ring-porers Quercus and Fraxinus.

In the species without overall recent growth decline (Acer, Quercus, Fraxinus), the growth curves of the gI and gD groups started to diverge in the three stands at different points of time which suggests that the increase in the gI increment curve is caused by a set of local factors. One likely cause of better growth of the gI trees is decreasing vigor of neighboring large Fagus trees; this may apply not only to Acer and Fraxinus, but also to Quercus and even to the gI group of Fagus itself.

Another possible cause is small-scale differences in soil water availability in the stands which increasingly may have influenced the trees' vigor in the course of climate warming in recent decades. It could be that the gI trees grow on somewhat more favorable soil profiles than the gD trees but the site difference became decisive only with increased climatic aridity in recent time.

Tree size differences and associated better light access of thicker and taller trees are not a likely explanation for the better growth of the gI trees. In fact, thicker trees in general suffered more from the extreme droughts in our study than smaller individuals. This is in accordance with various observations in other temperate and tropical forests showing that large dominant trees with high growth rates typically experience the largest growth reductions during drought (e.g. Mueller et al., 2005; Moser et al., 2013; Rodriguez-Caton et al., 2015). A likely explanation is that tall trees have a more exposed crown and thus face a higher evaporative demand than smaller trees that are embedded in the canopy. Any decrease in radial growth is associated with reduced formation of new conducting xylem elements in the stem which further deteriorates the water supply to the crown. This hydraulic consequence of a droughtinduced growth decline was shown by Zimmermann et al. (unpublished) for the larger Fagus trees of this study in the period since 1980. If trees of drought-sensitive species with smaller $\mathrm{DBH}$ are generally favored by extreme drought events, the assumption that larger trees are generally superior competitors, may not be valid for our stands. Our data rather suggest that extreme drought events increase the turnover of individuals within the population by promoting the growth of inferior, less exposed individuals at the cost of trees that dominated in the past. This may have consequences for forestry practice, when intensive thinning results in increased diameters of the remaining trees which may be more susceptible to drought (Amato et al., 2013). 


\section{Conclusions}

While tree physiologists and forest ecologists are recently mainly concerned with climate warming-related tree death and its causes, sub-letal drought is causing decline in vigor and triggering a multitude of adaptive responses at the cellular, whole-tree and stand level, that are not sufficiently understood. However, these responses decide what degree of warming and drying tree species are able to tolerate and how the species composition of natural mixed forests will change in future due to differential species responses. Our results highlight the paramount importance of extreme drought events, in particular extended drought periods spanning several summers, for tree vigor and productivity. Convincing evidence was presented that Fagus sylvatica is actually losing competitive strength in mixed stands in the center of its distribution range in Central Europe in places where annual precipitation is lower than $\sim 600 \mathrm{~mm}$ (or the precipitation in June-August is below $\sim 190 \mathrm{~mm}$; Scharnweber et al., 2011; Zimmermann et al., 2015). This has consequences for natural forest dynamics in that A. pseudoplatanus, Quercus petraea, Fraxinus excelsior, Carpinus betulus, Tilia cordata and other more drought-tolerant species may at least partly replace beech in these stands in the long run. It might be decisive, whether smaller F. sylvatica individuals will be capable of successfully replacing the larger beeches with reduced vigor, or whether they quickly suffer the same fate of growth decline after reaching a critical diameter. Foresters have to take the drought sensitivity of Fagus into account when planning production forests in regions where summer precipitation (June - August) is already below $190 \mathrm{~mm}$ or will meet this threshold with future climate drying. Species-richer and structurally more heterogeneous stands may represent one option to decrease the drought and heat sensitivity of production forests.

\section{Acknowledgements}

This study was conducted in the framework of Graduiertenkolleg 1086 funded by Deutsche Forschungsgemeinschaft (DFG). The financial support granted is gratefully acknowledged. We thank the DBU (Deutsche Bundesstiftung Umwelt) and the administration of the Biosphere Reserve Karstlandschaft-Südharz for allowing to conduct tree coring in their stands. We thank the DWD (Deutscher Wetterdienst, Offenbach) for supplying climate data. 


\section{References}

Allen CD, Macalady AK, Chenchouni H, Bachelet D, McDowell N, Vennetier M Kitzberger T, Rigling A, Breshears DD, Hogg EH, Gonzalez P,Fensham R, Zhang Z, Castro J, Demidova N, Lim JH, Allard G, Running SW, Semerci A, Cobb N. 2010. A global overview of drought and heat-induced tree mortality reveals emerging climate change risks for forests. Forest Ecology and Management 259: 660-684.

Amato AW, Bradford JB, Fraver S, Palik BJ. 2013. Effects of thinning on drought vulnerability and climate response in north temperate forest ecosystems. Ecological Applications 23: 1735-1742.

Augusto L, Ranger J, Binkley D, Rothe A. 2002. Impact of several common tree species of European temperate forests on soil fertility. Annals of Forest Science 59: 233-253.

Baillie MG, Pilcher, JR. 1973. A simple cross-dating program for tree-ring research. TreeRing Bulletin 33: 7-14.

Bréda N, Huc R, Granier A, Dreyer E. 2006. Temperate forest trees and stands under severe drought: a review of ecophysiological responses, adaptation processes and long-term consequences. Annals of Forest Science 63: 625-644.

Bolte A, Czajkowski T, Kompa T. 2007. The north-eastern distribution range of European beech - a review. Forestry 80: 413-429.

Canham CD, Papaik MJ, Uriarte M, McWilliams WH, Jenkins JC, Twery MJ. 2006. Neighborhood analyses of canopy tree competition along environmental gradients in new England forests. Ecological Applications 16: 540-554.

Cavin L, Mountford PE, Peterken GF, Jump AS. 2013. Extreme drought alters competitive dominance within and between tree species in a mixed forest stand. Functional Ecology 27: 1424-1435.

Eckstein D, Bauch J. 1969. Beitrag zur Rationalisierung eines dendrochronologischen Verfahrens und zur Analyse seiner Aussagesicherheit. Forstwissenschaftliches Centralblatt 88: 230-250.

Ellenberg H, Leuschner C. 2010. Vegetation Mitteleuropas mit den Alpen in ökologischer, dynamischer und historischer Sicht. 6th ed. Stuttgart: Ulmer.

Grossiord C, Granier A, Ratcliffe S, Bouriaud O, Bruelheide H, Che'cko E, Forrester DI, Dawud SM, Finér L, Pollastrini M, Scherer-Lorenzen M, Valladares F, Bonal D, Gessler A. 2014. Tree diversity does not always improve resistance of forest ecosystems to drought. PNAS 111:14812-14815.

Hammer O, Harper DAT, Ryan PD. 2001. PAST: Paleontological Statistics software package for education and data anlysis. Palaeontologia Electronica 4: 9-17. 
Jump AS, Hunt JM, Penuelas J. 2006. Rapid climate change-related growth decline at the southern range edge of Fagus sylvatica. Global Change Biology 12: 2163-2174.

Köcher P, Gebauer T, Horna V, Leuschner C. 2009. Leaf water status and stem xylem flux in relation to soil drought in five temperate broad-leaved tree species with contrasting water use strategies. Annals of Forest Science 66: 101.

Köcher P, Horna V, Leuschner C. 2013. Stem water storage in five coexisting temperate broad-leaved tree species: significance, temporal dynamics and dependence on tree functional traits. Tree Physiology 33: 817-832.

Lang C, Seven J, Polle A. 2011. Host preferences and differential contributions of deciduous tree species shape mycorrhizal species richness in a mixed Central European forest. Mycorrhiza 21: 297-308.

Lloret F, Keeling EG, Sala A. 2011. Components of tree resilience: effects of successive lowgrowth episodes in old ponderosa pine forests. Oikos 120: 1909-1920.

Mölder I, Leuschner C. 2014. European beech grows better and is less drought sensitive in mixed than in pure stands: tree neighbourhood effects on radial increment. Trees 28: 777-792.

Moser G, Schuldt B, Hertel D, Horna V, Coners H, Barus H, Leuschner C. 2014. Replicated throughfall exclusion experiment in an Indonesian prehumid rainforest: wood production, litter fall and fine root growth under simulated drought. Global Change Biology 20: 1481-1497.

Mueller RC. Scudder CM, Porter ME, Trotter III RT, Gehring CA, Whitham TG. 2005. Differential tree mortality in response to severe drought: evidence for long-term vegetation shifts. Journal of Ecology 93: 1085-1093.

Peuke AD, Gessler A, Rennenberg H. 2006. The effect of drought on C and N stable isotopes in different fractions of leaves, stems and roots of sensitive and tolerant beech ecotypes. Plant, Cell and Environment 29: 823-835.

Pretzsch H, Schütze G. 2005. Cron allometry and growing space efficiency of Norway spruce (Picea abies [L.] Karst.) and European beech (Fagus sylvatica L.) in pure and mixed stands. Plant Biology 7: 628-639.

Pretzsch H, Schütze G. 2009. Transgressive overyielding in mixed compared with pure stands of Norway spruce and European beech in Central Europe: evidence on stand level and explanation on individual tree level. European Journal of Forest Research 128: 183204.

Pretzsch H, Schütze G, Uhl E. 2012. Resistance of European tree pecies to drought stress in mixed versus pure forests: evidence of stress release by inter-specific facilitation. Plant Biology 15: 483-495. 
R Development Core Team. 2008. R: A language and environment for statistical computing. R Foundation for Statistical Computing, Vienna, Austria. ISBN 3-900051-07-0, URL http://www.R-project.org.

Richards AE, Forrester DI, Bauhus J, Scherer- Lorenzen M. 2010. The influence of mixed tree plantations on the nutrition of individual species: a review. Tree Physiology 30: 1192-1208.

Rodríguez-Caton M, Villalba R, Srur AM, Luckman B. 2015. Long-term trends in radial growth associated with Nothofagus pumilio forest decline in Patagonia: Integrating local- into regional-scale patterns. Forest Ecology and Management 339: 44-56.

Rose L, Leuschner C, Köckemann B, Buschmann H. 2009. Are marginal beech (Fagus sylvatica L.) provenances a source for drought tolerant ecotypes? European Journal of Forest Research 128: 335-343.

Scharnweber T, Manthey M, Criegee C, Bauwe A, Schröder A, Wilmking M. 2011. Drought matters - Declining precipitation influences growth of Fagus sylvatica L. and Quercus robur L. in north-eastern Germany. Forest Ecology and Management 262: 947-961.

Scherrer D, Bader KFB, Körner C. 2011. Drought-sensitivity ranking of deciduous tree species based on thermal imaging of forest canopies. Agriculture and Forest Meteorology 151: 1632-1640.

Schröter M, Härdtle W, Oheimb G. 2012. Crown plasticity and neighborhood interactions of European beech (Fagus sylvatica L.) in an old-growth forest. European Journal of Forest Research 131: 787-798.

Sohn JA, Gebhard T, Ammer C. Bauhus J. Häberle KH, Matyssek R, Grams TEE. 2013. Mitigation of drought by thinning: Short-term and long-term effects on growth and physiological performance of Norway spruce (Picea abies). Forest Ecology and Management 308: 188-197.

Spellerberg IF, Fedor PJ. 2003. A tribute to Claude Shannon (1916-2001) and a plea for more rigorous use of species richness, species diversity and the 'Shannon-Wiener' Index. Global Ecology and Biogeography 12:177-179.

Thornthwaite CW. 1948. An approach toward a rational classification of climate. Geographical Review 38: 55-94.

Valladares F, Sánchez-Gómez D. 2006. Ecophysiological traits associated with drought in Mediterranean tree seedlings: Individual responses versus interspecific trends in eleven species. Plant Biology 8: 688-697.

Vincente-Serrano SM, Begueria S, Lopez-Moreno JI. 2009. A multiscalar drought index sensitive to global warming: The standardized precipitation evapotranspiration index. Journal of Climate 23: 1696-1718. 
Ward JH. 1963. Hierarchical grouping to optimize an objective function. Journal of American Statistical Association 58: 236-244.

Yachi S, Loreau M. 1999. Biodiversity and ecosystem productivity in a fluctuating environment: the insurance hypothesis. PNAS 96: 1463-1468.

Zimmermann J, Hauck M, Dulamsuren C, Leuschner C. 2015. Climate warming-related growth decline affects Fagus sylvatica, but not other broad-leaved tree species in Central European mixed forests. Ecosystems 18: 560-572. 

Chapter 5

\section{Synthesis}



The impact of drought and climate warming on Central European mixed forests

The growth of tree species in Central European forests is strongly influenced by climate conditions of the spring and summer months. This has not only been shown in the present dendrochronological study (chapter 2), but in many other studies as well (e.g. Dittmar et al. 2003; Karpavicius and Vitas 2006; Fonti and García-González 2008). It can thus be assumed that the predicted changes in climate - increasing temperatures and regional decreasing summer precipitation combined with long-lasting drought periods (IPCC 2013) - will have considerable impact on forest ecosystems. To determine how individual species will be affected and what effects can be expected on the ecosystem scale is a complex and ambitious task.

Fagus sylvatica was the only of the five investigated species that showed growth decline since about 1980 in the first study (chapter 2). This decline was closely related to increasing temperatures, but only distinct at the driest of the three investigated stands. F. sylvatica also showed the strongest decrease in increment during drought events and the frequency of corresponding growth depressions (negative pointer years) increased during the end of the investigated period only in this species.

Regarding its anatomy F. sylvatica showed a remarkable plasticity of its stem xylem (chapter 3). This plasticity to interannual, as well as long time changes in climatic conditions was expressed by smaller vessels, yet a higher vessel density under dry conditions. This allowed F. sylvatica to increase its potential conductivity $\left(K_{\mathrm{p}}\right)$ with increasing age/size and develop a water transport system less susceptible to drought induced cavitation at the same time. However, the other investigated species all increased their $K_{\mathrm{p}}$ through larger vessels with increasing age/size, what may be an indicator that $F$. sylvatica has to deviate from the usual development of the xylems anatomy to be able to persist under drought conditions. In addition, despite the adaptions, $K_{\mathrm{ann}}$ - the cumulative hydraulic conductivity, which a tree is producing annually in the course of radial growth - decreased together with tree-ring width, leading to a constant loss of conductivity along with the observed growth reductions.

The third study (chapter 4) revealed that the intensity of growth reductions in the investigated tree species after drought events as well as the observed growth decline in F. sylvatica at stand $\mathrm{C}$ is - amongst other things - dependent on the diameter at breast height (DBH) of a tree individual. As a result a shift in growth dominance patterns was visible; after drought events larger trees showed a decrease and smaller trees an increase in basal area increment (BAI) that surpassed that of the once dominant trees eventually. While visible in most species, 
this pattern was clearest in F. sylvatica and enabled small trees at stand C to even increase their BAI since 1980, contrary to the general trend.

As this study shows, climate warming-related growth decline in F. sylvatica is not restricted to its southern distribution range limit (Jump et al. 2006; Piovesan et al. 2008), but occurs also in the center of it. Corresponding growth decline in the center of $F$. sylvaticas distribution range was also observed by Scharnweber et al. (2011) and Knutzen et al. (unpublished). In accordance to the present study, growth decline occurred at stands with summer precipitation lower than $\sim 200 \mathrm{~mm}$ (depending on soil characteristics) or annual precipitation $<600 \mathrm{~mm}$. Equally important as precipitation thresholds are the role of increasing temperatures on growth of F. sylvatica, which are not very well researched. Growth decline could be caused by indirect effects like the triggering of masting through high temperatures (Piovesan and Adams 2001, Drobyshev et al. 2010, Müller-Haubold et al. 2013) and increased fine root production and turnover (Leuschner et al. 2001; Meier and Leuschner 2008; Mainero and Kazda 2006; Hertel et al. 2013), both causing reduced stem increment. Growth decline could also be caused by more direct effects like a higher atmospheric saturation deficit. In this context, the role of soil-water independent control of growth by air humidity could be an important factor (Köcher et al. 2012) that needs further investigation.

Studies of Müller-Haubold (2014) over a period of three years along the same precipitation gradient that was investigated by Knutzen et al. (unpublished) discovered that total aboveground biomass production was mostly unaffected along the gradient. While wood and - to a lesser extent - leaf biomass did decrease with decreasing precipitation, fruit biomass increased accordingly. Reductions in stem increment were linked to increased fruit biomass production, what would be a further explanation for the increase in the frequency of negative pointer years in F. sylvatica, as the frequency of masting events in this species also increased recently (Hilton and Packham 2003; Schmidt 2006; Övergaard et al. 2007). In addition, fine root production also increased with decreasing precipitation, making stands of $F$. sylvatica at the dry end of the gradient not at all less productive.

Contrary to the present studies, not only dominant, but all trees with $\mathrm{DBH}>15 \mathrm{~cm}$ and even half the trees with DBH of 7-15 cm have been sampled in the studies of Müller-Haubold. As seen in Chapter 4, BAI of small trees seem to be less effected by drought, so that even at the driest stand trees with diameters $<30 \mathrm{~cm}$ were able to increase their BAI in the second part of the investigated period (1981-2010), despite increasing summer drought intensity. Taking into account that mean DBH at the drier stands in the study of Müller-Haubold were lower than 30 cm, it may well be possible that these stands are less affected by dry conditions. Pretzsch et al. 
(2014) showed that total stand volume growth of F. sylvatica increased in the period 19612010 compared to 1870-1960 across a wide range of 22 stands with annual precipitation ranging from 605 to $1,369 \mathrm{~mm}$. While this study compares entirely different periods and stands with much higher precipitation amounts, it is a further indicator that impacts of drought and climate warming on dominant trees might differ from the impact at the whole stand level, at which negative effects can be compensated by less affected subdominant trees.

The reduction in the conductivity of the stem xylem that comes along with decreasing BAI (chapter 3) is a component of the forest decline concepts discussed by Manion (2003). One theory regarding the death of large dominant trees in the context of the forest decline concepts is that different species or different individuals of a species have either competitive dominant or stress-tolerant dominant tendencies. Competitive dominant trees maintain their dominance by building a large crown that needs a high-volume water transport system. Yet, to maintain this high-volume transport system the tree needs to produce corresponding large tree-rings widths each year. Thus, reductions in tree-ring width related to changes in climate lead to restrictions in the water transport system - as has been observed on the basis of decreasing $K_{\mathrm{ann}}$ in chapter 3 - that limit the trees capabilities to maintain and recover the large crown, and in response lead to further reductions in increment and eventually to growth decline as observed in F. sylvatica.

One possible solution to maintain a high-volume water transport system despite reduced conductive area would be an increase in vessel size. Yet, while all other investigated species showed an increase in their hydraulic diameter $\left(D_{\mathrm{h}}\right)$ with increasing size, $F$. sylvatica did not. This increase in $D_{\mathrm{h}}$ with increasing age/size reflects the importance for a tree to be able to transport higher amounts of water to an increasing crown. Against this trend, decreasing water availability typically causes the formation of smaller xylem vessels and a higher vessel density (Carlquist 1977; Lens et al. 2004; Sterck et al. 2008; Fonti et al. 2013; Chenlemuge et al. 2014), to achieve a higher resistance to drought-induced xylem embolism (Fonti et al. 2013). That $F$. sylvatica most of all species showed a high plasticity in year to year variation of vessel size and density that were highly correlated with tree-ring width and controlled by the same climatic parameters, is a strong indicator that the missing increase in $D_{\mathrm{h}}$ is caused by the current changes in climate. This is supported by the fact that F. sylvatica did increase its vessel density to increase its potential conductivity $\left(K_{\mathrm{p}}\right)$ over the investigated period. Yet, a higher vessel density is way more limited to increase conductivity in a given area than an increase in vessels size would be, especially if the already very high vessel density of F. sylvatica (by far the highest of the investigated species) is taken into account. 
Considering the results of chapter 4 and the theories of Manion (2003), the observed effect of reduced $K_{\text {ann }}$ should also primarily apply to large trees. Unfortunately the sample size in the second study is rather low compared to the other two studies, making a more precise analysis, if and how the reduction in $K_{\mathrm{ann}}$ is dependent on tree size impossible.

One of the pressing questions regarding possible shifts in the species composition of Central European mixed forests in the course of climate warming is, if succeeding trees of $F$. sylvatica will be able to adapt to changes in climate that lead to an appropriate development of the wholes trees structure and if it is at the same time still able to achieve a dominant position in the long run through its high shade tolerance and plasticity.

\section{Predicting the future development of Central European mixed forest stands}

The results of the present studies mirror why predicting the development of forest ecosystems under a changing climate is so difficult, as the number of factors that influence a trees response to drought are numerous, and their expression are not only species specific but do also depend on the status and composition of an ecosystem and the position of an individual in this system. Furthermore, studies that investigated only one compartment of the whole tree might not reflect the actual processes happening at the whole tree scale and predictions based on corresponding results are likely to be inaccurate. As mentioned above, reductions in increment represent not necessarily reduced productivity (Müller-Haubold 2014). Also, different tree species may react to drought at different compartments of the plant. Lübbe et al. (unpublished) showed that F. sylvatica reacts to drought with strong modifications of the xylem but shows no reaction at the leaf level. In contrast, F. excelsior reacts with strong modification at the leaf level, but only minor modifications of the xylem are made. Based on the investigated part of the plant, this could lead to opposed assumptions about a tree species sensitivity to drought, while it only reflects the species strategy to react to drought.

Nevertheless, the results of the present studies suggest that $F$. sylvatica will lose some of its competitive strength in the course of climate warming, as the large, dominant trees of this species show a loss of vigor (growth decline paired with decreasing $K_{\mathrm{ann}}$ ) not only at the driest stand. However, less affected smaller trees of F. sylvatica might still be the strongest competitors in the investigated forest stands. Not only were they able to increase their growthrates despite a warmer and drier climate, but higher proportion of F. sylvatica in the neighborhood led also to reduced resilience of the target trees in some cases (chapter 4). It is likely that the species high shade tolerance and ability of canopy space filling by lateral 
branch growth (Pretzsch and Schütze 2005; Schröter et al. 2012) enables it to make the most use of gaps emerging from crown reductions of those trees that show a decline in growth.

An important factor for the future development of $F$. sylvatica will be, if those succeeding trees expand their crown to a size that they are affected in the same way as the currently dominant trees, or if the species is able to adapt its growth according to the changes in climate. As a closed canopy that completely shades the underlying stand is an important part of F. sylvaticas strategy, it can be assumed that succeeding trees will expand their crown in the same way as their predecessors, or that emerging gaps will be taken over by other species. In the former case there might be a point at which the dominant layer deceases quicker than succeeding trees are able to fill existing gaps and again other species will take over the emerging space. In this context the increased frequency of masting events in F. sylvatica could be a mechanism to fill emerging gaps by occupying as much space as possible through descendants, which suppress other species. To closer examine were the limits of F. sylvatica are, more importantly as a general precipitation threshold for the species would be the investigation of a size related precipitation threshold, to evaluate to which extend different stand formations are affected by drought and at which point a stand might not be able to regenerate itself. A possible solution from the standpoint of forestry could be, to shorten the rotation periods of F. sylvatica and harvest trees before they reach a critical size. Yet it has to be inquired if such methods would still allow for the natural regeneration of forest stands. Increased thinning in contrast, may in the long run lead to tree individuals more susceptible to drought, as the remaining individuals increase in size (Amato et al. 2013). In addition regeneration of the stand could be limited, because of missing successors.

Irrespective of the adaption processes in F. sylvatica, existing gaps will at least partially be captured by other species, as already observed at stand C, where A. pseudoplatanus benefited from the growth decline in F. sylvatica and showed a rapid increase in its growth-rates (chapter 4). Interestingly, A. pseudoplatanus is the species that has been found more or less equally drought sensitive as F. sylvatica, depending on the study (Köcher et al. 2009; Scherrer et al. 2011). In the context of forest decline concepts (Mainon 2003), one could assume that these two species represent competitive dominant species that build a large crown and quickly fill existing gaps, but are susceptible to drought. In contrast, Q. petraea would represent a stress-tolerant dominant species that does not react in the same way to opening gaps, but possesses a higher drought resistance. The high drought resistance of Q.petraea in comparison to F. sylvatica has been shown in many studies (e. g. Backes and Leuschner 2000; Leuschner et al. 2001; Scherrer et al. 2011; Mette et al. 2013). 
Through which species $F$. sylvatica is replaced if necessary is determined by various criteria and predictions based on the present studies are likely to be incomplete. A. pseudoplatanus might be the species that benefits the most at the moment, as it is able to quickly grow into open space. However, in the long run this species might share the fate of F. sylvatica for similar reasons (a large crown that cannot be maintained during drought episodes). While A. platanoides was found in this study to possess the higher drought tolerance of the two Acer species, it seems to be too weak as a competitor to actually surpass the other species. This is reflected in the rather low abundance in the stands and the low increment. The low competitive strength of this species is attributed to its reduced height increment and high light demand (Roloff and Schütt 2006), but it may be able to conquer emerging larger gaps, thanks to its high seed production.

The two ring-porous species $Q$. petraea and F. excelsior were found to be the least sensitive to drought of the investigated species, what matches the results of other studies (Köcher et al. 2009; Scherrer et al. 2011). As stated above, Q. petraea has often been compared to F. sylvatica and always found to be the less drought sensitive species. Härdtle et al. (2013) showed that $Q$. petraea is remarkable insensitive to drought, even on relative shallow Regosols. Accordingly, it has been observed that F. sylvatica loses its competitive superiority over Q. petraea with decreasing precipitation (Bonn 1998) or after severe drought events (Cavin et al. 2013). Thus, it seems likely that the competitive strength of Q. petraea will increase with the predicted changes in climate and that this species will be able to get an advantage over others at drier stands in the course of climate warming.

While less well researched, F. excelsior shows insensitivity to drought similar to that of Q. petraea in the present as well as other studies (Köcher et al. 2009; Scherrer et al. 2011). Yet, the future existence of this species is threatened by an emerging fungal disease that is quickly spreading and lethally affects this species leading to diebacks all across Europe (Pautasso et al. 2013).

The case of F.excelsior shows that the conditions for a species can quickly change in an unpredictable manner. Such changes can also be expected in the course of climate warming, making it mostly unpredictable how species might finally be affected through the changes in climate, as for example invading species and the rapid reproduction of insects and other pests may threaten whole species in unforeseeable ways. To accommodate such unpredictable events, the establishment and preservation of species rich forest stands should be payed attention. In reference to the insurance hypothesis of biodiversity (Yachi and Loreau 1998), structure rich, mixed forest stands seem to be a suitable approach for healthy, self-regulating 
forest stands that are unlikely to experience a complete breakdown through disturbances that inevitable will occur in the course of climate warming. 


\section{References}

Amato AW, Bradford JB, Fraver S, Palik BJ. 2013. Effects of thinning on drought vulnerability and climate response in north temperate forest ecosystems. Ecological Applications 23: 1735-1742.

Backes K, Leuschner C. 2000. Leaf water relations of competitive Fagus sylvatica and Quercus petraea trees during 4 years differing in soil drought. Canadian Journal of Forest Research 30: 335-346.

Bonn S. 1998. Dendroökologische Untersuchung der Konkurrenzdynamik in Buchen/EichenMischbestanden und $\mathrm{zu}$ erwartende Modifikationen durch Klimaänderungen. Forstwissenschaftliche Beitrage Tharandt/Contributions to Forest Sciences No. 3. Dresden, Germany.

Carlquist S. 1977. Wood anatomy of Onagraceae - additional species and concepts. Annals of the Missouri Botanical Garden 64: 627-637.

Cavin L, Mountford PE, Peterken GF, Jump AS. 2013. Extreme drought alters competitive dominance within and between tree species in a mixed forest stand. Functional Ecology 27: 1424-1435.

Chenlemuge T, Schuldt B, Dulamsuren C, Hertel D, Leuschner C, Hauck M. 2014. Stem increment and hydraulic architecture of a boreal conifer (Larix sibirica) under contrasting macroclimates. Trees, doi: 10.1007/s00468-014-1131-x.

Dittmar C, Zech W, Elling W. 2003. Growth variations of Common beech (Fagus sylvatica L.) under different climatic and environmental conditions in Europe - A dendroecological study. Forest Ecology and Management 173: 63-78.

Drobyshev I, Övergaard R, Saygin I, Niklasson M, Hickler T, Karlsson M, Sykes MT. 2010. Masting behaviour and dendrochronology of European beech (Fagus sylvatica L.) in southern Sweden. Forest Ecology and Management 259: 2160-2171.

Fonti P, García-González I. 2008. Earlywood vessel size of oak as a potential proxy for spring precipitation in mesic sites. Journal of Biogeography 35: 2249-2257.

Fonti P, Heller O, Cherubini P, Rigling A, Arend M. 2013. Wood anatomical responses of oak saplings exposed to air warming and soil drought. Plant Biology 15: 210-219.

Härdtle W, Niemeyer T, Assmann T, Aulinger A, Fichtner A. Lang A, Leuschner C, Neuwirth B, Pfister L, Quante M, Ries C, Shuldt A, Oheimb G. 2013. Climatic responses of tree-ring width and $\delta 13 \mathrm{C}$ signatures of sessile oak (Quercus petraea Liebl.) on soils with contrasting water supply. Plant Ecology 214: 1147-1156.

Hertel D, Strecker T, Müller-Haubold H, Leuschner C. 2013. Fine root biomass and dynamics in beech forests across a precipitation gradient - is optimal resource partitioning theory applicable to water-limited mature trees? Journal of Ecology 101: 1183-1200. 
Hilton GM, Packham JR. 2003. Variation in the masting of common beech (Fagus sylvatica L.) in northern Europe over two centuries (1800-2001). Forestry 76: 319-328.

Jump AS, Hunt JM, Penuelas J. 2006. Rapid climate change-related growth decline at the southern range edge of Fagus sylvatica. Global Change Biology 12: 2163-2174.

Karpavicius J, Vitas A. 2006. Influence of environmental and climatic factors on the radial growht of European ash (Fraxinus excelsior L.). Ekologija 1: 1-9.

Köcher P, Gebauer T, Horna V, Leuschner C. 2009. Leaf water status and stem xylem flux in relation to soil drought in five temperate broad-leaved tree species with contrasting water use strategies. Annals of Forest Science 66: 101.

Köcher P, Horna V, Leuschner C. 2012. Environmental control of daily stem growth patterns in five temperate broad-leaved tree species. Tree Physiology 32: 1021-1032.

Lens F, Luteyn JL, Smets E, Jansen S. 2004. Ecological trends in the wood anatomy of Vaccinioideae (Ericaceae s.l.). Flora 199: 309-319.

Leuschner C, Backes K, Hertel D, Schipka F, Schmitt U, Terborg O, Runge M. 2001. Drought responses at leaf, stem and fine root levels of competitive Fagus sylvatica L. and Quercus petraea (Matt.) Liebl. trees in dry and wet years. Forest Ecology and Management 149: 33-46.

Mainiero R, Kazda M. 2006. Depth-related fine root dynamics of Fagus sylvatica during exceptional drought. Forest Ecology and Management 237: 135-142 .

Manion PD. 2003. Evolution of conepts in forest Pathology. Phytopathology 93: 1052-1055.

Meier IC, Leuschner C. 2008. Leaf size and leaf area index in Fagus sylvatica Forests: Competing effects of precipitation, temperature, and nitrogen availability. Ecosystems 11: 655-669.

Mette T, Dolos K, Meinardus C, Bräuning A, Reineking B, Blaschke M, Pretzsch H, Beierkuhnlein C, Gohlke A, Wellstein C. 2013. Climate turning point for beech and oak under climate change in Central Europe. Ecosphere 4: 1-19.

Müller-Haubold H, Hertel D, Seidel D, Knutzen F, Leuschner C. 2013. Climate responses of aboveground productivity and allocation in Fagus sylvatica: A transect study in mature forests. Ecosystems 16: 1498-1516.

Müller-Haubold H. 2014. Climate response of above and belowground productivity and allocation in European beech. Dissertation zur Erlangung des mathematischnaturwissenschaftlichen Doktorgrades der Georg-August-Universität Göttingen.

Overgaard R, Gemmel P, Karlsson M. 2007. Effects of weather conditions on mast year frequency in beech (Fagus sylvatica L.) in Sweden. Forestry 80: 555-565. 
Pautasso M, Aas G, Queloz V, Holdenrieder O. 2013. European ash 8Fraxinus excelsior) dieback - A conservation biology challenge. Biological conservation 158: 37-49.

Piovesan G, Adams JM. 2001. Masting behaviour in beech: linking reproduction and climatic variation.Canadian Journal of Botany 79: 1039-1047.

Pretzsch H, Schütze G. 2005. Cron allometry and growing space efficiency of Norway spruce (Picea abies [L.] Karst.) and European beech (Fagus sylvatica L.) in pure and mixed stands. Plant Biology 7: 628-639.

Pretzsch H, Biber P, Schptze G, Uhl E, Rötzer T. 2014. Forest stand growth dydnamics in Central Europe have accelerated since 1870. Nature Communications 5: 4967.

Roloff A, Schütt P. 2006. Enzyklopädie der Holzgewächse, Handbuch und Atlas der Dendrologie. Ecomed Biowissenschaften, Einbändige Sonderausgabe ersch. U.d.T.: Enzyklopädie der Sträucher Edn. Landsberg am Lech.

Scharnweber T, Manthey M, Criegee C, Bauwe A, Schröder A, Wilmking M. 2011. Drought matters - Declining precipitation influences growth of Fagus sylvatica L. and Quercus robur L. in north-eastern Germany. Forest Ecology and Management 262: 947-961.

Scherrer D, Bader KFB, Körner C. 2011. Drought-sensitivity ranking of deciduous tree species based on thermal imaging of forest canopies. Agriculture and Forest Meteorology 151: 1632-1640.

Schmidt W. 2006. Temporal variation in beech masting (Fagus sylvatica L.) in a limestone beech forest (1981- 2004). Allgemeine Forst- und Jagdzeitung 177: 9-19.

Schröter M, Härdtle W, Oheimb G. 2012. Crown plasticity and neighborhood interactions of European beech (Fagus sylvatica L.) in an old-growth forest. European Journal of Forest Research 131: 787-798.

Sterck FJ, Zweifel R, Sass-Klaassen U, Chowdhury Q. 2008. Persisting soil drought reduces leaf specific conductivity in Scots pine (Pinus sylvestris) and pubescent oak (Quercus pubescens). Tree Physiology 28: 529-536.

Yachi S, Loreau M. 1999. Biodiversity and ecosystem productivity in a fluctuating environment: the insurance hypothesis. PNAS 96: 1463-1468. 


\section{Summary}

Climate warming is predicted to increase the frequency and severity of droughts in Central Europe through increasing temperatures and regional changes in the precipitation regime. Fagus sylvatica (European beech), the most abundant tree species of Central Europe's natural forest vegetation and one of the key species in forestry, is thought to be particularly vulnerable to drought. As broad-leaved mixed forest stands in Central Europe are widely dominated by this species, the predicted climatic changes may have considerable impact on those forest ecosystems, what could lead to a shift in the competitive hierarchy and species composition of those forests. To evaluate how relevant changes may take shape, it is of great interest how co-occurring tree species react to drought compared to F. sylvatica and how mixed forest ecosystems are affected by drought in general.

In the frame of the present study F. sylvatica as well as the four co-occuring species Acer pseuoplatanus (sycamore maple), Acer platanoides (Norway maple), Quercus petraea (sessile oak) and Fraxinus excelsior (common ash) were examined with regard to their drought sensitivity. For this purpose wood cores of the corresponding species were collected at three stands along a precipitation gradient (590-685 mm). The sampled cores were used for dendrochronological and xylem anatomical analysis to investigate the species specific response and adaption to climatic changes in the period from 1951-2010. Furthermore, the neighborhood of any target tree was recorded, to evaluate possible effects of neighborhood diversity and identity on the drought resistance of the target tree. This was done to (I) investigate the impact of drought on increment of the five species, (II) examine the adaption processes in the hydraulic architecture of the stem xylem to changes in climate and (III) identify how tree characteristics and neighborhood composition affect the drought resistance of the investigated trees.

Increment of the investigated species was primarily determined by temperatures and precipitation amounts of the current and previous years spring and summer months. F. sylvatica was the only species showing growth decline since about 1980 at the driest stand. This growth decline was closely related to increasing temperatures and increasing drought intensity. Furthermore, F. sylvatica showed the strongest growth depression during extreme droughts and the frequency of corresponding growth depressions (negative pointer years) did increase during the end of the investigated period only in this species.

Climate response analysis showed that hydraulically-weighted mean vessel diameter $D_{\mathrm{h}}$ was determined by the same climate conditions as tree-ring width, leading to smaller vessels under increased aridity. However, this trend was overlain by a marked age/size effect that led to a 
significant increase of $D_{\mathrm{h}}$ in all species except $F$. sylvatica over the investigated period and as a result in an increase of the sapwood area-specific hydraulic conductivity $\left(K_{\mathrm{p}}\right)$. Despite the missing increase in $D_{\mathrm{h}}, F$. sylvatica was also able to increase its $K_{\mathrm{p}}$ through an increased vessel density (VD), reflecting a remarkably plasticity of the hydraulic architecture of this species. Yet, while $K_{\mathrm{ann}}$, the conductivity generated by annual ring growth, showed an even larger increase than $K_{\mathrm{p}}$ in the four other species, $K_{\mathrm{ann}}$ of $F$. sylvatica decreased in conjunction with the observed growth decline.

While the neighborhood diversity had no effect on the growth resilience to severe drought events, the proportion of $F$. sylvatica had a negative impact on resilience in some cases. Of greater importance for a high resilience was the size of the target tree. In all species growth resilience after two extreme drought events was negatively related to diameter at breast height (DBH). The higher sensitivity of large-diameter trees results in a shift in intra- as well as interspecific population structure with smaller, less competitive trees surpassing larger dominant trees in radial increment in the decades after a severe drought. This pattern was clearest in F. sylvatica and enabled small trees at the driest stand to even increase their BAI since 1980, contrary to the general trend.

Those results indicate that extreme drought events represent an important structuring force in Central European mixed forests that trigger dynamic change in the population structure of the species and also in species composition. Despite its high plasticity, F. sylvatica was the species strongest affected by drought and it can be expected that this species will lose at least some of its competitive strength in the course of climate warming. 


\section{Acknowledgments}

First of all, I would like to thank Prof. Dr. Christoph Leuschner for providing me an interesting and sometimes challenging research topic - many thanks for the constant support and the great interest in my work.

Special thanks go to Prof. Markus Hauck for his help and support throughout the last years.

I thank Dr. Choimaa Dulamsuren for introducing me into the fascinating world of dendrochronology.

I also want to thank Dr. Bernhard Schuldt for sharing his knowledge about everything regarding the water transport system of trees and his great support with the second paper.

I like to thank the DFG for funding, as well as the DBU and the Biosphere Reserve Karstlandschaft Südharz for giving me their permission to take samples in their forest stands.

I thank Samuel Schleich, Carola Feßel and Jan-Hendrik Schneider for their help in the field and analyzing data.

Thank you to Dr. Stefan Meyer, who was a really big help in acquiring the study sites.

I want to thank Dr. Heinz Coners, who made my work much easier by providing easy solutions for the data analysis.

I am grateful to all my colleague PhD students for the fruitful discussions and the less fruitful, but equally important fooling around during coffee breaks.

I want to thank my parents, who enabled my education through their unlimited support over the last years

I am exceptionally grateful to my wife Nicole for her never ending support and encouragement and her unconditional love over the last years. Without you, finishing this work would have been incomparably harder.

Finally, I want to thank my daughter Ziva just for being there. Waking up in the morning, seeing you smiling at me made my life so much more complete. 



\section{Declaration of originality and certificate of ownership}

I, Jorma Zimmermann, hereby declare that I am the sole author of this dissertation entitled 'THE IMPACT OF DROUGHT AND CLIMATE WARMING ON CENTRAL EUROPEAN BROAD-LEAVED MIXED FORESTS'. All references and data sources that were used in the dissertation have been appropriately acknowledged. I furthermore declare that this work has not been submitted elsewhere in any form as part of another dissertation procedure.

Göttingen, August 25, 2015

(Jorma Zimmermann) 